LA--921 9-MS

DE82 015894

\title{
Floristic Composition and Plant Succession on Near-Surface Radioactive- - Waste-Disposal Facilities in the Los Alamos National Laboratory
}

\author{
Gail D. Tierney \\ Teraiene S. Foxx
}

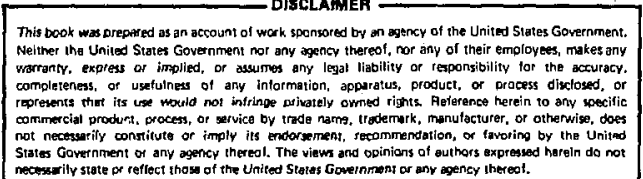

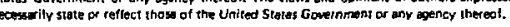

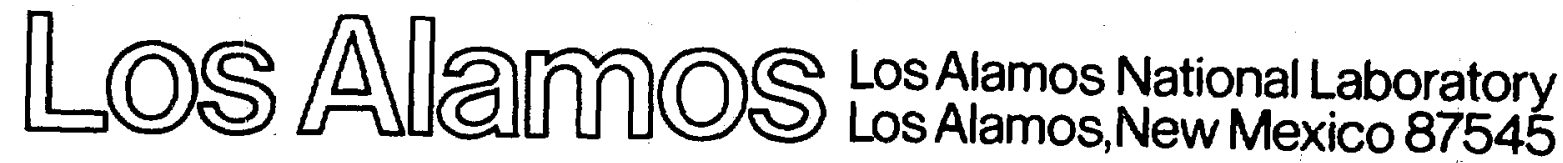




\title{
FLORISTIC COMPOSITION AND PLANT SUCCESSION ON NEAR- SURFACE RADIOACTIVE-WASTE-DISPOSAL FACILITIES IN THE LOS ALAMOS NATIONAL LABORATORY
}

by

\author{
Gail D. Tiemey and Teralene S. Foxx
}

\begin{abstract}
Since 1946, low-level radioactive waste has been buried in shallow landfills within the confines of the Los Alumos National Laboratory. Five of these sites were studied for plant composition and successional patterns by reconnaissance and vegetation mapping.

The data show a slow rate of recovery for all sites, regardless of age, in both the piñon-juniper and ponderosa pine communities. The sites are not comparable in succession or composition because of location and previous land use. The two oldest sites have the highest species diversity and the only mature trees.

All sites allowed to revegetate naturally tend to be colonized by the same species that originally surrounded the sites. Sites on historic fields are colonized by the old field flora, whereas those in areas disturbed only by grazing are revegetated by the local native flora.
\end{abstract}

\section{INTRODUCTION}

Recently proposed Environmental Protection Agency (EPA) and Nuclear Regulatory Commission (NRC) standards for disposal of uranium mill tailings and low-level nuclear waste would require reclamation procedures that assure the integrity of the waste burial for at least 1000 years. ${ }^{1,2}$ The need for assurance over such a long time forces designers of waste burials to consider the processes of natural plant succession at the proposed sites and to determine the potential effects of succession on the capabilities of cover and barriers to retain the wastes. However, little information has been compiled on: the colonizing plant species and successional patterns on such sites. ${ }^{3}$ Information on successional pat-: terns is important for developing biobarriers against such natural phenomena as deep root intrusion, as succession proceeds from shallow-rooted annuals to deeply rooted shrubs and trees, or the attraction of rodents, and consequently their burrows, by inadvertent provision of a preferred food source in reclamation seeding.

For the past $34 \mathrm{yr}$, low-level wastes have been buried in various aballow landfills within the confines of the Los Alamos National Laboratory. Neither the floristic composition nor mocewional patterns on these sites have been inveatigated, although extenaive geological and hydrological atudien have been made." 
Thus, an opportunity existed to study the natural processes of revegetation as well as to examine the course of succession on reseeded disposal facilities at a given location. During the summer of 1980, successional patterns and floristic composition of six individual sites at Los Alamos were studied. The degree of disturbence on these sites ranged from: (1) minimal (a undisturbed but imminent waste disposal site) and (2) recently disturbed sites, to (3) sites that have been closed for $34 \mathrm{yr}$.

The objective of the study was to compare plant species composition and diversity on accessible waste disposal sites in the Los Alamos National Laboratory properties by surveying the vegetation of each site during a one-season reconnaisance, and by using previuus vegetation studies of the plant communities of the Los Aiamos National Environmental Research Park as controls. ${ }^{6,7}$ Although areas immediately outside of the waste sites were also examined, in most cases, these areas are continuously disturbed and consequently of little value as control areas.

Vegetation on each site was surveyed to determine the floristic composition with respect to the following factors: duration since the disposal area had last been disturbed; individual site factors, such as natural topography or settling and slump; previous utilization and vegetation of the site; and the relative importance of the observed seral species. Cores of the largest trees were taken from the oldest sites (B and F). The dendrochronology of these trees is included in the site description (Sections V and VII).

Only five disposal areas were considered in the original plans of this project. A sixth study area was added when we were notified that it was to be opened as an experimental waste disposal area in the spring of 1981. Although the data for this sixth site are not as detailed as the previous five, it will provide a base line so that succession can be monitored in the years following its closure.

Because successional studies are by nature long term, we have furnished detailed vegetation maps and descriptions of procedures followed for each site so that comparative studies can be made in the future. Duration of our field work was one season (1980). The total time alloted to this project, from the initial field work to completion of a draft of this report, was 45 days.

\section{DESCRIPTION OF STUDY AREA}

The waste sites studied are within the confines of the Los Alamos National Laboratory. The Laboratory is located in Los Alarros County, approximately 35 miles west of Santa Fe, New Mexico.

The Laboratory is situated on the Pajarito Plateau, which is a dissected, table-like extension of the eastern flank of the Jemez Mountains, the Sierra de Los Valles. The easternmost extension of the plateau consists of mesas and buttes, which are bounded on the east by the Rio Grande (Fig. 1). The elevational range of the Near-Surface Waste Disposal Sites is approximately 1963 to $2271 \mathrm{~m}$ (6438 to $7449 \mathrm{ft}$ ).

\section{A. Geology}

The plateau was formed from volcanism that began over 12 million years ago, but consisted mainly of two huge pyroclastic blasts that produced the Bandelier tuff about one million years ayo. Soils in the study area are derived mostly from the Tshirege member of the Bandelier tuff, which is Pleistocene in origin. They are thin, ranging from a few $\mathrm{cm}$ deep at the edges of the mesas to over $2 \mathrm{~m}(6 \mathrm{ft})$ deep on the inner portions of the mesas close to the mountains.

\section{B. Climate}

Climate is generally that of the semiarid continental mountain type. Average annual precipitation is 45 $\mathrm{cm}$ with $\mathbf{7 5 \%}$ of it falling during the months of May through October. The peak rainfall month is Auguist 


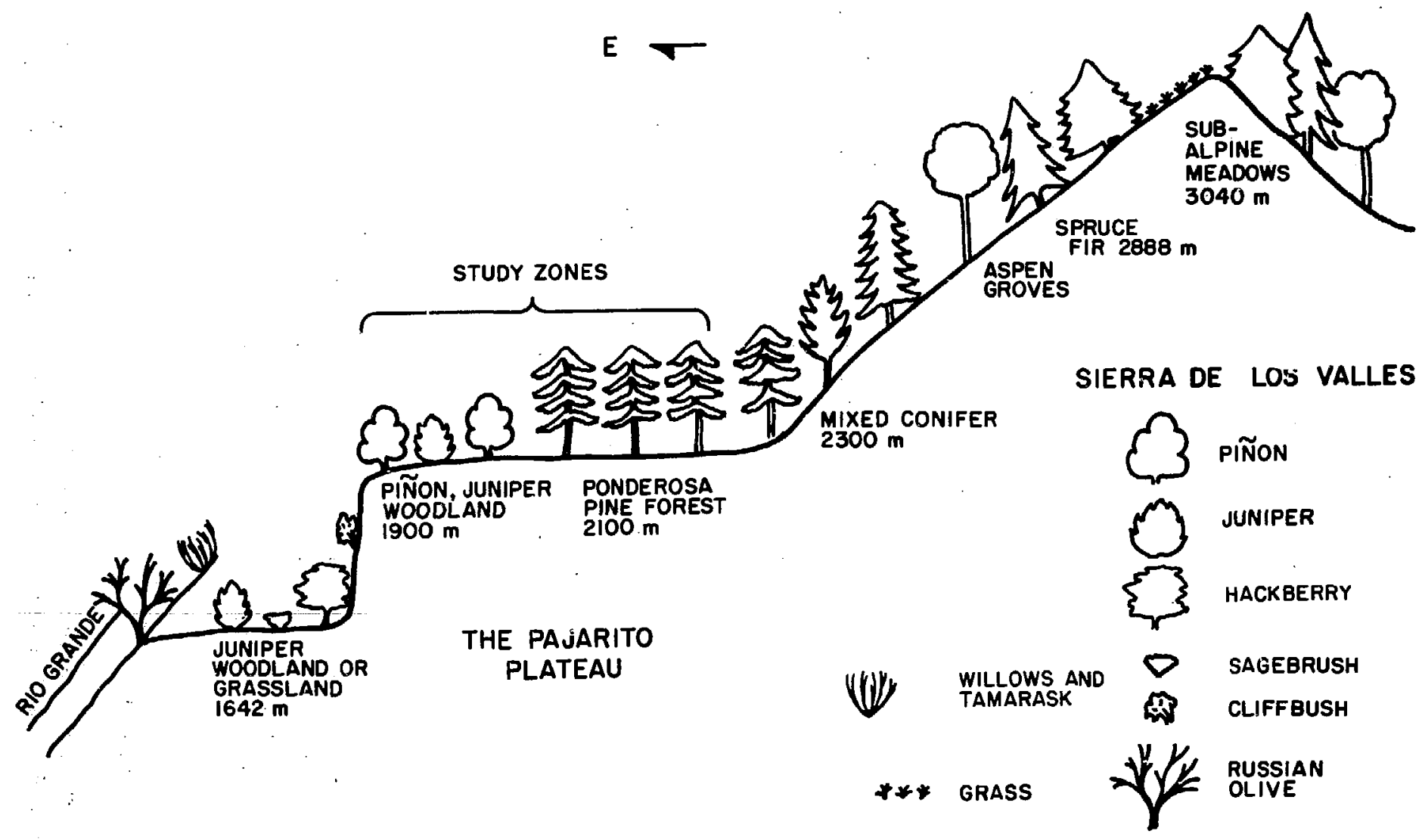

Fig. 1. Plant communities of the Pajarito Plateau and Sierra de Los Valles. 
with heavy thunderstorms occurring in the afternoon, and rapid runoff of rain water. Winter precipitation falls as snow with an average annual depth of $100 \mathrm{~cm}$ (40 in.).

Maximum daytime temperatures usually reach $32^{\circ} \mathrm{C}$ about 2 days per year. Freezes have been recorded in all months except July and August. Winters are gexerally mild, averaging only 18 days when the temperature stays below freezing. The mean humidity is $41 \%$, and winds are generally out of the south and less than $4 \mathrm{mph} 80 \%$ of the time. Local temperature and climate for 1980 was that of a mild wet winter; a cold, dry, and windy spring; and a hot dry summer with day and nighttime temperatures much higher than the norm. The expected July and August Mexican monsoon season was late in arriving and light in the delivery of moisture. In New Mexico, 1980 was generally considered a year of drought.

\section{Plant Communities}

Within the study area, two plant communities predominate: that of the ponderosa pine (Pinus ponderosa) and the piñon-juniper (Pinus edulis and Juniperus monosperma) (Fig. 1). The ponderosa pine extends over elevations of 2100 to $2300 \mathrm{~m}$ (6888 to $7544 \mathrm{ft}$ ) and occupies most of the western $1 / 3$ of the Laboratory. The piñon-juniper ranges over 1900 to $2100 \mathrm{~m}$ (6232 to $6888 \mathrm{ft}$ ) and occupies the eastern extensions of the plateau.

The ponderosa pine zone is characterized by nearly pure ponderosa pine stands, which range from doghair thickets to open stands. Much of this zone shows evidence of the extensive logging and fire suppression that took place during the early 1900 s. The understory is composed mostly of grasses, such as mountain muhly (Muhlenbergia montana), little blue stem (Andropogon scoparius), pine dropseed (Blepharoneuron tricolepis), and western wheatgrass (Agropyron smithil). The two most common shrubs are gambel's oak (Quercus gambelit) and bearberry (Arctostaphylos uva-ursi). Common forbs are pussytoes (Antennaria parvifolia) and Fremont's goosefoot (Chenopodium fremontii).

The piñon-juniper community is co-dominated by piñon and one-seed juniper. The most common shrubs are the oaks (Q. undulata and Quercus grisea), mountain mahagony (Cercocarpus montanus), wormwood (Artemisia ludoviciana), skunkbush sumac (Rhus trilobata), and the wax current (Ribes cereum). Grasses most often recorded are blue grama (Bouteloua gracilis), needle and thread grass (Stipa comata), galleta (Hilaria jamesii), and ring muhly (Muhlenbergia torreyi). Among the many common native forbs are bitterweed (Hymenoxys argentea), white ragweed (Hymenopappus filifolius) and leafy golder aster (Chrysopsis villosa). ${ }^{6}$

\section{History}

Prehistorically, the lower elevational zones of the Pajarito Plateau were inhabited by Pueblo III peoples from about 1150 to $1500 \mathrm{AD}$. Historic agriculture began in the higher regions of the plateau in the late 1800s and was continued until 1942 when homesteads were taken over for the Manhattan Project. The ponderosa pine zones were also subjected to heavy logging from near the turn of the century until the mid-1940s. In addition, much acreage has been cleared for buildings and parking lots needed to support Laboratory activities.

\section{FIELD PROCEDURES}

During the summer of 1980 , five low-level waste disposal sites within the confines of the Laboratory were surveyed to obtain (1) the major floristic elements of each site and (2) successional information as 
related to previous history and length of time from site closure. Location, history, and topography of each site is discussed separately within the body of this report (Sections IV through IX).

Sites varied considerably in shape and total acreage. Each site was measured along the outer perimeter, when possible, and transects were placed so that vegetation differences because of topography would be seen. Because particulars used in the methodology for each site may differ, they are discussed individually in each site section. In general, the following field procedures were used.

Initially each site was reconnoitered and a species list compiled. Transects were positioned by three criteria: (1) that they be easily relocated for future ieference, (2) that they show up maximum diversity as well as homogeneity of the vegetation, and (3) that a minimum of $90 \%$ of the previously noted species be intercepted. In all cases, we had less than a $10 \%$ error in species composition, and never were more than four transects necessary to obtain this small degree of error. Transect lengths of each site were to the nearest 50-m (164-ft) mark before reaching the end of the site opposite the starting point. All vegetation intercepting the meter tape was recorded. Information was noted in 1-m (3-ft) segments so that frequency could be calculated. From this information and species composition, an abundance factor was determined as a measure of density.

Every $10 \mathrm{~m}$ (32.8 ft), a meter quadrat was laid down and the total percentage foliage cover for each species was visually estimated with the aid of a $10-\mathrm{cm}(2.5-\mathrm{in}$.) quadrat. From these data, per cent foliage cover and frequencies of species were determined. Adjacent to three of the waste disposal areas (F, B, and E), on the side that seemed least disturbed, the same type of transect was run for reference and control. This procedure was impractical at the other sites.

Vegetation maps of the three smaller disposal areas (F, B, and E) were drawn in detail on graph paper with each large square of the paper representing $1.5-$ to $2.0-\mathrm{m}(4.9-$ to $6.6-\mathrm{ft})$ quadrats. Every important species in the square was represented by a symbol. ${ }^{9}$ This method provided a fine resolution for small heterogeneous sites. In order to aid the burrowing animal studies, the stirvey of $G$ area was added at a later date, and a vegetation map designed to be transferred to "MAPPER" (a computer graphics program) was produced. Information from the original map of areas $B$ and $E$ was modified and coded for the "MAPPER." These maps are found as figures with the site description.

Collecting plants from the waste sites was prohibited. We relied on our previous knowledge of the Plateau flora and collected outside the site when necessary. Unknown rosettes and leaves of seedlings were drawn and given a symbol so that they could be identified later when the plant matured. In some cases, that is, sweet clover (Melilotus spp.), grasshopper grazing was so severe that the floral parts never became available for specific identification, and we are aware of three different species of Melliotus in the area. Furthermore, the expected late summer rains and the responding late summer flowering season never materialized during the 1980 season.

The need arose for some information on the root depth of a few of the more common forbs of the area. We excavated 24 different specimens of 3 different species near Area F and measured their root depth (Appendix A). The need for this type of information on plants that colonize waste disposal sites is becoming more evident, but because the process is time consuming, it was deferred to a later and separate project.

Dendrochronological cores were taken from mature trees. These grew only on the two sites with the oldest closure dates, areas B and F. Several small, medium, and large tres were also mensured for diameter at breast height (dbh) and foliage cover.

Wishing to stay within our time frame, we found it necessary to eliminate the mapping of one site. We chose to disregard area $\mathbf{C}$ because its homogeneity was evident from the transects.

The following is a summary of near-surface waste disposal sites surveyed, their duration of use, and time of closure (Fig. 2).

Area B: Located on DP road. It is probably the first common burial ground at the Laboratory. A series of pits were used from 1944 to 1948 . Closed for 32 yr. 


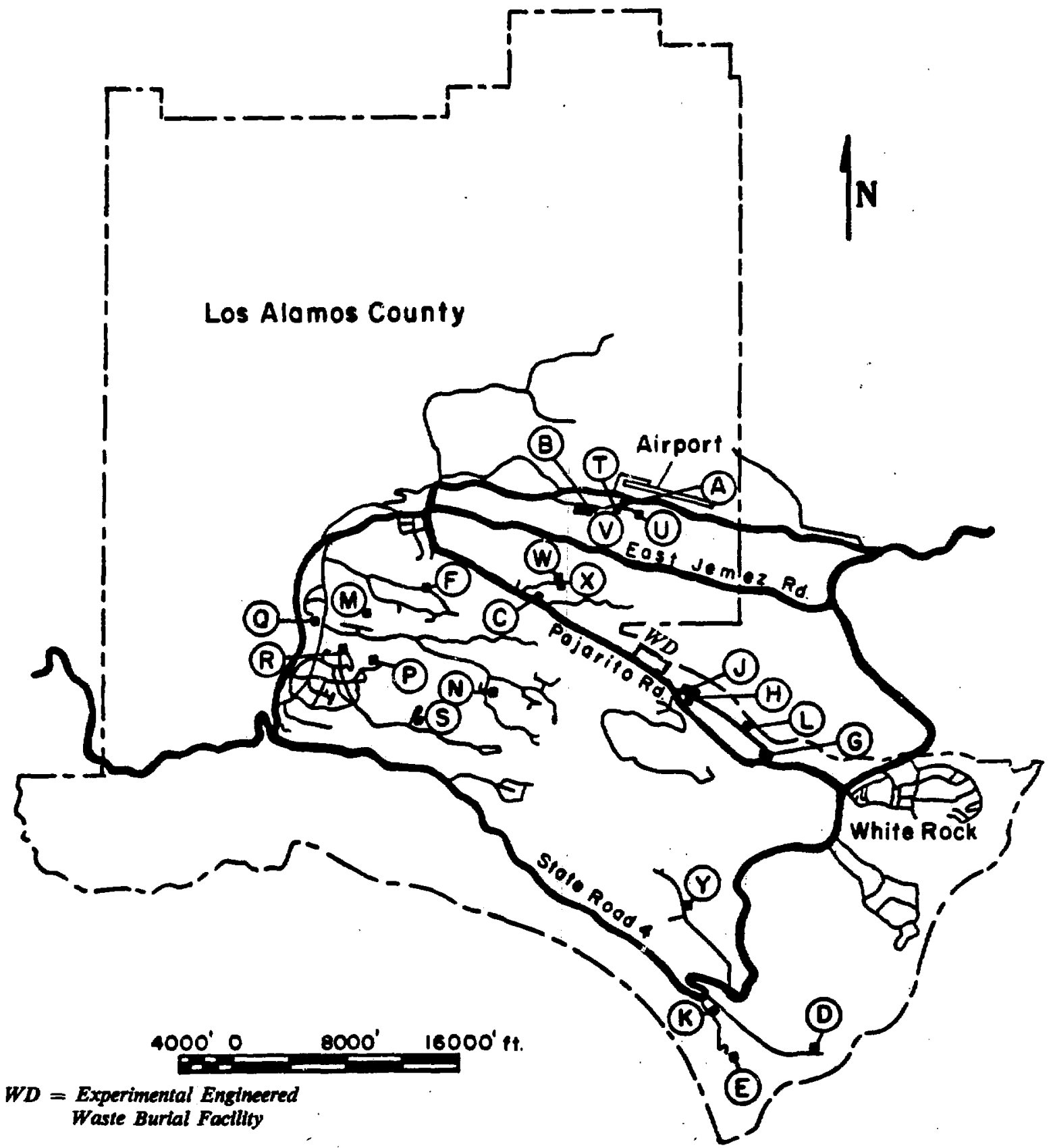

Fis. 2. Map of materials disposal areas. 
Area C: Located north of Pajarito Road near TA-55 and TA-50. It was used from 1948 to 1974. The portion surveyed, however, was closed in 1963 (17 yr). A plot in the western portion remained open until $1974(6 \mathrm{yr})$ and was not within the survey.

Area E: Located near TA-33. The area includes an underground chamber destroyed in 1950 and six pits that were abandoned in 1962 . Closed for $18 \mathrm{yr}$.

Area F: Located on Two Mile Mesa. This site was opened and closed in 1946, 34 yr ago.

Area G: Located on Mesa del Buey. Portions of $G_{1}$ were excavated in 1957 and closed in 1974 (7 yr). Other areas, designated as $G_{3}$, were used from 1974 to 1976 (closed for $4 \mathrm{yr}$ ).

Los Alamos Experimental Engineered Waste Burial Facility: Located off Pajarito road about 1/2 mile from the access road to area $G$. Site was undisturbed when surveyed for endangered species and vegetative composition.

\section{METHODS OF DATA ANALYSIS}

Importance values for observed plant species were calculated using techniques given in Phillips, ${ }^{10}$ and Kershaw." Importance value was obtained by adding relative abundance, relative dominance, and relative frequency and dividing by 3 ; this value combines these three variables into a convenient number for comparison. Plants can then be ranked as to those most dominant to those least common.

Relative abundance, dominance, and frequency were calculated in the following manner:

Relative abundance $=\frac{\text { Number of individuals of a species }}{\text { Total number of individuals of all species }} \times 100$

Rslative dominance $=\frac{\text { Total per cent cover of a species }}{\text { Total per cent cover of all species }} \times 100$

Relative frequency $=\frac{\text { Number of points of occurrence of a species }}{\text { Number points occurrence of all species }} \times 100$

Field taxonomic identifications were verified with several southwestern floras. ${ }^{12-14}$ If the plants were not identifiable to species because of growth stage, they were merely identified to genera. Information about life form, that is, annual, perennial, shrub, tree, place of origin, and native or introduced, was designated by using a concensus of floras and rangebooks. ${ }^{12-16}$

Trees in two sites, F and B, were cored with a standard 16-inch Swedish increment borer and rings were counted using a binocular microscope. Comparison was made with a chronology that has been developed for the Los Alamos area. ${ }^{17}$

\section{DESCRIPTION OF WASTE DISPOSAL AREA B}

\section{A. Location}

The surveyed portion of low-level waste burial area B is located on the south side of DP road, east of the County Trailer Storage Area, and weat of TA-21. Township and range are SE 1/2 sec. 15, T. 19N, R 6E, and SW 1/2 sec. 14, T. 19N., R6E. For the Laboratory coordinates, see Rogers.' This is only about $1 / 3$ of the total area of B site (Fig. 3). The other $2 / 3$ is weat of the arvey area, covered with asphak, and 


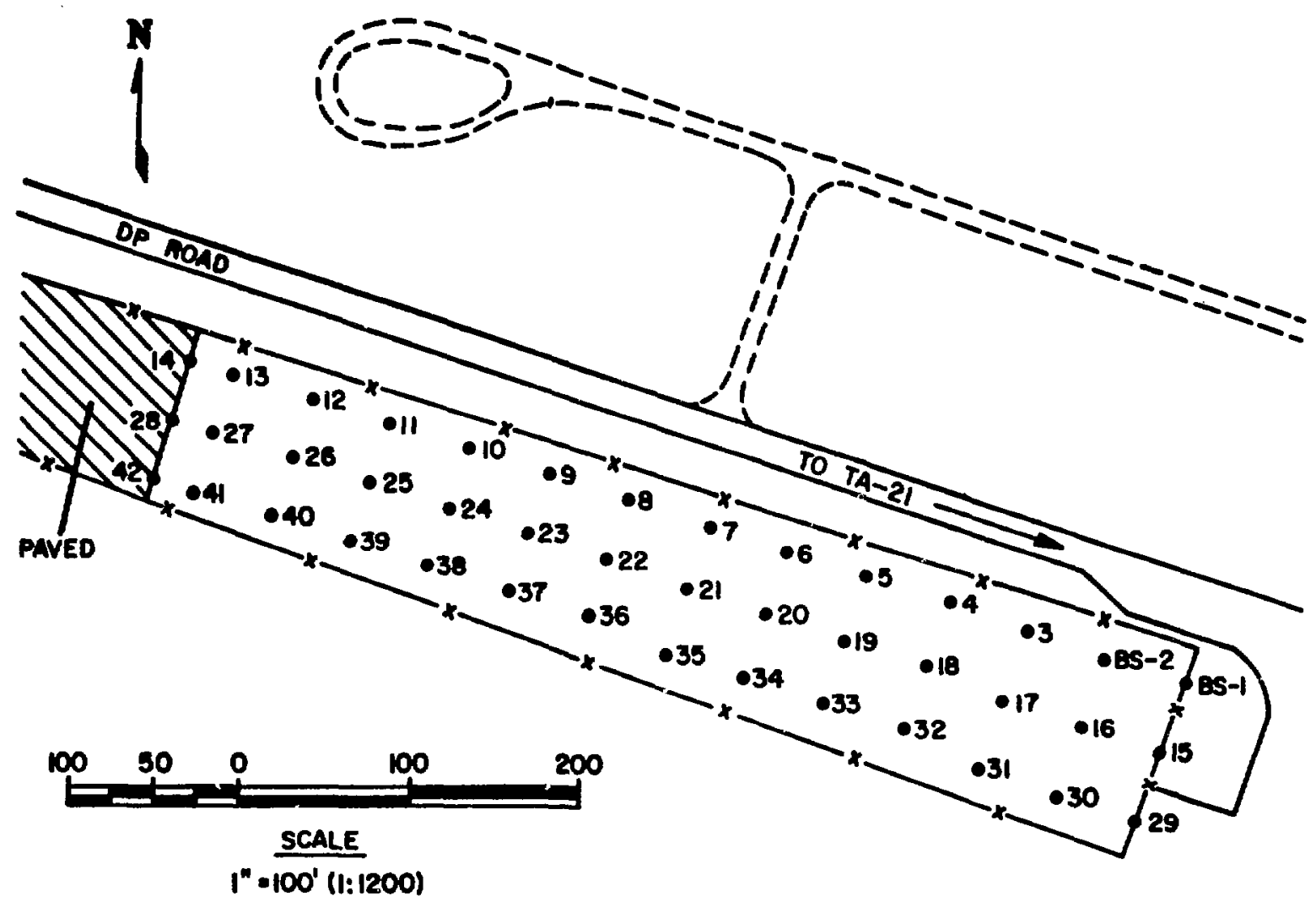

Fig. 3. Waste Disposal Site B Survey Area.

has been leased to the County as the privats trailer parking area mentioned above. The portion of area B surveyed for vegetation composition, the easternmost part, is separated from the other part by a chainlink fence with one gate on the east side. The approximate dimensions of the area we surveyed are: NE corner to SE corner, $49 \mathrm{~m}(160 \mathrm{ft})$; SE corner to SW corner, $223 \mathrm{~m}$ (731 ft); SW corner to NW corner, 38 $m(125 \mathrm{ft})$; and NW corner to NE corner, $226 \mathrm{~m}(741 \mathrm{ft})$. The area of the surveyed portion is approximately 0.98 ha $\left(9.8 \times 10^{3} \mathrm{~m}^{2}\right)$.

Area B is situated on what could reasonably be called Los Alamos Mesa because it shares the same mesa with the business district and residential area of the town. Elevation at the site is about $2182 \mathrm{~m}$ ( $7160 \mathrm{ft}$ ). The surrounding area of the site consists of asphalt to the west, a paved road to the north, and a

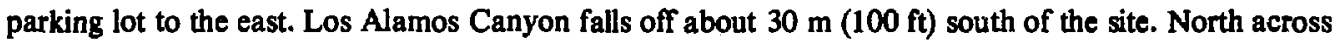
DP road and beyond about $90 \mathrm{~m}(295 \mathrm{ft})$ is a tributary of Los Alamos Canyon.

\section{B. Physical Description}

Area B.is entirely enclosed by an 8-foot-high chain-link fence with three strands of barbed wire on top. The only gate is on the east side and requires a key for admittance. The substrate of the site is of volcanic tuff and the soil layer was probably originally very shallow as tuff outcrops adjacent to the site on the south and east. The site slopes mainly to the south and a little towards the east. The eastern 1/2 portion of 
the site appears to be stable, whereas that of the western half has subsidence features; chunks of concrete are strewn on the NW corner, perhaps to retard erosion at the highest point of the site. A trench runs from iriside the SE fence corner almost to the SW corner.

\section{History}

The site of the waste disposal pit designated as area B was apparently outside of the confines of the agricultural areas that were established on Los Alamos Mesa in the early 1900s. From the 1930 aerial maps, the area appears to have been vegetated with stands of ponderosa pine, whereas the area east, presently DP site, was a portion of an agricultural field (Fig. 4). The area across the road and north of the site has also been cleared.

In 1942, a trailer park was located somewhat west of Area B. This park was for the Corp of Army Engineers personnel, their families, and construction workers, when Los Alamos was first being built into a wartime laboratory. Some trailers were in the regular park, whereas others were scattered down the mesa among tall pine trees. There were several outhouses scraped out of solid tuff both in the park and along the southern edge of the mesa.*

Area B was begun in 1944 and was the first shallow-land disposal site at Los Alamos. There is some question as to whether there was one major fill or several pits. Rogers ${ }^{3}$ concludes the latter is true. The site was decommissioned in 1948 and has lain fallow for $32 \mathrm{yr}$.

\section{Vegetation Overview}

Area B is situated in the ponderosa pine community. Although there is overlap, generally the site is almost equally divided into vegetationally distinct bsives. The eastern half of the site appears to have experienced the least amount of disturbance for the longest period of time. Here we find the largest ponderosa pines as well as thickets of Gambel's oak (Quercus gambelii). Blue grama and mountain muhly are the most important grasses. Common shrubby plants are on the northernmost side. Some of these are wormwood, sages (A. ludoviciana and Artemisia fridgida), and soapweed yucca (Yucca angustissima). Perennial forbs tend to be on the east side. A few representative ones are bitterweed (Hymenoxys argentea), fleabane (Erigeron divergens), greenthread (Thelesperma trifidum), and Colorado rubberweed or pinque (Hymenoxys richardsonii).

On the western side of the site, plants tend to be those associated with a less stable substrate. Common shrubs are chamisa (Chrysothamnus nauseosus) and false terragon (Artemisia dracunculus). The importance of the sweet clover (Melllotus sp.) on the site was visually less apparent because of grasshopper damage. Quantitatively, sweet clover was the most dominant plant on the entire site. Sweet clover prefers habitats of continual disturbance. Certain grasses with this preference, squirrel tail (Sitanion hystrix) and sand dropseed (Sporobolus cryptandrus), are also found mostly on the western side of the site. Along the northern fence are two large groups of skunk bush (Rhus trilobata) and mountain mahogany (Cercocarpus montamus).

Only outside the southern fence is the vegetation "natural" for the area. Near the SW corner there was a large thicket of wax current (Ribes cereum), whicii was dead during the summer of 1980 .

*Personal communication, Dec. 1980, William H. Doyle, Chief Inspector for the U.S. Corp of Army Engineers and Willard Kruger Construction Company of Los Alamos, Nov. 1942-1944. 


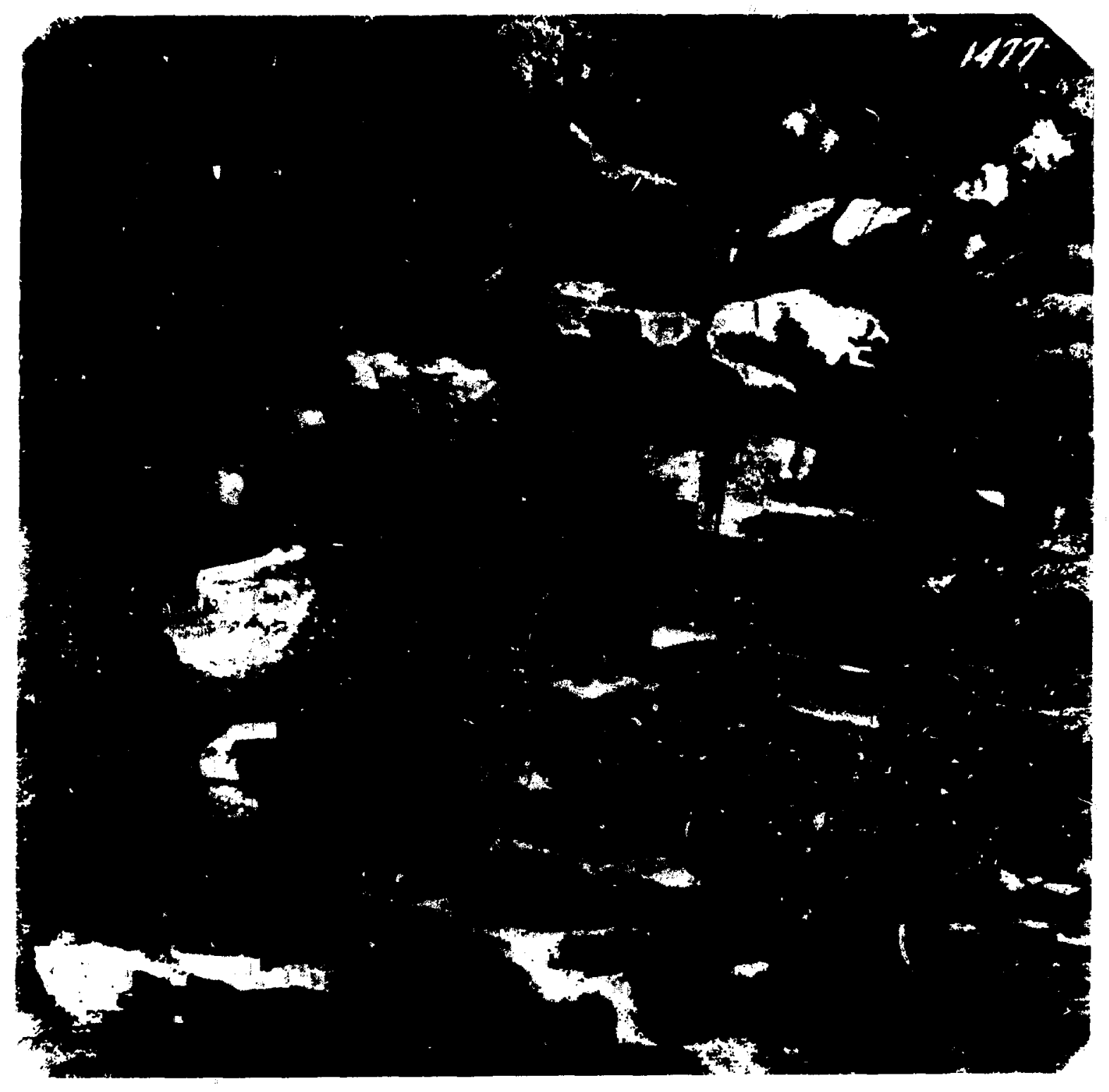

Fig. 4. Aerial photograph of Los Alamos townsite taken in 1935 showing A shley Pond (center of photo) and the extensive land areas used for dryland farming-B-site outlined (National Archives and Record Service, Washington, DC, Rio Grande Series No. 1477). Scale is 1:4680. 


\section{E. Procedures}

Area B was surveyed in late May and early June. Three 200-m (656-ft) transects were run from east to west dissecting the length of the plot. One transect was located in the middle of the site and the other two on either side ( $\mathrm{N}$ and $\mathrm{S}$ ) equally between middle transect and fence lines. The transects were used to determine species composition and density. Fifty-nine $1-\mathrm{m}^{2}$ plots were used to determine frequency and foliage cover.

The site had been previously marked into $7.5-\mathrm{m}$ (24.6-ft) grids for ease of measurement in small animal studies. These grids were $\mathrm{u}_{\mathrm{i}} \mathrm{ed}$ to map the vegetation on a $1.07-\mathrm{m}-(3.5 \mathrm{ft})$ mapping quadrat. Vegetation was classified as to the presence of sweet clover, native grass, introduced grass, forbs, or combinations of these (Fig. 5).

\section{F. Results}

A total of 59 species were recorded along the transects and within the plots (Appendix B). Of these 59 species, $20 \%$ were annuals, $10 \%$ biennials, $53 \%$ perennials, $10 \%$ shrubs, and $7 \%$ trees. Introduced species represented $22 \%$ of the total species found. Grasses made up $19 \%$ of the total species, forbs $64 \%$, shrubs $10 \%$, and trees $7 \%$. The sunflower family (Compositae) made up $36 \%$ of the species and the grass family (Graminac) 19\%. Eighteen families were represented.

Total foliage cover for the site is $25.8 \%$ foliage cover $/ \mathrm{m}^{2}$. Sweet clover, blue grama (Bouteloua gracilis), and wormwood (Artemisia ludoviciana) had the greatest percentage foliage cover. Importance values of selected species are shown in Table I. Transects running outside the fence on the south side showed mountain muhly to be the most important species. Total foliage cover outside the fence was $27.5 \%$ foliage cover $/ \mathrm{m}^{2}$.

The larger trees measured $17.5 \mathrm{~cm}(7 \mathrm{in}$.) at dbh. Smaller trees started at several feet tall. All were basically in the southeast corner near the south fence line. Dendrochronological samples show the larger trees to be between 16 and 18 yr old. One tree adjacent to the fence line (south side) was 27 yr old. Smaller trees averaged from 1.3 to $1.5 \mathrm{~m}(4-1 / 2$ to $5 \mathrm{ft})$ tall; they are no more than 4 or 5 yr old.

\section{G. Discussion}

Area $B$ is in an advanced stage of succession, particularly in the easiern end. It more closely resembles an open ponderosa forest. There is still a considerable amount of disturbance on the site where soil has caved in and rodents have burrowed, which perpetuates the environment for disturbed soil plants such as sweet clover and downy chess (Bromus tectorum). In the more stable areas, blue grama and mountain muhly are common.

The presence of two domesticated trees on the site, a mature peach and a Siberian elm, may be as a result of human habitation in the early 1940 s prior to utilization as a waste disposal site.

Site $B$ is, by far, the closest to climax of any of the waste sites. It has the largest number of species, the greatest species diversity, and the largest percentage of invasion by shrubs and trees.

\section{DESCRIPTION OF WASTE DISPOSAL AREA C}

\section{A. Location}

Area $C$ is located north of Pajarito rosd and south of TA-50. It is bordered on-the west by Pecos road, to the east by forest, and to the north by a shallow canyon. Townahip and range is E $1 / 2$ sec. 22, T., 19N, 
(a) Herbaceous vegetation.

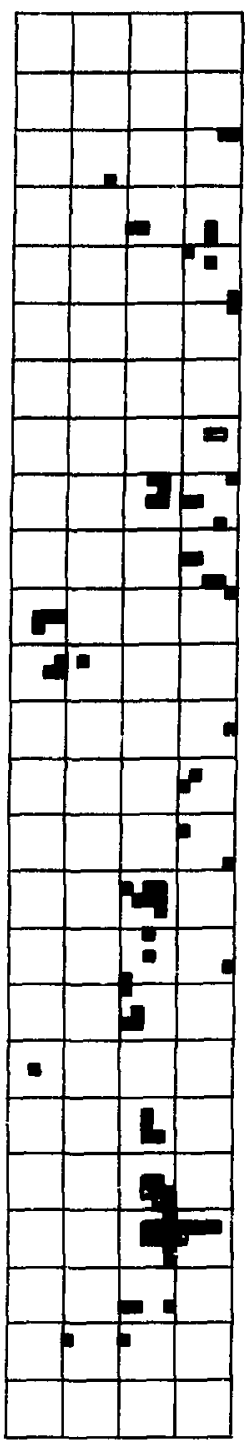

Disturbed GrassForbs

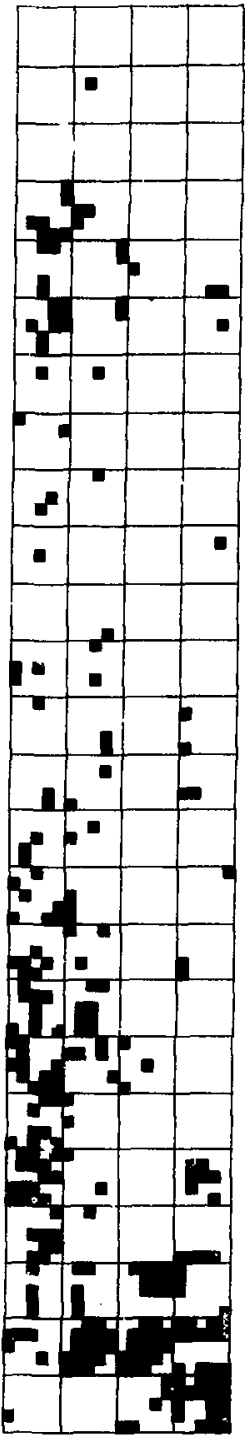

Native GrassForbs

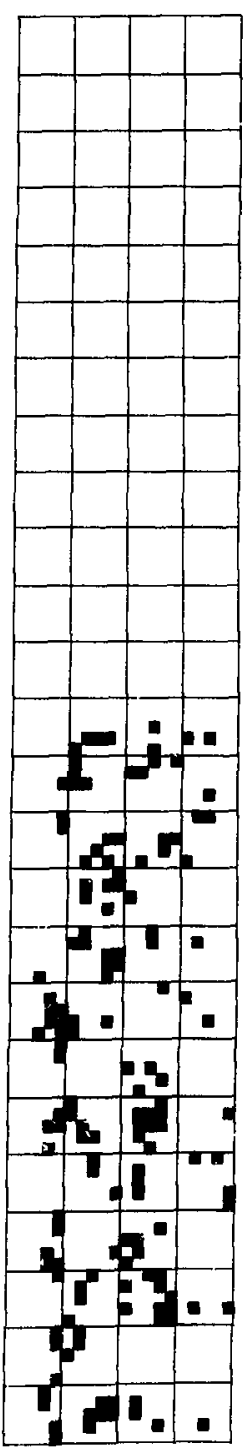

Melilotus-Forbs

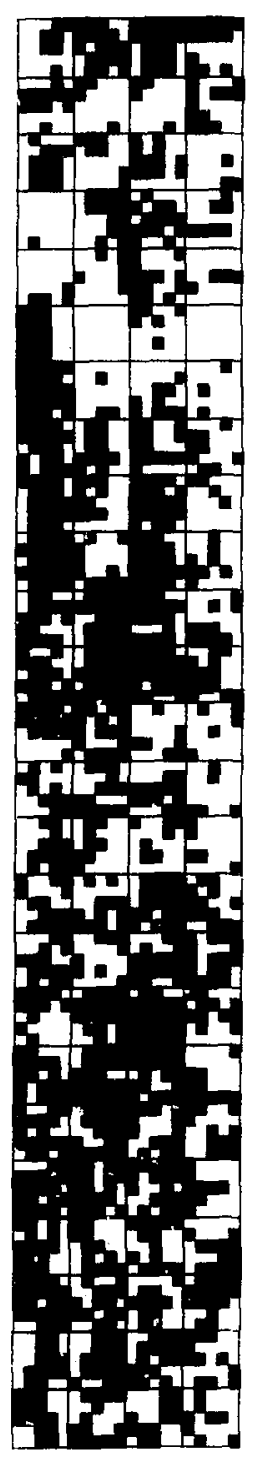

Forbs

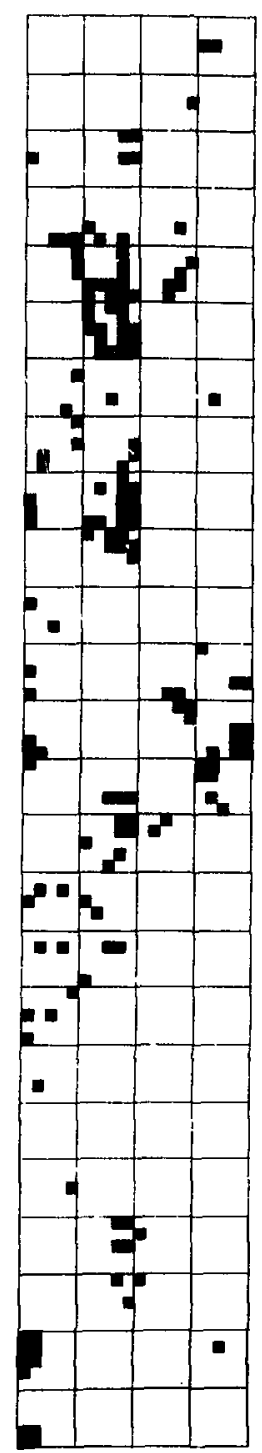

Disturbed Grass

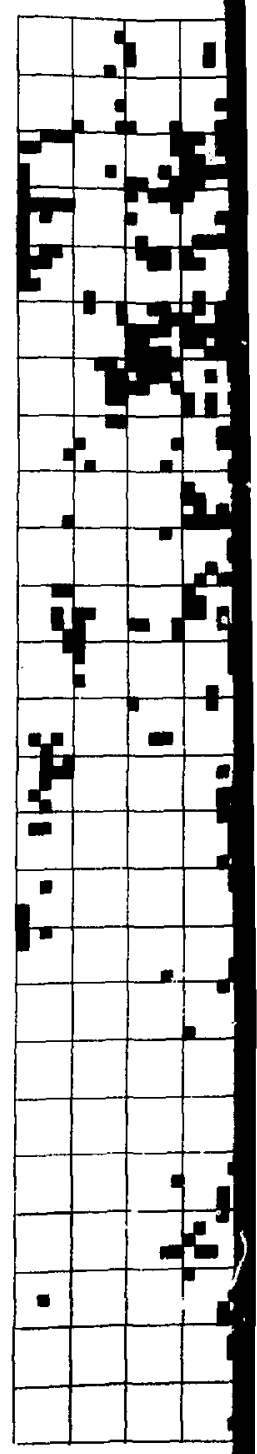

Native Grass

(b) Trees and shrubs.

Uת

28

$\square$

$0+4$
0<smiles>[3H]C1CCCC1</smiles>

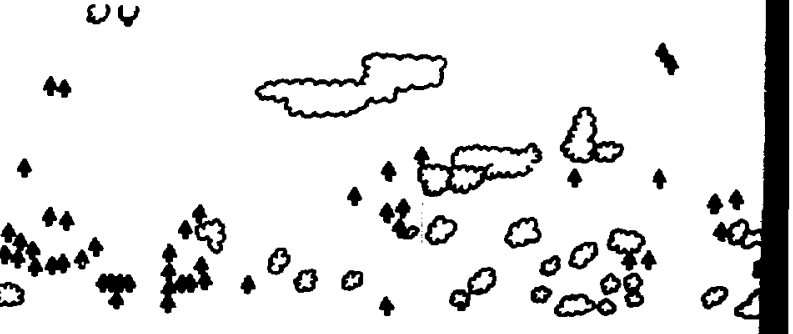

Fig. 5. Computerized vegetation map of waste dispasal site $B$. 
(a) Herbaceous vegetation.

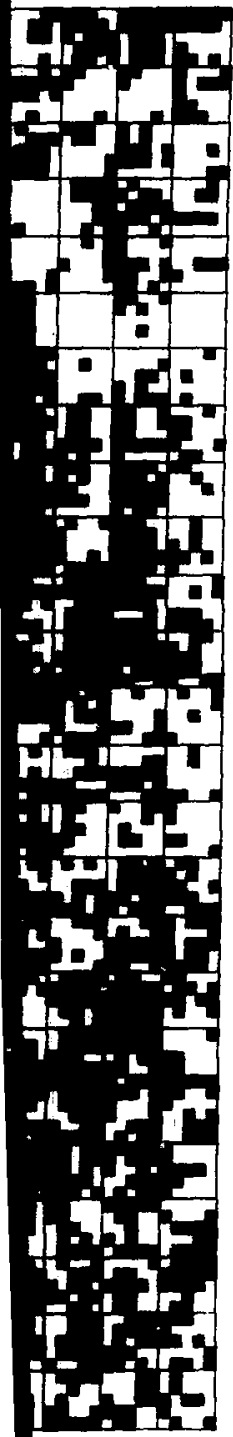

Forbs

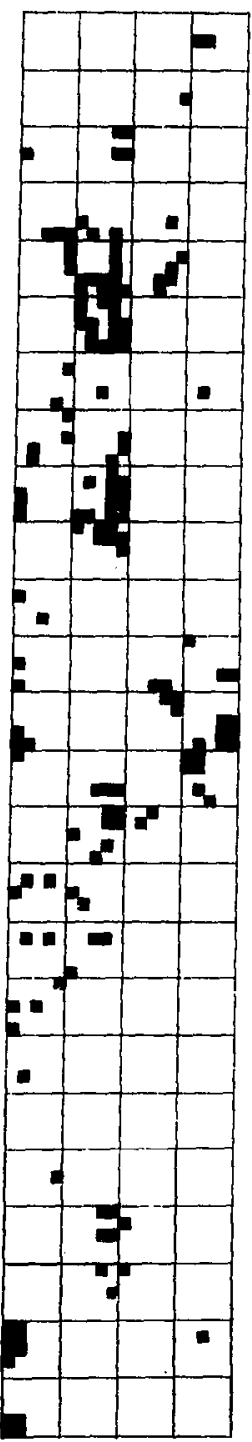

Disturbed Grass

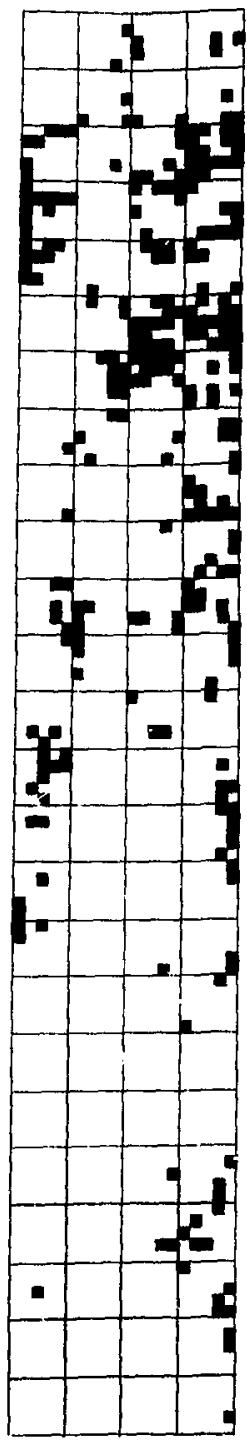

Native Grass

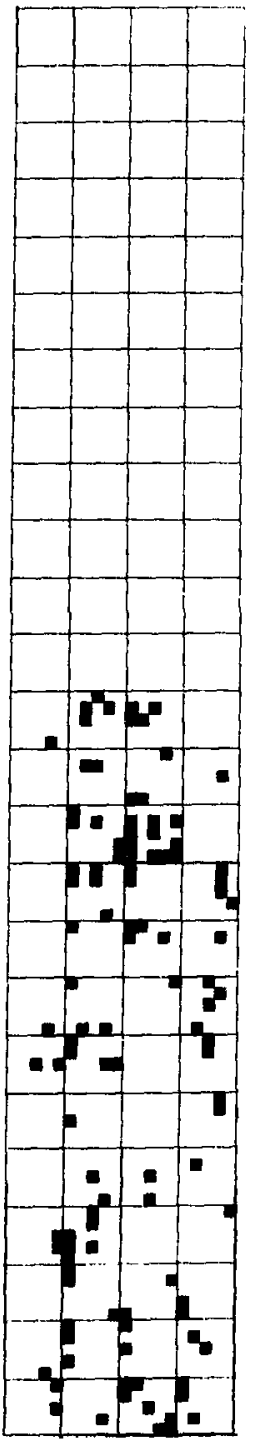

Melilotus

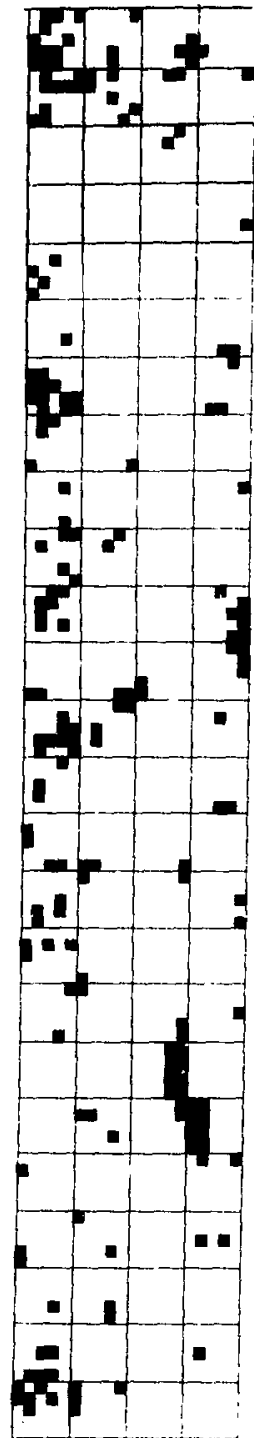

Bare Ground (b) Trees and shrubs.

we

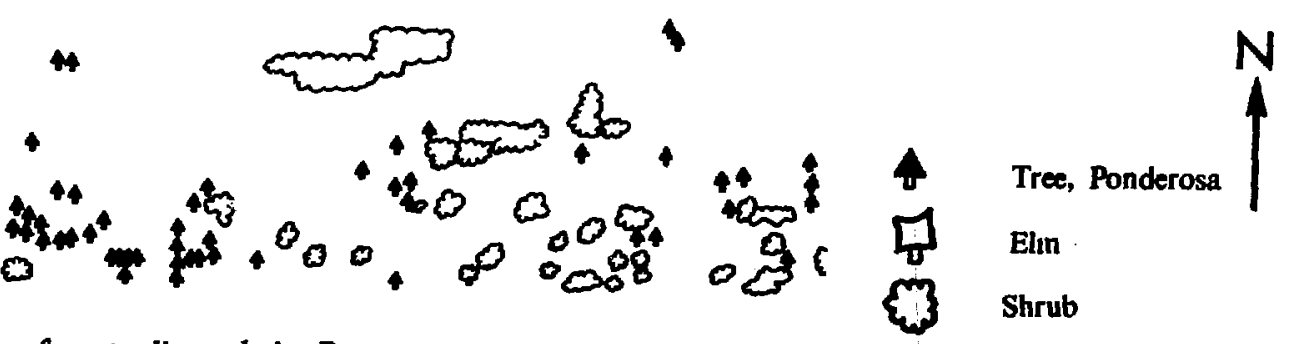

rap of waste disposal site $B$. 
TABLE I

\section{IMPORTANCE VALUES OF SELECTED SPECIES ON WASTE DISPOSAL SITE B}

\begin{tabular}{|c|c|c|}
\hline Species & Common Name & $\begin{array}{c}\text { Importance } \\
\text { Value }\end{array}$ \\
\hline Melilotus spp. & sweet clover & 12 \\
\hline Artemisia ludoviciana & wormwood & 10 \\
\hline Bouteloua gracilis & blue grama & 10 \\
\hline Sporobolus cryptandrus & sand dropseed & 7 \\
\hline Yucca angustissima & yucca & 6 \\
\hline Artemisia frigida & estafiata & 4 \\
\hline Artemisia dracunculus & false terragon & 4 \\
\hline Artemisia carruthii & wormwood & 4 \\
\hline Sitanion hystrix & squirreltail & 4 \\
\hline Thelesperma trifidum & green thread & 3 \\
\hline Tragopogon dubius & goatsbeard & 3 \\
\hline Verbascum thapsus & mullein & 3 \\
\hline Muhlenbergia montana & mountain muhly & 3 \\
\hline Bromus tectorum & downy chess & 2 \\
\hline Bromus spp. & brome & 2 \\
\hline Aristida divaricata & poverty 3-awn & 2 \\
\hline Gutierrezia microcephala & snakeweed & 2 \\
\hline Erodium cicutarium & cranesbill & 2 \\
\hline Plnus ponderosa & ponderosa pine & 2 \\
\hline Cryptantha jamesii & hidden flower & 1 \\
\hline Oenotherc spp. & evening primrose & 1 \\
\hline Gaura soccinea & scarlet gaura & 1 \\
\hline Hymencxys richardsonii & pinque & 1 \\
\hline Chrysopsis villosa & leafy golden aster & 1 \\
\hline Circium spp. & thistle & 0.8 \\
\hline Erigeron divergens & fleabane daișy & 0.8 \\
\hline Hymenopappus filifolius & yellow ragweed & 0.8 \\
\hline Fallugia paradoxa & Apache plume & 0.8 \\
\hline Quercus gambelii & Gambel's oak & 0.8 \\
\hline Lithospermum spp. & puccoon & 0.7 \\
\hline Poa spp. & bluegrass & 0.4 \\
\hline Penstemon spp. & beards tongue & 0.4 \\
\hline Kochia scoparia & summer cypress & 0.2 \\
\hline Grindelia aphanactis & gum weed & 0.2 \\
\hline Lactuca spp. & prickly lettuce & 0.2 \\
\hline Blepharoneuron tricolepis & pine dropseed & 0.2 \\
\hline Stipa comata & needle grass & 0.2 \\
\hline Plantago purshii & woolly Indian wheat & 0.2 \\
\hline Castilleja integra & Indian paintbrush & 0.2 \\
\hline Salsóla kali & Russian thistle & 0.1 \\
\hline Eriogonum spp. & buckwheat & 0.0008 \\
\hline
\end{tabular}


R6E. For Laboratory coordinatss, see Rogers. ${ }^{3}$ The entire acreage of $C$ area is $47.7 \mathrm{~m}^{2}$ (4.7 ha). We surveyed about $2 / 3$ of this site or approximately $3.2 \times 10^{4} \mathrm{~m}^{2}(3.2 \mathrm{ha})$.

\section{B. Physical Description}

This site is situated on top of a mesa (unnamed), towards its northern side, at an elevation of about $2206 \mathrm{~m}$ (7240 ft). Base rock is of volcanic tuff and, according to a 1963 USGS report, ${ }^{18}$ the soils are 1 to $1.5 \mathrm{~m}(3$ to $5 \mathrm{ft}$ ) deep. The site slopes northeast toward Ten Site Canyon, a tributary of Mortandad Canyon. The northernmost pits are considerably lower than southern pits, with slopes about $15^{\circ}$ to the north, while those to the south are almost level. An arroyo, or perhaps a planned drainage ditch, cuts to the north about the middle of the site. A hard-packed dirt road enters the site from Pajarito road and cuts toward the northeast corner (Fig. 6). Area $\mathrm{C}$ is fenced with a high chain-link fence with locked gates and is well marked.

\section{History}

Across Pajarito road and slightly to the west is a ruin of a log farm structure said to be part of the Garcia homestead. According to a Los Alamos resident of $33 \mathrm{yr},{ }^{*}$ this whole area was cleared of trees when he arrived in 1948: This is confirmed by aerial maps (Fig. 4) and an Atomic Energy Commission map showing agricultural areas (Fig. 7). The area was part of a dry farming field and pasture (Romero Homestead) previous to its conversion to building sites, roads, and a waste disposal site. This site was first put into operation as a shailow-land waste disposal site in 1948, and the areas surveyed were closed in 1963. The entire area was closed in 1974 (the final pit was outside the survey area).

\section{Vegetation Overview}

Area $\mathrm{C}$ is situated within the ponderosa pine community near the ecotone of the ponderosa pine/piñonjuniper communities. Except for the eastern and northern edges of the site, area $C$ is surrounded by buildings or roads. The eastern end is contiguous with a typical ponderosa pine forest with an understory of oak, little blue stem (Andropogon scoparius), mountain muhly, and various forbs. The northern end drops off into a disturbed canyon. Across Pajarito road to the sou th-southeast, vegetation is typical of fallow fields in our area, dominated by such species as false terragon (Artemisia dracunculus) and mullein (Verbascum thapsus). The vegetation of the entire area $\mathrm{C}$ waste disposal site is homogeneous, consisting mostly of false terragon, dropseed, and mullein.

\section{E. Procedures}

Area $\mathrm{C}$ was surveyed in mid-June 1980 . Four $150-\mathrm{m}(45-\mathrm{ft})$ transects were run from east to west crossing approximately $2 / 3$ the length of the site. The fenced area that contains the weather tower was the $1 / 3$ of the area not included. The transects were used to determine species composition, density, and dominance. Sixty $1-\mathrm{m}^{2}\left(3.2^{2}-\mathrm{ft}\right)$ plots were used to determine frequency and per cent cover. This site was not mapped because of the homogeneity of the vegetation and large acreage.

-Frank R. Craven, Member of H-8 vivision, has resided in Los Alamos since 1948, personal communication, Dec. 1980. 


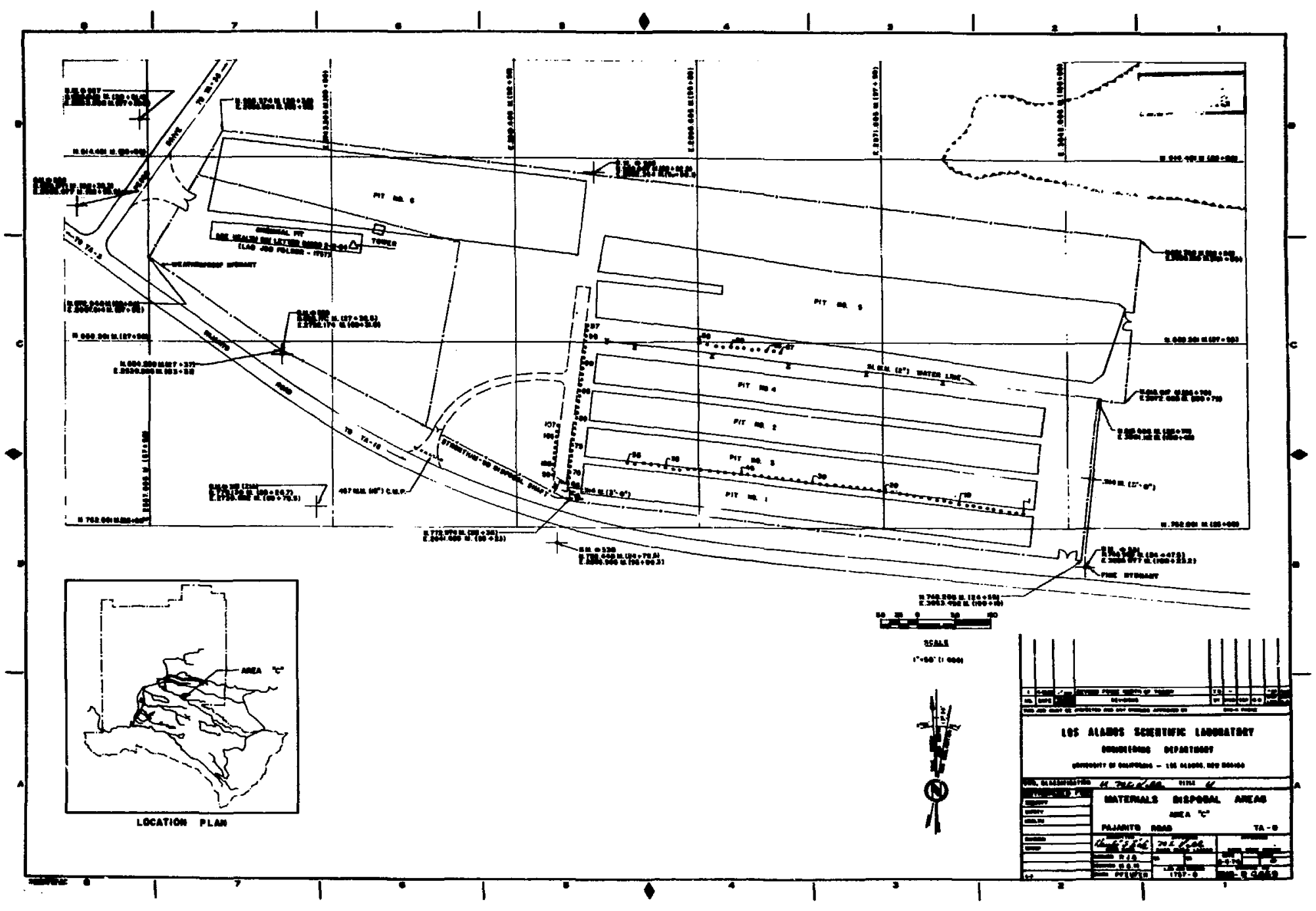

Fig. 6. Waste disposal area C, Pajarito Road, TA-0. Survey area designated. 


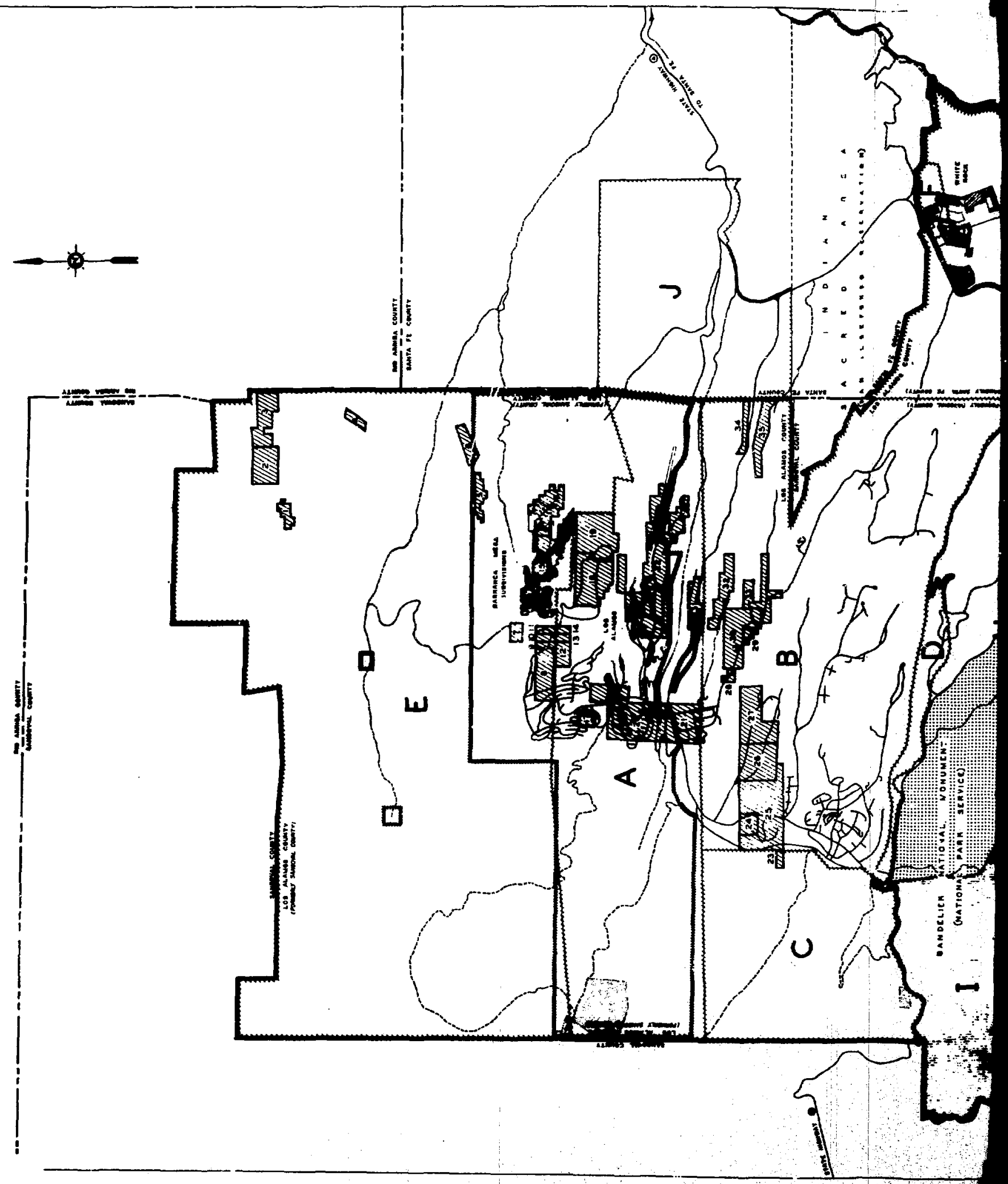




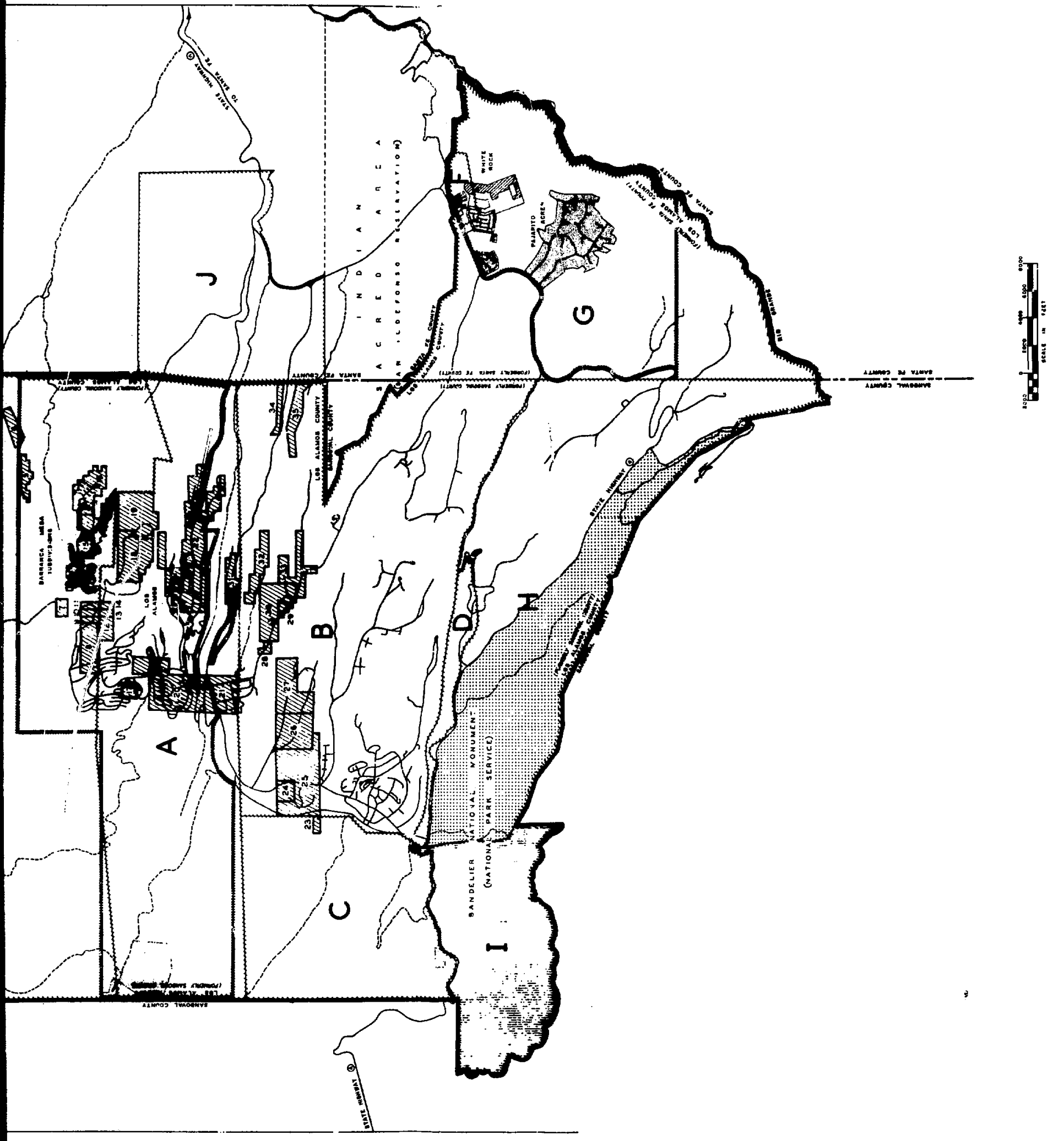




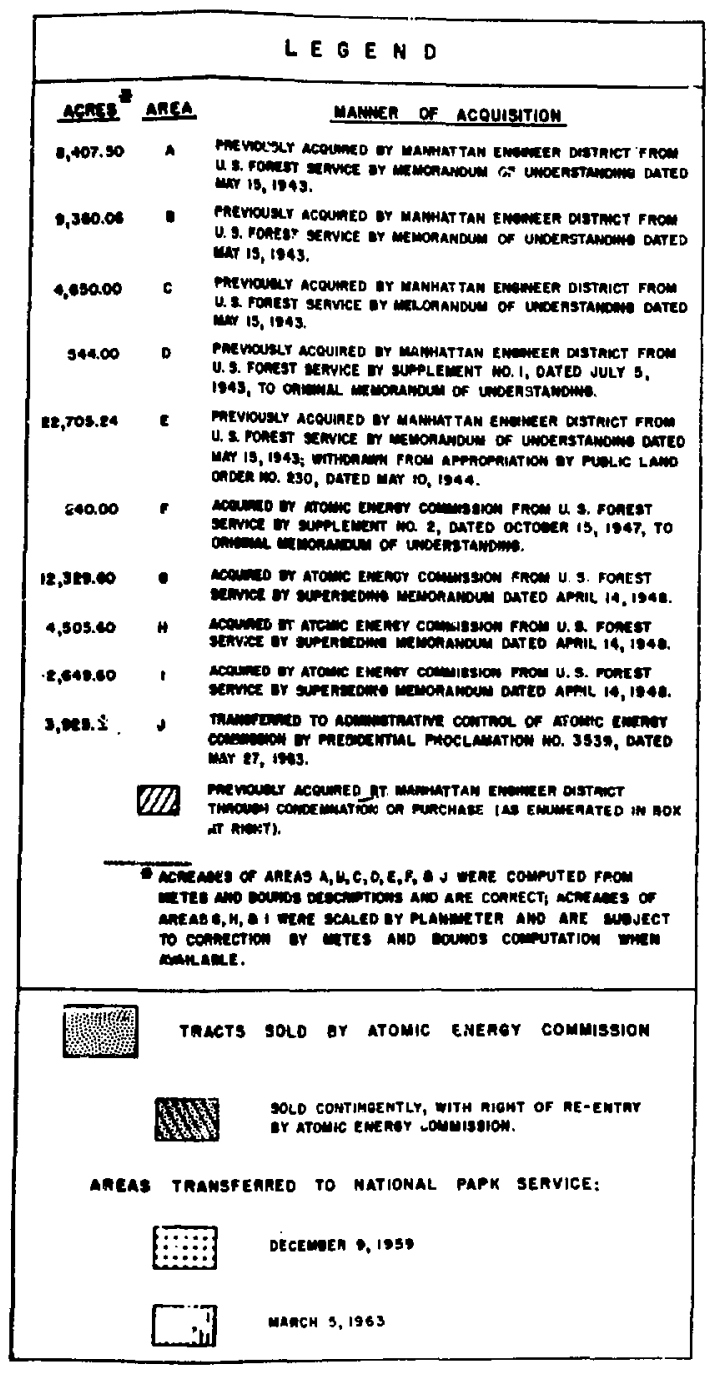

Fig. 7. Agricultural areas in Los Alamos County obtained by purchase or condemnation by the Alomic Energy Commission.

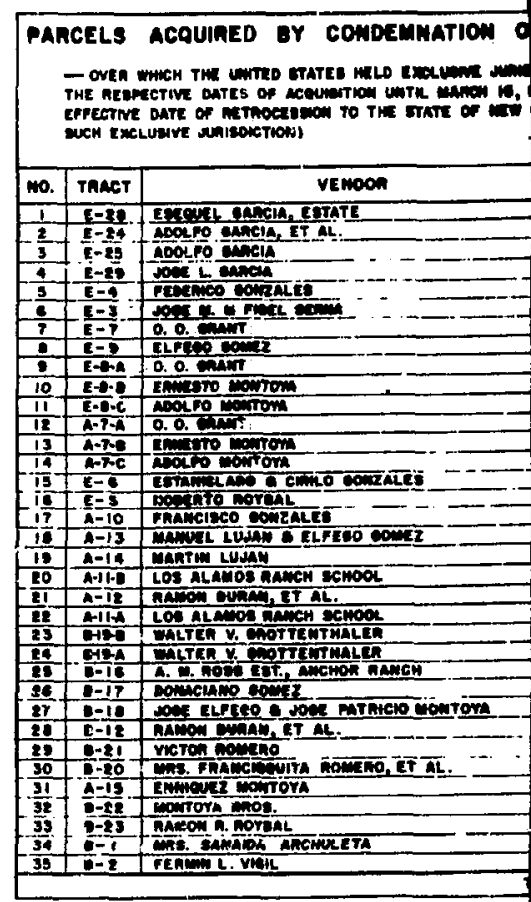

THIS MAP CONTAIms IMFOAmation on THE OY THE ATOMIC Emcher commisaion ic PREDECESSON AAEMCY) OF TAMCTS Of SITUATED WITHIM OA ADJACENT TO LS of CEnTAIH Thacts. 


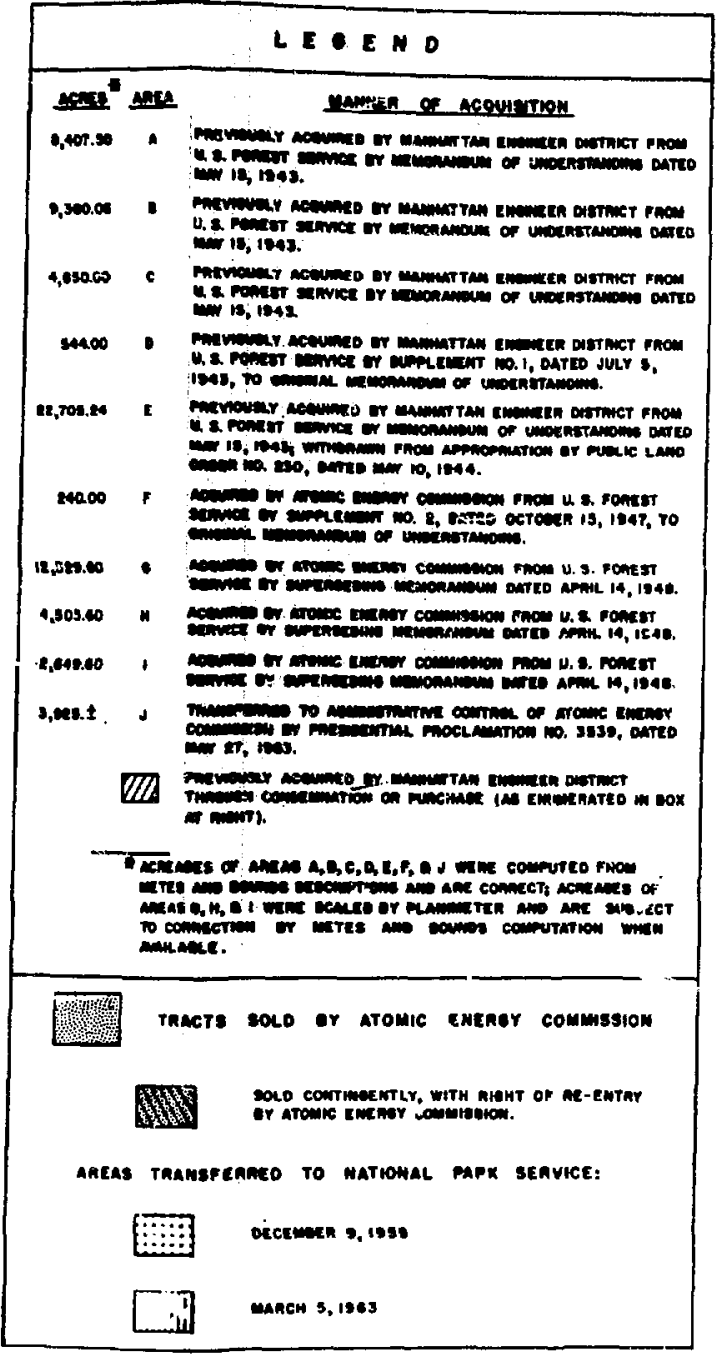

\begin{tabular}{|c|c|c|c|}
\hline \multicolumn{4}{|c|}{ 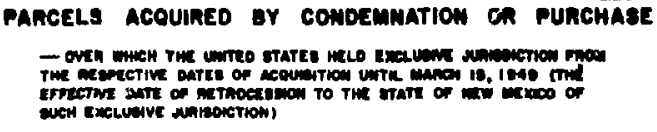 } \\
\hline n. & TAMGT & venoon & AGnLane \\
\hline$\frac{1}{3}$ & 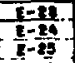 & 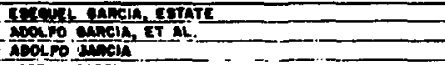 & $\frac{67.2}{1000}$ \\
\hline 4 & $2-2$ & $\operatorname{con} L$ & IIS \\
\hline$\underline{s}$ & $t=6$ & 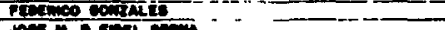 & P5s \\
\hline$\frac{8}{7}$ & $E-3$ & 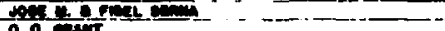 & 0.10 \\
\hline$\frac{7}{9}$ & $\frac{1}{E-1}$ & $\frac{0.0 .}{12}$ & $\frac{0.00}{1000}$ \\
\hline 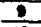 & $E-4$ & $0.0 . \min$ & $\frac{10.00}{10.00}$ \\
\hline 10 & $E$ & 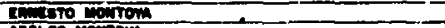 & 10.00 \\
\hline 11 & E-6.e & Ampo ventom & \\
\hline 12 & $A=7-A$ & $0.0 . \operatorname{con} 1$ & 0.00 \\
\hline 13 & $A-T-P$ & 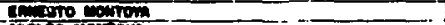 & 1900 \\
\hline 19 & $a-7$ & Exato now & The \\
\hline 15 & $E-B$ & 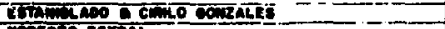 & I5:.6 \\
\hline is & 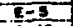 & W Thro mor LL & ILBou \\
\hline 17 & $A-10$ & 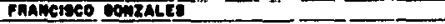 & 2.50 \\
\hline in & $A-13$ & 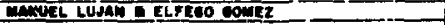 & 180.00 \\
\hline 18 & $A-19$ & ANTIN LUJAN & 10000 \\
\hline 20 & A-1BD & RAMCH SYYOOL & 200 \\
\hline हI & A一E & 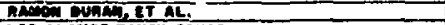 & 10,00 \\
\hline 21 & Anthe & TOSALRWOS RCWCH SCHOOL & 90.00 \\
\hline 23 & GF & WALTES Y. COOTTITTMALEA & 20.10 \\
\hline 80 & Fin & 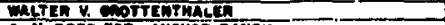 & $\$ 0.00$ \\
\hline 8 & -10 & 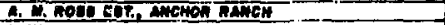 & 32.18 \\
\hline tel & 0.17 & Comalabo ton & Ine \\
\hline 27 & -10 & 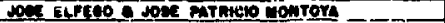 & \\
\hline 8 & $0-16$ & RACON COMAT, ET AL. & 1000 \\
\hline 28 & $2-21$ & Victon wowho & \\
\hline 30 & $0=0$ & 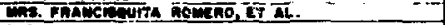 & 10000 \\
\hline 31 & $A=1$ & 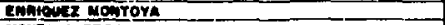 & n.o \\
\hline 39 & -2 & Comon chot. & \\
\hline 3 & $0-13$ & RANOM Roreal & 10750 \\
\hline 34 & -1 & Whs SinÁOA AnCHUCTA & 34.07 \\
\hline$\sqrt{5}$ & $0-2$ & FENTWL L VHIL & 0.31 \\
\hline & & TOTAL & $3,599,70$ \\
\hline
\end{tabular}

THIS WAP CONTAIN IMFOAMATION ON THE ACOUIEITION OY THE ATOHIC EMEROY COMHISsion (OA THE

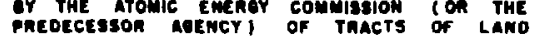
PITUATE WITHIN OR AOJACENT TO LOS ALAMOS COUNTY, AND ON THE SUDSEOUENT DISPOSITION OF CEATAIN TAACTS.

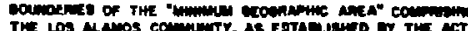

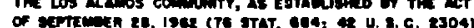

Fig. 7. Agricultural ancas in Los Alamos County obtained by purchase or condemnation by the acomuc Energy Commission.

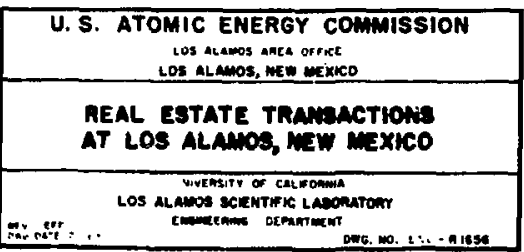




\section{TABLE II}

\section{IMPORTANCE VALUE OF SELECTED SPECIES ON WASTE DISPOSAL SITE C}

\begin{tabular}{|c|c|c|}
\hline Species & Common Name & $\begin{array}{l}\text { Importance } \\
\text { Value }\end{array}$ \\
\hline Artemisia dracwnculus & false terragon & 32 \\
\hline Sporobolus cryptandrus & sand dropseed & 14 \\
\hline Verbascum thapsus & mullein & 7 \\
\hline Bromus tectorum & downy chess & 6 \\
\hline Melilotus spp. & sweet clover & 5 \\
\hline Sphaeralcea spp. & globe mallow & 4 \\
\hline Sitanion hystrix & squirrel tail & 3 \\
\hline Artemisia carruthii & wormweod & 2 \\
\hline Grindelia aphanactis & gumweed & 2 \\
\hline Cryptantha jamesii & hidden flower & 1 \\
\hline Robinia neomexicana & New Mexico locust & 1 \\
\hline Kochia scoparia & summer cypress & 1 \\
\hline Aristidia divaricata & poverty 3-awn & 0.8 \\
\hline Muhlenbergia montana & mountain muhly & 0.7 \\
\hline Bouteloua gracilis & blue grama & 0.7 \\
\hline Poa spp. & blue grass & 0.4 \\
\hline Geranium caespitosum & James' geranium & 0.4 \\
\hline Oenothera spp. & evening primrose & 0.5 \\
\hline Rosa woodsii & wild rose & 0.3 \\
\hline Chenopodium spp. & lamb's quarters & 0.3 \\
\hline
\end{tabular}

F. Results

A total of 29 species (Appendix A) were recorded along the transects and within the plots. Of these 29 species, $21 \%$ were annuals, $52 \%$ perennials, $17 \%$ biennials, $7 \%$ shrubs, and $3 \%$ trees. Introduced species represented $21 \%$ of the total species found. Grasses made up $28 \%$, whreas forbs made up $62 \%$. The largest percentages of species helonged to either the sunflower family (Compositae 21\%) or grass family (Graminae 28\%). A total of 13 families are representod.

The site was dominated by false terragon, with sand dropaeed (Sporobolus cryptandrus) of lesser importance. Other species with significant importance values included (in order of decreasing importance) mullein, downy chess (Bromus tectorum), and sweet clover. Table II gives the calculated importance values for less significant species found on the site.

Total foliage cover for the site was $12.8 \%$ folinge cover $/ \mathrm{m}^{2}$. False terragon represented $6.8 \%$ of the total foliage cover. 


\section{G. Discussion}

Area $\mathbf{C}$ is in an early seral stage of vegetation, as reflected in the number of annuals on the site and the relatively large percentage of introduced species. The area was probably cleared for farming in the early 1900 s, worked until 1942, and lay fallow until 1948. Disturbance of the site began again when it was opened as a disposal site in that year. The entire site was closed in 1974. However, pits that made up the surveyed area were closed earlier, in 1963. The surveyed section has lain fallow for $17 \mathrm{yr}$.

Eight of the nine plants with the greatest importance value are known invaders of old agricultural areas. Species of two genera are often used to revegetate disturbed areas (sweet clover and sand dropseed). There is no indication, however, that any attempt to revegetate the area was made. The main source for revegetation of the site was probably the land adjacent to the road, which is in the seral stage of historic fields succession. However, seeds of species such as sweet clover have been found to remain viable up to $50 \mathrm{yr}$, and the soils of the waste site proper also could have been the seed source. ${ }^{19}$

The only species with a significant importance value found in the surrounding ponderosa pine forest was mountain muhly (Muhlenbergia montana). Tree and shrub species in the interior of the site are merely seedlings that have invaded the area from the adjacent forest.

During the course of the survey, a plague of grasshoppers infected many of the study areas, including area $\mathrm{C}$, and the clover was eaten to within a few inches of the ground.

\section{DESCRIPTION OF WASTE DISPOSAL AREA E}

\section{A. Location}

Area $E$ is located at the southernmost extension of TA-33. Township and range are SE $1 / 2$ sec. 24, T. 18N, R6E (see Ref. 5 for Laboratory coordinates). The area of the site within the barbed-wire fence is approximately 0.028 ha $(0.69$ acres). Our measured dimensions are: NW corner to $\mathrm{SW}$ corner, $43.95 \mathrm{~m}$ $(144 \mathrm{ft})$; $\mathrm{SW}$ corner to $\mathrm{SE}$ corner, $61.40 \mathrm{~m}(201 \mathrm{ft}) ; \mathrm{SE}$ corner to NE corner, $42.90 \mathrm{~m}(140 \mathrm{ft})$; and NE corner to NW corner, $61.10 \mathrm{~m}(200 \mathrm{ft})$.

The site lies on a dry, windy promontory of an unnamed mesa that appears to be part of the Burnt Mesa-Frijoles Mesa complex. Elevation is about $1963 \mathrm{~m}(6440 \mathrm{ft})$. The mesa point is formed by tributaries that drain into Chaquehui Canyon to the south. The mesa slopes gently towards that canyon; the edge is about $6 \mathrm{~m}$ (18 ft) from the fence at the south end of the site (Fig. 8).

\section{B. Physical Description}

Area $\mathrm{E}$ is entirely enclosed by a sturdy three-strand barbed wire fence hung on steel posts. There is no gate. Soil cover is thin in the area surrounding the site, and numerous tuff outcrops are visible. The soil on the site proper is thin and is mostly crushed tuff. At present, area E appears to be nearly level. There are two large slabs of concrete on the site, one which slumped to reveal a chamber that may trap water. The slabs divert runoff to their edges. The chamisa around them grows up to $1.8 \mathrm{~m}(6 \mathrm{ft})$ wide and $1.37 \mathrm{~m}$ (4$1 / 2 \mathrm{ft}$ ) high. On the east side outside the fence, a pile of rubble (oriented roughly north-to-south) runs the length of the site, and a dip between the rubble pile and the fence has been established. $A$ low ridge of rubble runs along the west side of the site inside the fenc. The natural north-to-south drainage has not been changed. The north end of the site is disturbed by access roads. There is no impediment on the south side to stop water from washing across the site and over the edge of the canyon. Just outside the southern and western sides of the site are the least disturbed surrounding areas. There is very little evidence of rodent activity. 


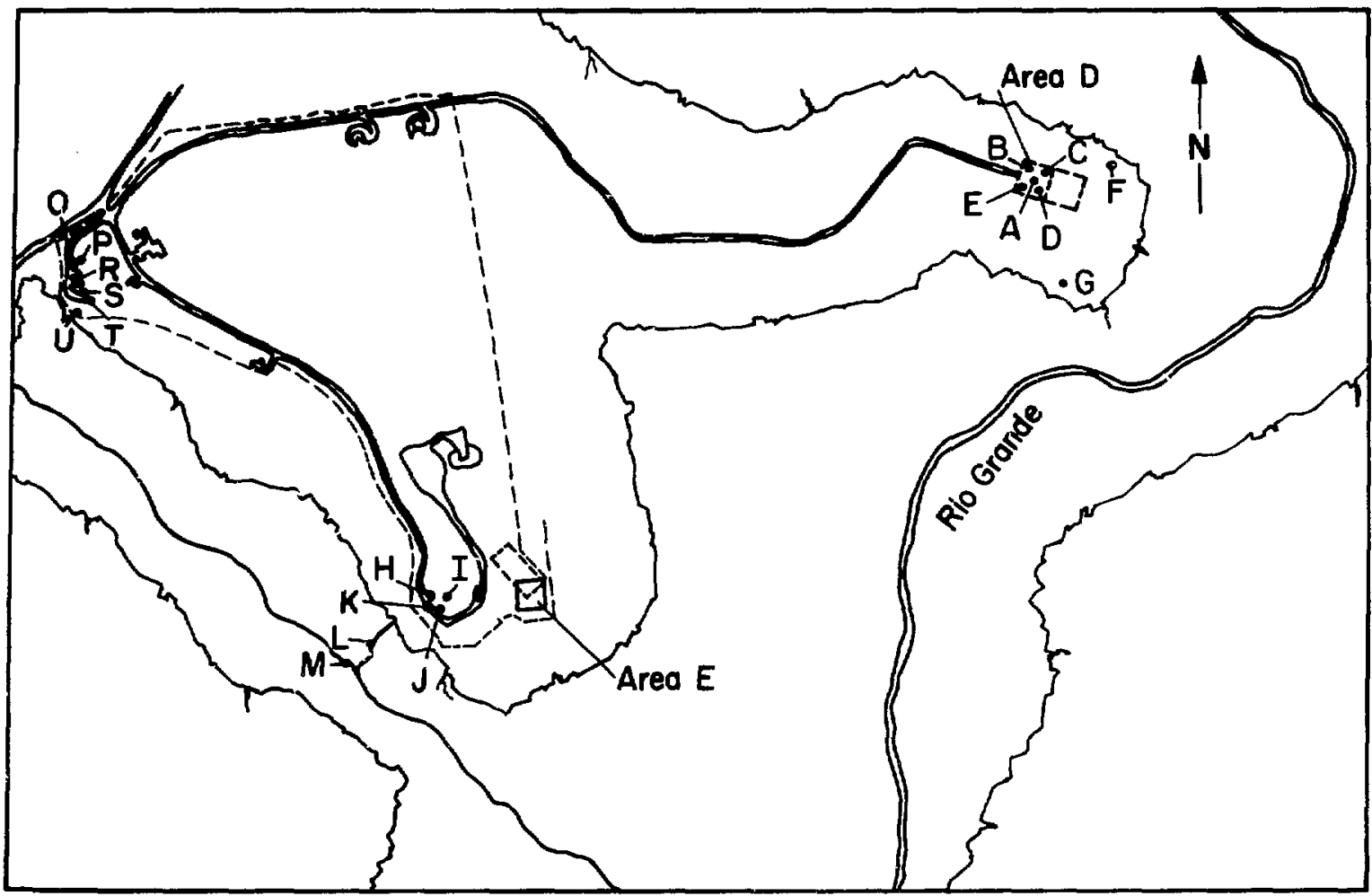

Fig. 8. Waste disposal site $E$.

\section{History}

According to the information synthesized by Rogers, ${ }^{5}$ area E disposal site was probably opened in 1949 and closed by 1963. There is little information as to when area $\mathrm{E}$ last saw extensive disturbance. According to Rogers, the last notes on the site were made in 1963, when a USGS report stated, "The fill probably should be compacted and mounded to minimize erosion and ponding of water around the pits."

We can only hypothesize that the site was periodically disturbed for $14 \mathrm{yr}$ (1949 to 1963) and then left undisturbed for $17 \mathrm{yr}$ (1963 to present). During our survey of the site and adjacent areas, we found no evidence of prehistoric use, although an Indian shrine lies to the southeast, and there are prehistoric ruins close to TA-33, according to Laboratory archeologist * Charlie Steen. Examination of old photographs of the Pajarito Plateau turned up no evidence of historic fields or homesteads near area $\mathrm{E}$, nor did we see any physical evidence of nearby historic disturbance (such as fence, rorral, or cabin ruins) during the ground survey. Apparently, the area $E$ near-surface landfill disposal facility was placed originally on undisturbed terrain.

*Personal communication, Dec. 1980, Charlie R. Steen, current Los Alamos National Laboratory Archeologist. 


\section{Vegetation Overview}

Area $E$ is situated within the pirion-juniper community near the ecotone into juniper grassland. The present vegetation reflects the natural vegetation of the area outside the confines of TA-33. The natural vegetation here consists of large piñon and juniper trees, native grasses, pad cactus, and some forbs. In our first inspection of the site (May 29, 1980), we listed all plants we could identify on the site. Then we listed all observed plants on the nearby mildly disturbed areas south and west of the site. The two lists of about 20 species each were nearly the same. Some differences are explained by the fact that the site is in a successional state and several native species usually associated with disturbed soil (either natural or anthropogenic disturbance) and perhaps extra soil moisture are present on the site. These disturbed area species are the shrubs: chamisa (Chrysothamnus nauseosus), Apache plume (Fallugia paradoxa), saltbush (Altriplex canescens), and the grass, poverty 3-awn (Aristida divaricata). Other differences are simply explained by the site's being protected from grazing. For example, rice grass (Oryzopsis hymenoides) was seen only on the waste site within the fence. Rice grass is a high protein, native grass much preferred by grazing animals, which there is evidence of between the southern side of the site and Chaquehui Canyon.

Trees on the site are relatively small, as expected. The piñon (Pinus edulis) are about $1 / 2 \mathrm{~m}(1.5 \mathrm{ft}$ ) tall as compared with 4.6-m (15-ft) high piñon on the canyon rim outside of the fence. The juniper (Juniperus monosperma) are also small, 1 to $1-1 / 3 \mathrm{~m}$ ( 3 to $4 \mathrm{ft}$ ) in comparison with their conspecifics outside of the site. Outside of the disposal site, vegetation consists mainly of native grasses, snakeweed, prickly pear cactus (Opuntia spp.), and a few forbs.

\section{E. Procedure}

Area $\mathrm{E}$ was dissected by three transects placed at intervals to avoid the cement slab. Transect one was

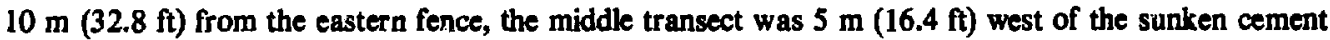
slab, and the last transect ran $10 \mathrm{~m}(32.8 \mathrm{ft})$ in from the western fence. Each transect ran from north to south and was about $43 \mathrm{~m}$ (13 ft) long. Species composition, density, and dominance were read from the transects. Fifteen $1-\mathrm{m}^{2}\left(3.2^{2}\right.$-ft) plots were used to determine frequency and per cent foliage cover. The site was then mapped on approximately $1.5-$ to $2-\mathrm{m}$ (4.9-ft to 6.6-ft) quadrats to show vegetation distribution (Fig. 9).

\section{F. Results}

A total of 24 species were recorded along the transect and within the plots. Of these 24 species, $4 \%$ were annuals, $63 \%$ perennials, $8 \%$ biennials, $17 \%$ shrubs, and $8 \%$ trees. Introduced species represented $8 \%$ of the total species found. Grasses made up $29 \%$, whereas forbs made up $46 \%$. There were $29 \%$ of the species in the grass family (Graminae) and 50\% in the sunflower family (Compositac). Seven families were represented.

The site was dominated by poverty 3-awn with golden aster (Chrysopsis villosa) of lesser importance. Sweet clover (Melilotus Spp.), chamisa, snakeweed, and piñon were of significance. Calculated importance values for these and other species on the site are in Table III. It might be noted that the periphery of the large concrete pad was essentially lined by chamisa. The transects did not intersect this area, or chamisa would have probably had a greater importance value.

Total foliage cover for the site was $15.2 \% / \mathrm{m}^{2}$. Poverty 3-2wn made up $5.6 \%$ and goldenweed $3.4 \%$ of the foliage cover for plot samples. 


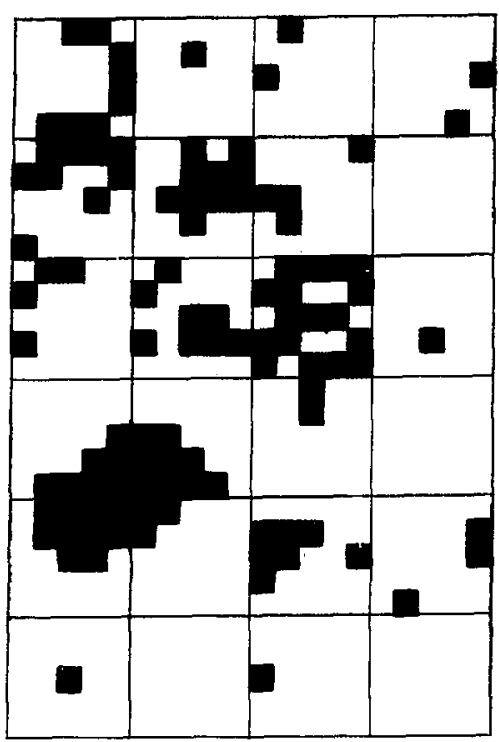

Bare Ground

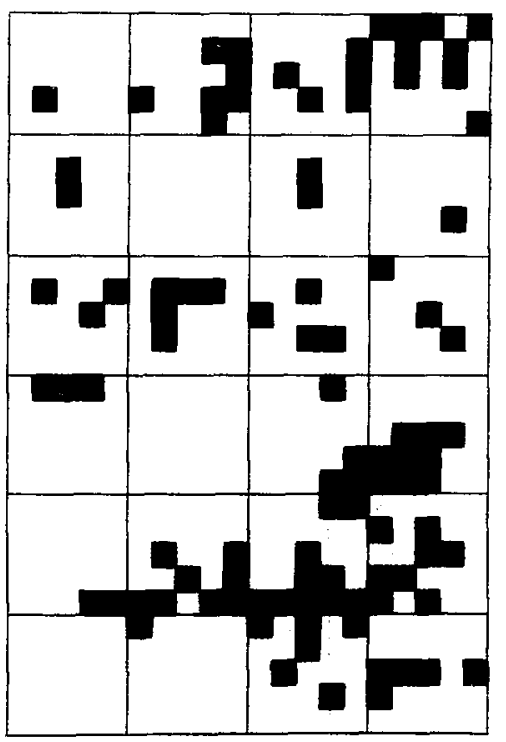

Native Gizes

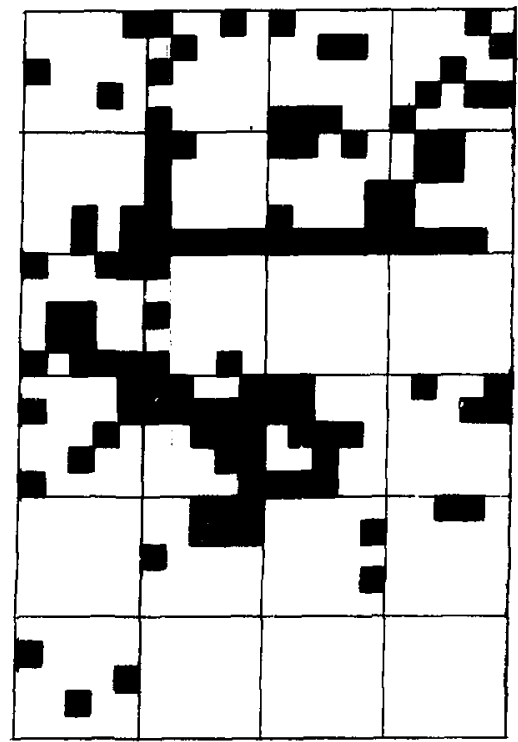

Chrysothamnus

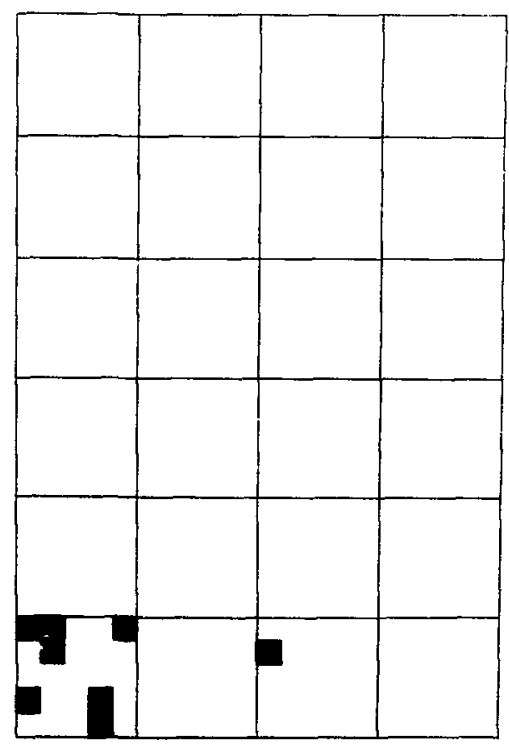

Introduced Grass

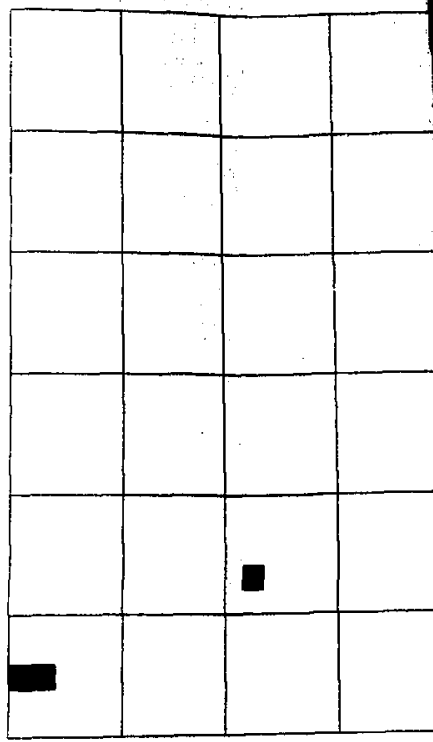

Metipotus

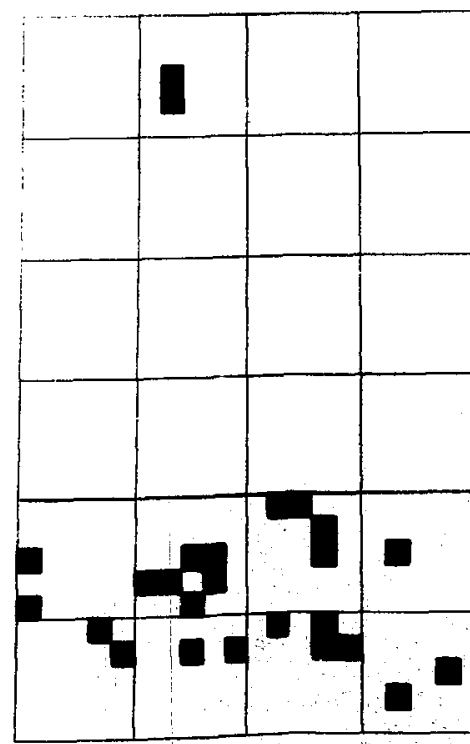

Mellotus-Fotb-Grass

Fig. 9. Compusertzed vegetation mop of waste dipposal sive $E$. 


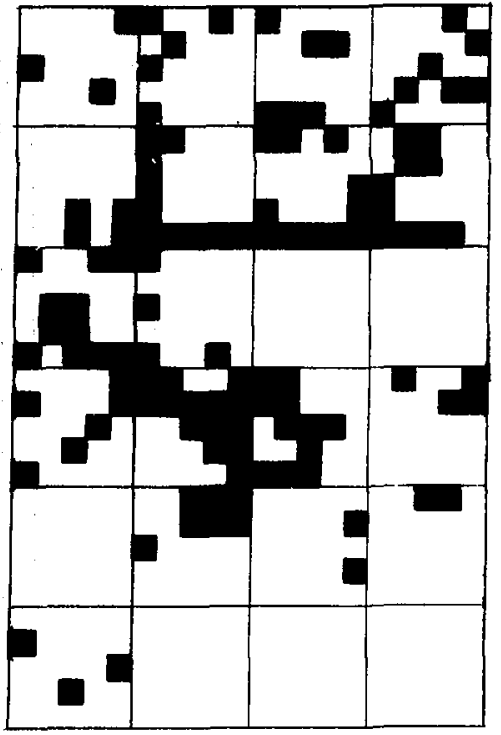

Chrysothammus

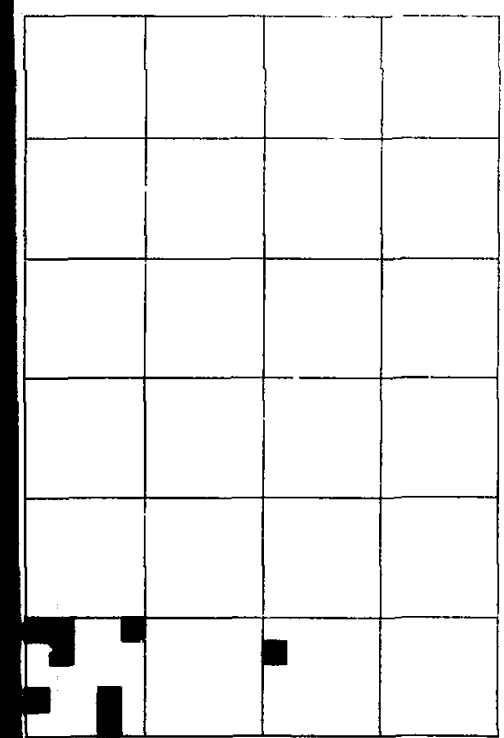

Introduced Grass

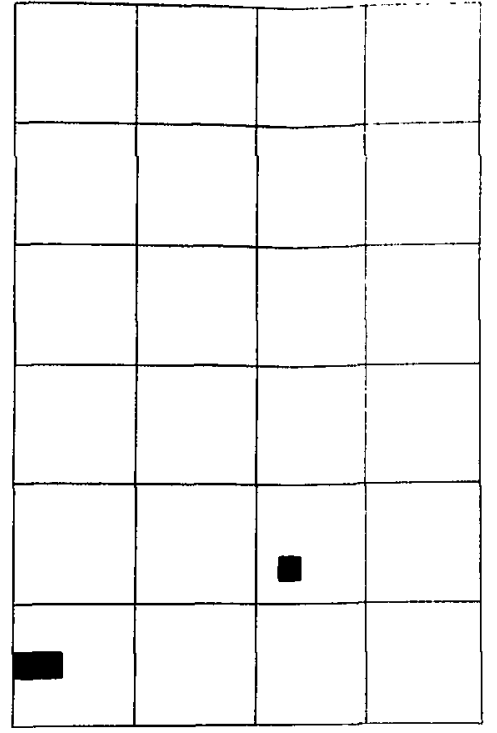

Mellotus

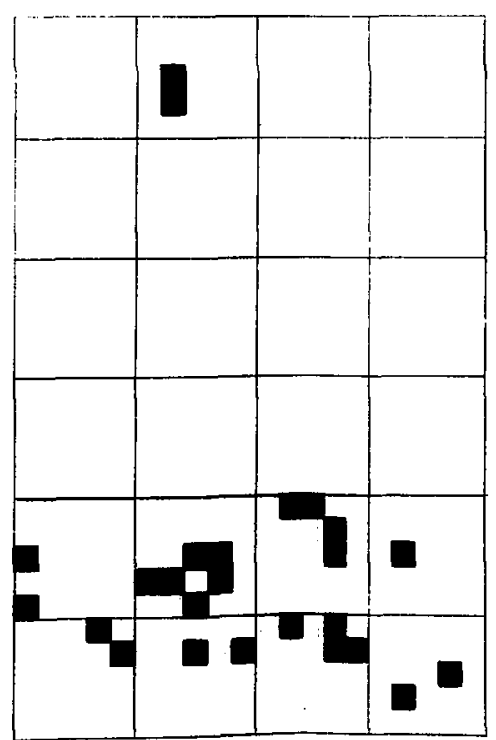

Melllotus-Forbs-Grass

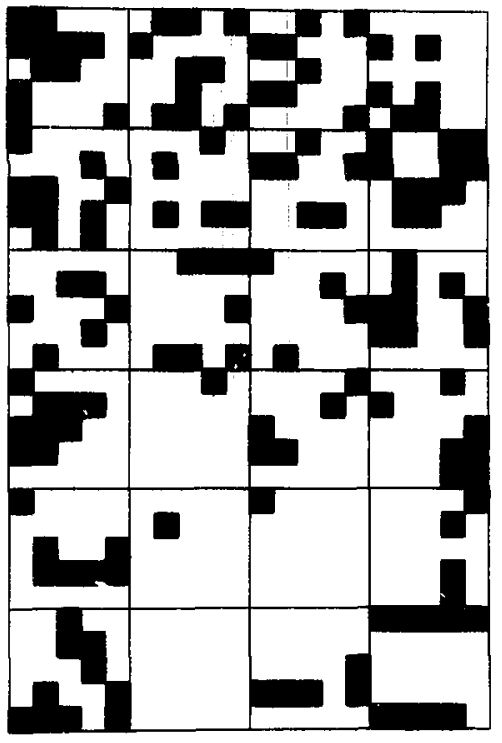

Forbs

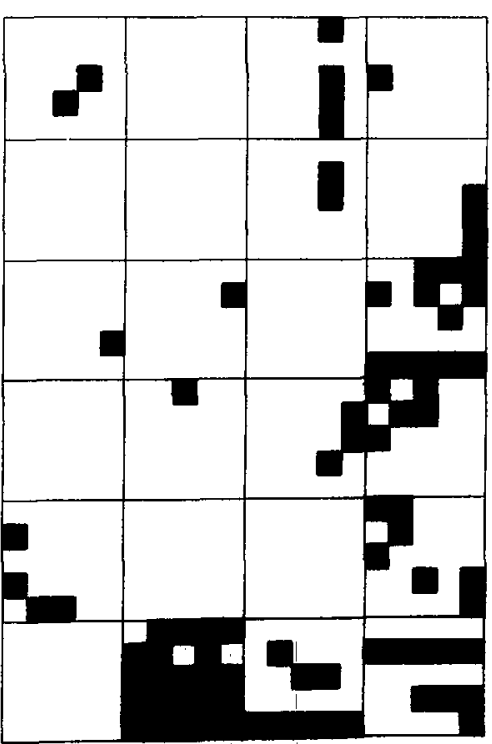

Grass-Forbs

Fig. 9. Computerized vegetation map of waste disposal site $E$. 


\section{IMPORTANCE VALUES FOR SELECTED SPECIES ON WASTE DISPOSAL SITE E}

\begin{tabular}{|c|c|c|}
\hline Species & Common Name & $\begin{array}{c}\text { Importance } \\
\text { Value }\end{array}$ \\
\hline Aristida divaricata & poverty 3-awn & 25 \\
\hline Chrysopsis villosa & golden aster & 19 \\
\hline Melllotus spp. & sweet clover & 14 \\
\hline Chrysothamnus nauseosus & chamisa & 7 \\
\hline Gutierrezia micrucephala & snakeweed & 6 \\
\hline Haplopappus spinulasus & spiny golden aster & 5 \\
\hline Oryzopsis hymenoides & rice grass & 4 \\
\hline Artemisia dracunculus & false terragon & 3 \\
\hline Stipa comata & needle grass & 3 \\
\hline Sitanion hystrix & squirrel tail & 2 \\
\hline Sporobolus cryptandrus & sand dropseed & 2 \\
\hline Tetradymia canescans & horsebush & 2 \\
\hline Atriplex canecans & four-wing saltbush & 1 \\
\hline Juniperus monosperma & one-seed juniper & 1 \\
\hline Hymenopappus filfolius & white ragweed & 1 \\
\hline Bouteloua gractlis & blue grama & 0.9 \\
\hline Kuhnia chlorolepsis & false boneset & 0.8 \\
\hline Bahia dissecta & bahia & 0.8 \\
\hline
\end{tabular}

A line transect run outside the south fence showed that snakeweed was of greatest importance. Other species of decreasing importance included galleta (Hilaria jamesii), prickly pear cactus (Opuntia polycantha), and blue grama.

\section{G. Diecussion}

The present vegetation of area $\mathrm{E}$ is only reminescent of the surrounding area. The site is still in secondary succession with a large percentage of species being perennials, shrubs, and trees, whereas a low percentage are annuals.

The site has a number of native species characteristically found in disturbed habitats. These are poverty 3-awn, chamisa, four-winged saltbush, and false terragon. Only in the southwest corner of the plot was there much native grass. The extent of the native vegetation is large enough and cloae enough to provide almost all the eed source for revegetation. Only one nonnative plant was found in area $\mathbf{E}$, and that was white sweet clover (Melllotus albus), an escaped cultigen. It was probably introduced to the site through cattle or deer dung. Some evidence of selective browing within the fenced site was noted. Because the fence is too tight for intrusion by cattle, we suspect the browers were deec. Other native ${ }^{\text {in }}$ creaser" species such as snakeweed and poverty 3-awn are to be expected in a succestional state characterized by open habitats. 
The interior of the fenced area has been protected from overgrazing. The area surrounding the site has evidence of grazing and bedding by cattle. The dominance of snakeweed and prickly pear cactus reflect this form of disturbance. In addition, within the plot, a palatable grass (ricegrass) was found but was not represented on the grazed exterior. The topography of this site has been so changed that it is unlikely that it will ever reach the original climax, but will probably continue as an association similar to that found in arroyos or on roadsides of the piñon-juniper grassland.

\section{DESCRIPTION OF WASTE DISPOSAL AREA F}

\section{A. Location}

Area $F$ is located on Two Mile Mesa north of Two Mile Mesa road about halfway between the guard gate and TM site. A large, stabilized pile of fill at the eastern end of the site acts as a landmark. The township and range description read: near the middle of sec. 20, T., 19N, R6E (Fig. 10).

\section{B. Physical Description}

Two waste burial sites are included in area $\mathrm{F}$. We refer to the smaller as $\mathrm{Fa}$ and the larger as $\mathrm{Fb}$. The total area of these sites is about $7.2 \times 10^{2} \mathrm{~m}^{2}(0.072 \mathrm{ha})$. The dimensions we measured for area Fa are:

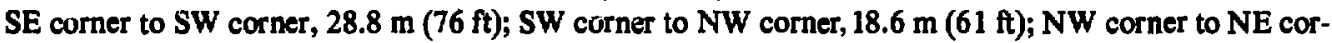
ner, $21.1 \mathrm{~m}(69.2 \mathrm{ft})$; and NE corner to SE corner, $16.2 \mathrm{~m}(53.1 \mathrm{ft})$. Only the bench markers indicate the corners of each of the waste burial sites. They are not otherwise marked or fenced; although there are some strands of barbed wire laying on the ground about $3.1 \mathrm{~m}(10 \mathrm{ft})$ in from the bench markers on Fa. $\mathrm{Fa}$ is the closest to the road, about $3 \mathrm{~m}$ (10 $\mathrm{ft})$, whereas $\mathrm{Fb}$ is northeast, closer to the forested area, and about $15.2 \mathrm{~m}(50 \mathrm{ft})$ from the road.

Two Mile Mesa is part of the plateau area adjoining the Jemez Mountain Range. It is bounded on the north and south by tributary canyons of Pajarito Canyon (the southern tributary is sometimes referred to as Two Mile Canyon). Base rock of the mesa is volcanic tuff. Area $\mathrm{F}$ lies about equal distance from both tributary canyons. Fa is nearly level, whereas $\mathrm{Fb}$ slopes slightly to the north.

\section{History}

To the south of the site are historic fallow fields associated with the Gomez-Anchor ranch (Fig. 7) complex, whereas to the north of the site is a ponderosa forest. A deep, back-cutting arroyo just outside the northwest side of area $\mathrm{Fb}$ and sheet washing were mentioned in a USGS report of 1963 . Both conditions are still present. Information from documents cited in Rogers' report indicates that area $F$ was opened and closed in $1946 .{ }^{5}$ The site has thus, according to the documents, been closed to disturbance for some $34 \mathrm{yr}$, and this figure was confirmed by Al Van Vessem.* This area has been ciosed longer than any of the other waste disposal sites studied at the Laboratory.

-Personal communication, Aug. 1980, Alan R. Van Vessem, Member of MAT-3 Division, Los Alamos National Laboratory. 


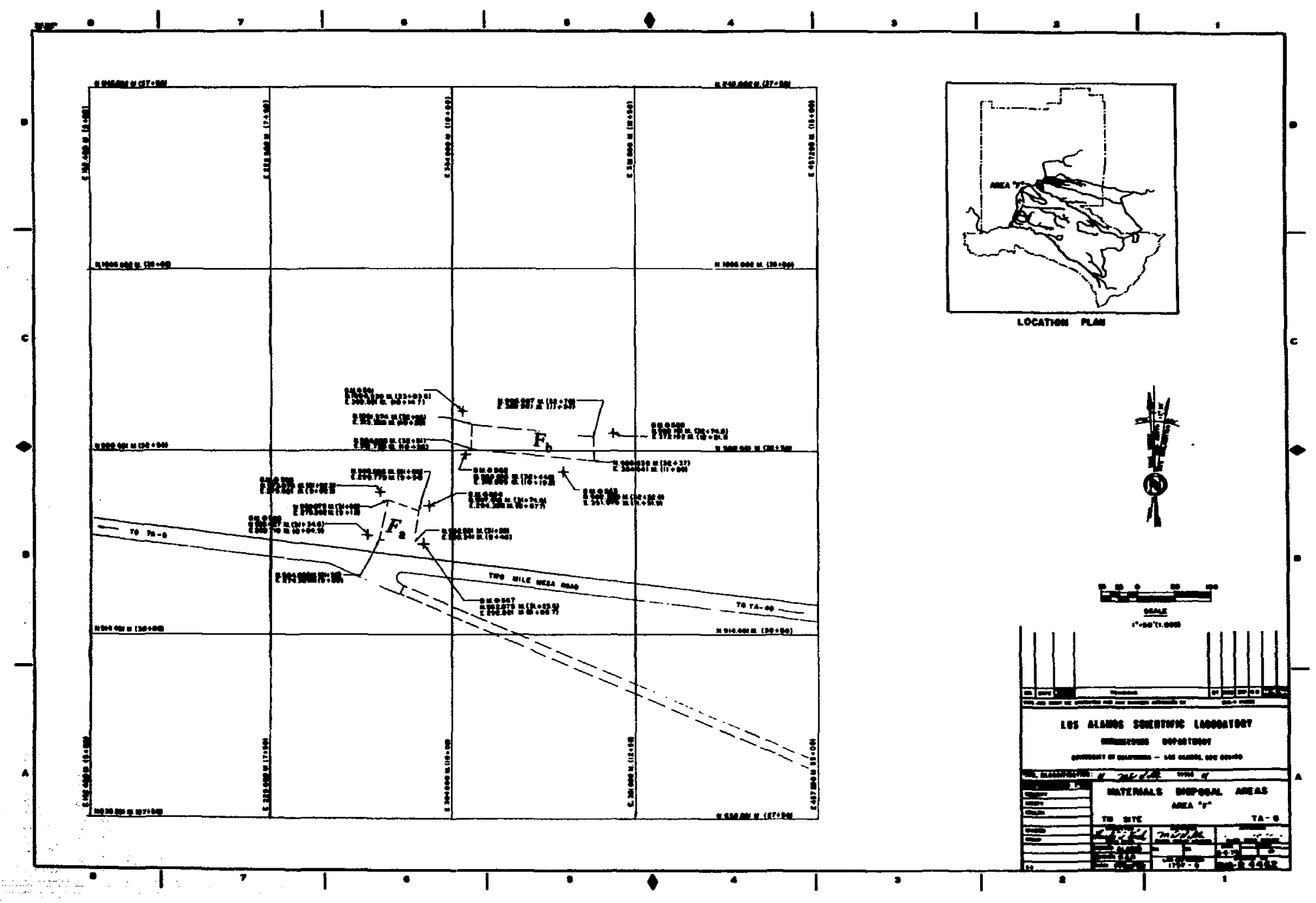

Fig. 10. Waste Disposal Area F, TM Site, TA-6. 


\section{Vegetation Overview}

Area $F$ is situated on abandoned historic fields within the ponderosa pine zone at an elevation of approximately $2271 \mathrm{~m}$ (7450 ft). Vegetation on the site reflects its previous land use history. Fa pit sits closest to the road and adjoins the historically cleared area, or may be part of that clearing. Its vegetation is much the same as the historic fields. A considerable amount of sheet washing exists to the north side. $\mathrm{Fb}$, on the other hand, is less than $25 \mathrm{~m}$ from the natural forest ecotone, and much of its vegetation is similar to open forest habitat. The adjacent ponderosa pine forest is rather even-aged with trees measuring approximately $15.2 \times 25.4 \mathrm{~cm}(6$ to $10 \mathrm{in}$.) dbh. There is some evidence of previous fire, but little evidence of recent reproduction of pines. The open field shows invasion of ponderosa pine from the forest edge and a seral stage in succession. Although both waste disposal pits of area $F$ are revegetated with primarily native species, the species composition between the two is somewhat different (Table IV).

\section{E. Procedure}

Area $F$ consists of two small pits. Each was surveyed and the vegetation analyzed separately. Although physically close, vegetation on each was quite different:.

Area $\mathrm{Fa}$ is the smaller of the two plots, measuring $23.8 \times 18.6 \times 21.1 \times 16.2 \mathrm{~m}(78.1 \times 61 \times 69.2 \times$ $53.1 \mathrm{ft}$ ). Three transects were run across the length of the plot, and twelve $1 \mathrm{~m}^{2}$ quadrats were used to sample vegetation for foliage cover and frequency.

The large plot $\mathrm{Fb}$ was narrow and elongated with a length of approximately $64 \mathrm{~m}(209.9 \mathrm{ft})$ to the north, $41 \mathrm{~m}(134.4 \mathrm{ft})$ to the south, $18.4 \mathrm{~m}(60.4 \mathrm{ft})$ to the west, and $26.4 \mathrm{~m}(86.6 \mathrm{ft})$ to the east. Since vegetation was not homogeneous, four transects of approximately $50 \mathrm{~m}(165 \mathrm{ft})$ in length were run along the length of these plots. Vegetation was aiso sampled in twenty-six $1-\mathrm{m}^{2}\left(3.2^{2} \mathrm{ft}\right)$ plots for foliage cover and frequency. Each site was mapped in approximately $1.5-$ to $2-\mathrm{m}$ (4.9- to 6.6-ft) quadrats to show vegetation differences (Figs. 11, 12).

\section{F. Results}

At FA site, 23 species (Appendix B) were recorded along the transects and within the plots. Of these species, $13 \%$ were annuals, $57 \%$ perennials, $26 \%$ biennials, and $4 \%$ were trees. No shrub species were recorded on this site. Introduced species represented $9 \%$ of the total species found. Grasses made up $22 \%$ and forbs $74 \%$. The largest number of species belonged to the sunflower family (Compositae, 43.5\%) and the grass family (Graminae, 21.7\%). A total of nine families were represented.

The site was dominated by wormwood (Artemisia carruthii) and fleabane daisy (Erigeron divergens). Species of sweet clover and false terragon were of lesser importance. Other species with signficant importance values are ennumerated in Table IV.

The total foliage cover for this site was $18.5 \mathrm{cover} / \mathrm{m}^{2}$. Wormwood represented $3.5 \%$ of the total foliage cover in the sampled plots.

At Fb site, 27 species were recorded along the transects within the plots. Of these 27 species, $3 \%$ were annuals, $74 \%$ perennials, $15 \%$ biennials, $4 \%$ shrubs, and $4 \%$ trees. Introduced species represented $4 \%$ of the total species found. Grasses made up $26 \%$ and forbs $58 \%$. The largest number of species belonged to the families: Compositae (37\%), Graminae (25.9\%), and Leguminosae (14.8\%).

The site was dominated by trailing fleabane (Erigeron flagellaris). Pinque (Hymenoxys richardsonil) and gayfeather (Liatris punctata) were of lesser importance. Calculated values for species in this site are found in Table IV.

Total foliage cover for the site was $10.9 \%$ foliage cover $/ \mathrm{m}^{2}$. Trailing fleabane daisy represented $1.7 \%$ foliage cover $/ \mathrm{m}^{2}$ and wormwood $2.2 \%$ foliage cover $/ \mathrm{m}^{2}$, in the sampled plots. 
TABLE IV

\section{IMPORTANCE VALUES FOR SELECTED SPECIES \\ ON WASTE DISPOSAL SITES Fa AND Fb}

\section{Species}

Fa

Artemisia carruthii

Erigeron divergens

Melilotus spp.

Erigeron flagellaris

Chrysopsis villosa

Artemisia dracunculus

Plantago purshii

Bromus tectorum

Hymenoxys richardsonii

Aristida divaricata

Pinus ponderosa

Artemsia ludoviciana

Penstemon spp.

Pinus edulis

Juniperus monosperma

Conyza canadensis

Oenothera spp.

Muhlenbergia montana

Linum neomexicanum

Tragopogon dublus

Bahia dissecta

Grindelia aphanactis

Fb

Erigeron flagellaris

Chrysopsis villosa

Hymenoxys richardsonit

Artemisia carruthil

Llatris punctata

Rosa woodsii

Oenothera spp.

Melliotus spp.

Artemista dracunculus

Pinus ponderosa

Sitanion hystrix

Linum neomexicanum

Muhlenbergia montana

Plantago purshit

Importance

Common Name

Value

$\begin{array}{ll}\text { wormwood } & 16 \\ \text { fleabane daisy } & 10 \\ \text { sweet clover } & 10 \\ \text { fleabane daisy } & 6 \\ \text { leafy golden aster } & 6 \\ \text { false terragon } & 6 \\ \text { woody Indian wheat } & 6 \\ \text { downy chess } & 6 \\ \text { pinque } & 5 \\ \text { poverty 3-awn } & 5 \\ \text { ponderosa pine } & 3 \\ \text { wormwood } & 3 \\ \text { beards tongue } & 2 \\ \text { piñon pine } & 2 \\ \text { one-seed juniper } & 2 \\ \text { horse weed } & 1 \\ \text { evening primrose } & 1 \\ \text { mountain muhly } & 1 \\ \text { New Mexican flax } & 1 \\ \text { goatsbeard } & 0.9 \\ \text { bahia } & 0.7 \\ \text { gumweed } & 0.7\end{array}$

trailing fleabane $\quad 16$

leafy golden aster $\quad 12$

pinque 11

wormwood 10

gayfeather 7

wild rose 6

evening primrose 5

sweet clover 4

false terragon 3

ponderosa pine 3

squirrel tail 3

New Mexico flax 2

mountain muhly 2

woolly Indian wheat 2 
TABLE IV (Cont)

\begin{tabular}{|c|c|c|}
\hline Species & Common Name & $\begin{array}{c}\text { Importance } \\
\text { Value }\end{array}$ \\
\hline Petalostemum candidum & prairie clover & 2 \\
\hline Artemisia ludoviciana & wormwood & 2 \\
\hline Bouteloua gracilis & blue grama & 1 \\
\hline Pensteman spp. & beard's tongue & 1 \\
\hline Vicia americana & American vetch & 1 \\
\hline Sporobolus cryptandrus & sand dropseed & 1 \\
\hline Andropogon scoparius & little bluestem & 17 \\
\hline Bahia dissecta & bahia & 0.8 \\
\hline Andropogon scoparius & little bluestem & 0.7 \\
\hline Hymenopappus fllfolius & white ragweed & 0.6 \\
\hline Solidago spp. & goldenrod & 0.5 \\
\hline Juniperus monosperma & one-seed juniper & 0.5 \\
\hline Taraxicum officinale & dandelion & 0.4 \\
\hline Lithospermum spp. & puccoon & 0.4 \\
\hline
\end{tabular}

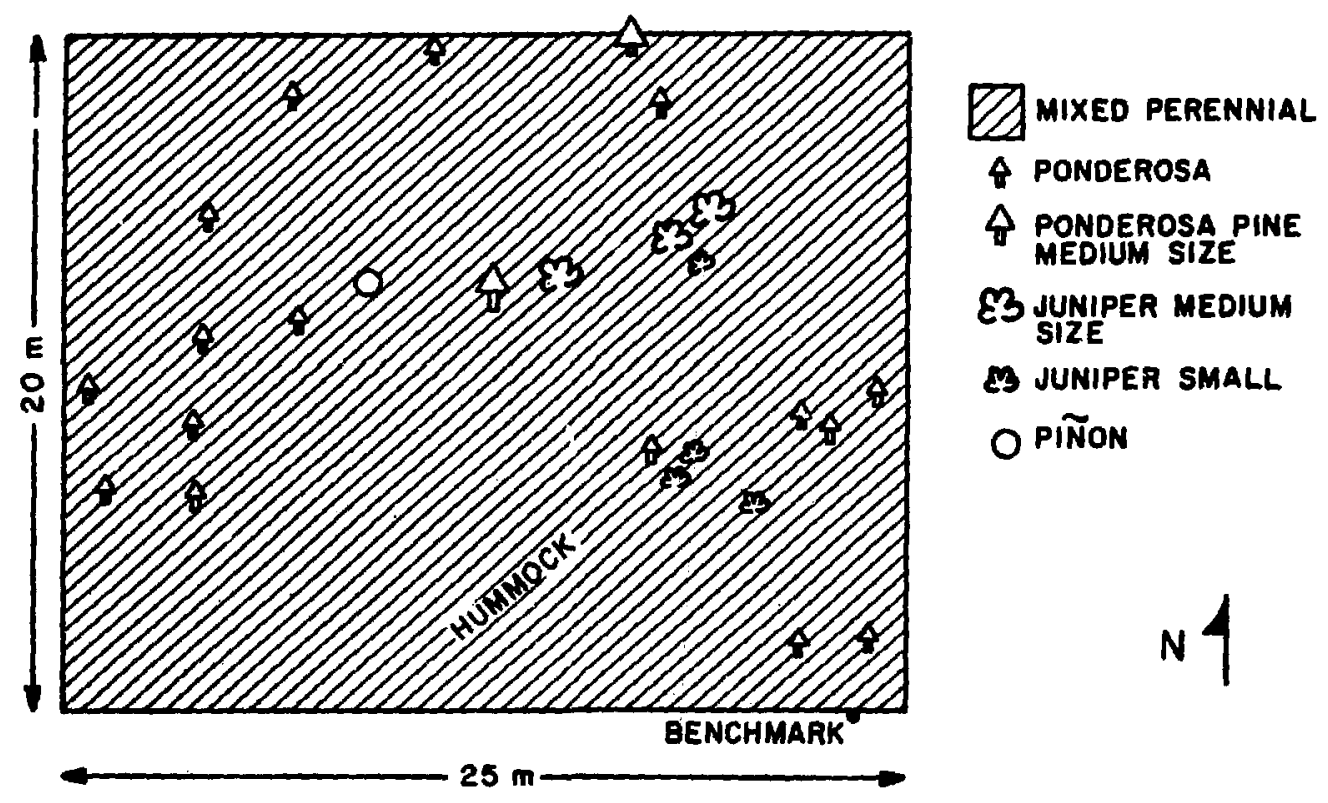

Fig. 11. Vegetation map for waste disposal site Fa. 


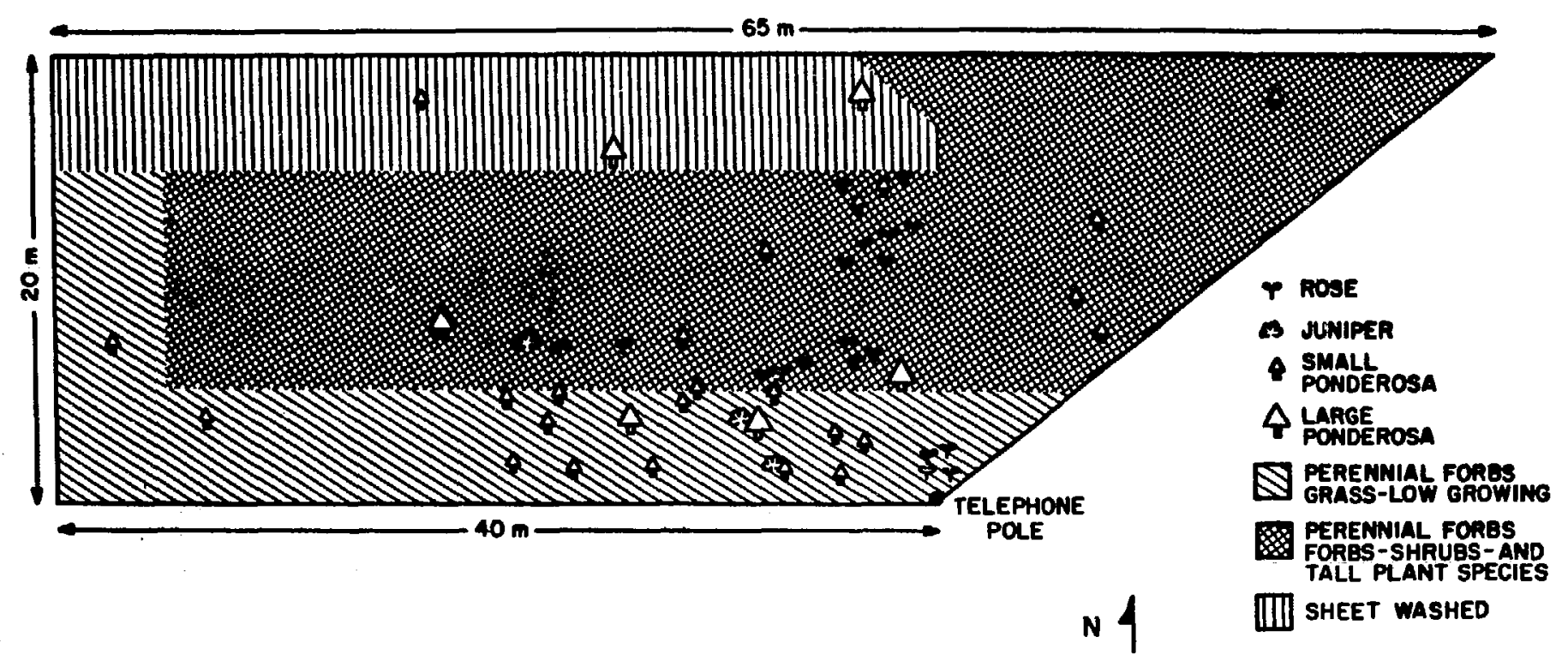

Fig. 12. Vegetation map for waste disposal fite Fb. 


\section{G. Discussion}

Both $\mathrm{Fa}$ and $\mathrm{Fb}$ are in a later seral stage, but far from climax. The agricultural field in which the sites are situated was probably established in the late 1800 s and farmed continuously until 1942 when the area was taken over for the Manhattan Project. According to Al Van Vessem, "there has been little disturbance, other than these waste disposal sites, on the old field areas since the abandonment of agriculture. $F$ site was apparently opened and closed within the year 1946, so there was no long-term disturbance. There is no evidence that the site was seeded; instead, natural succession has taken place.

Cored trees for both sites were no older than 26 yr of age, with most of the medium-sized trees being 11 to $13 \mathrm{yr}$ of age. The oldest trees were on Fb, which is closer to the forest edge.

The later seral stage is evident from the invasion of the ponderosa pine. Those of larger diameter are most closely associated with the field-forest ecotone. Trees of smaller diameter are found at a greater distance from the ecotonal area. Grasses that are common in the ponderosa pine forest are also found within the field area. These include little blue stem (Andropogon scoparius) and mountain muhly (Muhlenbergia montana). Another indicator of the successional stage is the high percentage of perennials.

Surprisingly, although the two small pits are located close together, the vegetational composition is somewhat different. The dominate species on $\mathrm{Fa}$ is wormwood, whereas on $\mathrm{Fb}$, the trailing fleabane dominates. The species diversity of these plots can be explained by several factors, including location, size, and erosional patterns. $\mathrm{Fa}$ is more closely associated with the roadside and a greater percentage of annual species is present than at Fb. Roadside species such as bahia (Bahia dissecta), gumweed (Grindelia aphanactis), and downy chess (Bromus tectorum) are found on $\mathrm{Fa}$, but not on $\mathrm{Fb}$. Site $\mathrm{Fb}$, on the other hand, is closer to the forest-field ecotone. This area has a larger number of species that are characteristically found in forested areas of the plateau, such as little blue stem, pine dropseed (Blepinaroneuron tricholepis), blue grama, and mountain muhly. Its proximity to the forest edge is important in these successional patterns.

Fa site slopes slightly to the north, and, on the northern side of the pit, there is considerable sheet washing, probably caused by differences in soil compaction. This has kept the site in a state of continual disturbance. Trailing fleabane daisy typically invades eroded sites and once established becomes profuse because of its ability to reproduce by runners. ${ }^{26}$

False terragon, an indicator of fallow agricultural areas or pasture lands, is present in both sites. The relative unimportance of this species on these sites as compared to the importance of it on $\mathbf{C}$ site is also indicative of the degree of succession that has taken place over the past $34 \mathrm{yr}$.

Studies have shown that ecotonal areas have greater species diversity. ${ }^{20}$ However, another factor must be kept in mind; these areas are small, and the species diversity may merely be because of differences in soil compaction, slope, and other similar microsite factors.

\section{DESCRIPTION OF WASTE DISPOSAL SITE G}

\section{A. Location}

Area G is located on Mesa del Buey (TA-54) about $3.2 \mathrm{~km}$ (2 mi) southeast of the intersection of the Access Road and Pajarito Road. It is west of Tsirege ruins. The township and range is $S .1 / 2$ sec. 31, T., 19N, R7E. As of July 1976, the total area was $14.8 \times 10^{4} \mathrm{~m}^{2}$ (14.8 ha).

‘Personal communication, Aug. 1980, Alan R. Van Vessem, Member of MAT-3 Division, Los Alamos National Laboratory. 


\section{B. Physied Deacription}

Mesa del Buey is formed by two canyons-Pajarito Canyon to the south and Cañon del Buey to the north. Its top is $91.4 \mathrm{~m} \mathrm{(300} \mathrm{ft)} \mathrm{above} \mathrm{these} \mathrm{canyon} \mathrm{floors.} \mathrm{The} \mathrm{mesa} \mathrm{is} \mathrm{approximately} 3 \mathrm{~km}$ ( $2 \mathrm{mi})$ long and $402 \mathrm{~m}(0.25 \mathrm{mi})$ wide. The mesa slopes southeasterly from an altitude of 2103 to $2012 \mathrm{~m}$ (6960 to $6600 \mathrm{ft}$ ). Soils are shallow, from 0.3 to $0.6 \mathrm{~m}$ ( 1 to $3 \mathrm{ft}$ ). Pits are $50 \mathrm{~m}$ (164 ft) from the edge of the mesa at a minimum.

The entire site is encompassed by chain-link fencing, and the entrance is through the TA-54 gate. The entire acreage within the fence has been disturbed and is still subject to disturbance either from trucks or mowing machines (Fig. 13).

\section{Hiatory}

The first pit was excavated in February of 1957 , but prior to that time, several archeological ruins were removed from the area. Grubbing and clearing of trees and shrubs were also completed prior to that date.

Two general areas were surveyed to correspond with small animal studies carried on with T. E. Hakonson, LS-6. The first and most easternly plot is designated $G_{1}$ and is the older of the two plots. The second is designated as $G_{3}$. Specific procectures for each area are described below.

\section{Vegetation Overview}

Area $G$ is in a high-elevation piñon-juniper plant community; that is, the piñon are the most typical overstory tree of the surrounding forest. A large portion of Mesa del Buey has been thoroughly disturbed.

\section{Aren $\mathbf{G}_{1}$}

a. Description. This area has been under constant disturbance since 1957. The final covering of the last pit (pit 5) was in March 1974. The five pits lie north to south over the length of the plot. Soils from one pit were piled upon impending excavations or old pits. There is no indication that there was any attempt at reclamation. A comment in Rozers, 1977, quoting a memo from H-1 Group Leader, dated February 9, 1973, indicates that hittle revegetation is occurring. During March 1974, a program was started by $\mathrm{H}-8$ to investigate possible avenues of revegetating these sites. 5 .

H-8 set up some $1-m(3.2-\mathrm{ft})$ experimental plots to test the fficacy of various revegetation treatments, such as rock, sewage sludge, checese cloth, and hay mulches, as soil enhancers. A seed mix containing yellow sweet clover, little blue stem, blve grama, sideoats grama, western wheatgrass, slender wheatgruss, spike muhly, sand dropseed, richgrass, and Holt Indian grass was applied at a rate of $10 \mathrm{~g} \mathrm{mix}$ for each $\mathrm{m}^{2}$ plot. Germination rates were checked in September 1977. Germination showed fair to poor success, and most plots primarily showed ative or escape species, such as blazing star (Mentzelia pumila) or Russian thistle (Salsola kali)*. The only species found on the site in 1980 that could have been from or in the seed mixture was a very small amount of rice grass. Where the rock experiments were located, clumps of vegetation were more common than in other areas.

"Notes, David R. Dreesen, Research notebook, Stuff Member, LS-6, Los Alamos National Laboratory, Nov. 1980. 
4

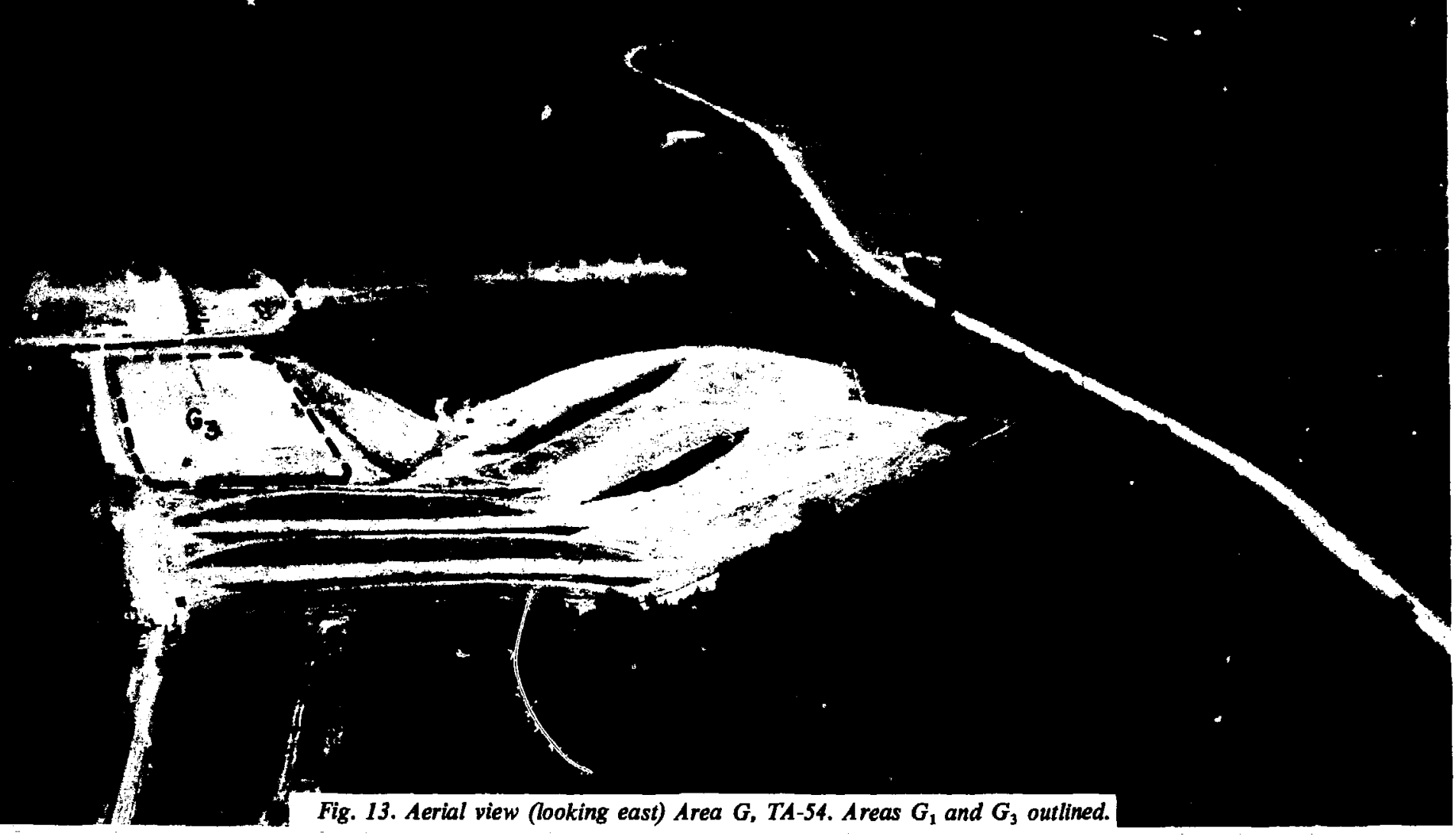


b. Procedures. Area $G_{1}$ is approximately $1 \times 10^{4} \mathrm{~m}^{2}$ ( $\left.1 \mathrm{ha}\right)$ and had been divided into $7.5-\mathrm{m}$ (24.6-ft) grids for the convenience of burrowing animal studies carried out by $T$. E. Hakonson. These grids were used to map the site on a $1.08-\mathrm{m}$ (3.5-ft) quadrat indicating the presence of chamisa, forbs, grass, or coinbinations of these. The map was then coded to be submitted to "MAPPER" for final mapping and correlation with the animal studies (Fig. 14).

The site was dissected by three transects, equally spaced, approximately $130 \mathrm{~m}$ long. They were used to determine species composition, abundance, and dominance. Fifty-four $1-\mathrm{m}^{2}\left(3.2^{2}-\mathrm{ft}\right)$ quadrats were used to determine frequency and per cent foliage cover.

c. Results. A total of 20 species was found on the $G_{1}$ waste disposal area. Of those 20 species, $15 \%$ were annuals, $40 \%$ perennials, $20 \%$ biennials, $20 \%$ shrubs, and $5 \%$ trees. Introduced species represented $10 \%$ of the total species found. Grasses made up $20 \%$ and forbs $55 \%$. The sunflower family (Compositae) was the largest represented family with $50 \%$ of the species. Grass (Graminae) made up 20\% of . the species.

The site was dominated by two varieties of chamisa ( $C$ nauseosus var. viscidiflorus and $C$. nauseosus var. latisquameus). Other vegetation had a far less importance value. Calculated importance values for other species on the site are in Table V. Much of the southern to southeastern end of the site was covered with these species. The north-northwest portion of the site had only a minimal vegetation which consisted of such forbs as nodding buckwheat (Eriogonum cernutum), rosettes of blazing star, a biennial, and some seedlings of both varieties of chamisa.

Total foliage cover for the site was $8.5 \%$ foliage cover $/ \mathrm{m}^{2}$. Chamisa made up $7 \%$ of the foliage cover $/ \mathbf{m}^{2}$.

d. Discussion. Vegetation on this site is, by far, the most sparse of any of the waste sites on the Pajarito Plateau. These pits were excavated into ash flows of the Bandelier tuff, which had a pumice zone. Pits appeared to be covered by either crushed tuff or pumice with no additional top soil added. There is no indication from Rogers ${ }^{3}$ that any reclamation was done on this site until a program was started in 1974 by H-8 "to establish needed improvements in erosion control and soil fixation." Some experimental plots were set up within this area and various types of reclamation treatments were tested. Presently, this experimental plot has relatively more vegetation than the surrounding area. Because of no soil cover and lack of germination of seeded species, the experiment was terminated.*

The site is essentially devoid of vegetation toward the north-northwest end. There are numerous tire tracks indicating much vehicular traffic. Where the tires have compacted the pumice, little vegetation is found. However, in the mounds between the tire tracks, sparse stands of nodding buckwheat or other forbs are present.

The south-southeast end of the site is being invaded by chamisa. Although this plant can be used for reclamation, there is no indication that it was seeded or planted here. This genus has the ability to become established in rather severe sites, particularly sandy or rocky, gravelly soils ${ }^{16}$ and produces numerous windblown seeds. The seed source may be the roadway below the mesa where chamisa thickets are found.

All other species recorded for the area typically are found in disturbed sites. A number are either annuals or biennials indicative of an early successional stage. This site probably would be the closest to primary sucession of any site examined.

Notes, David R. Dreesen, Research notebook, Staff Member, LS-6, Los Alamos National Laboratory, Nov. 1980. 


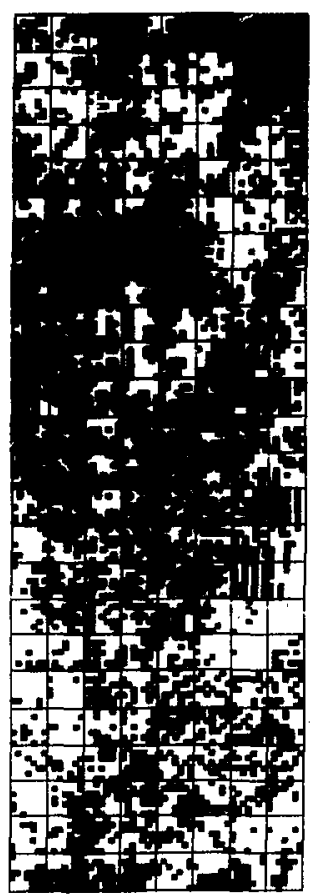

Bare Ground

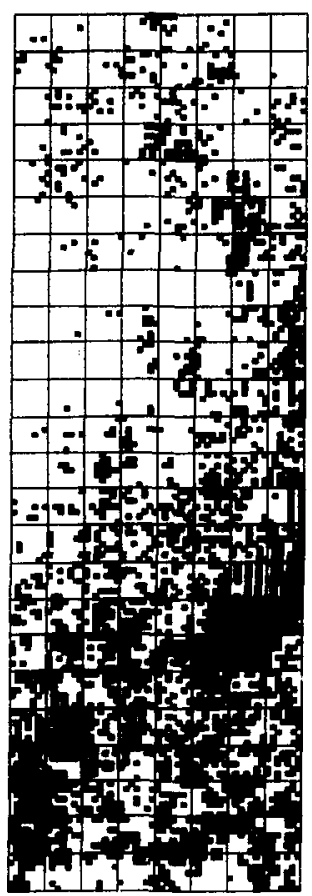

Chrysothamnus

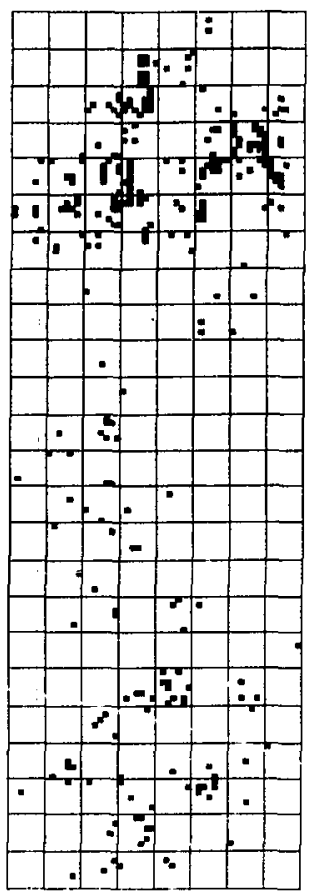

Grass

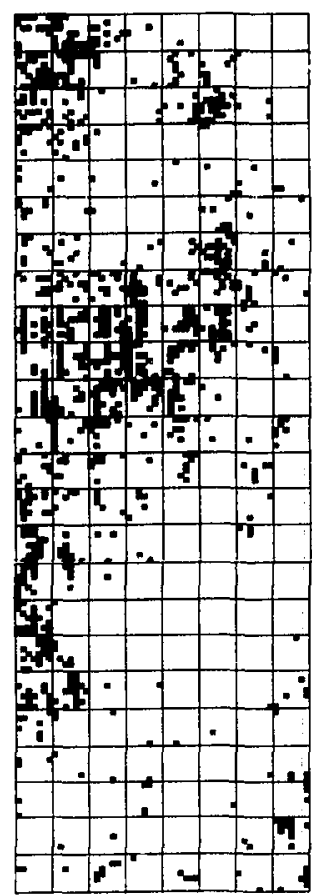

Forbs

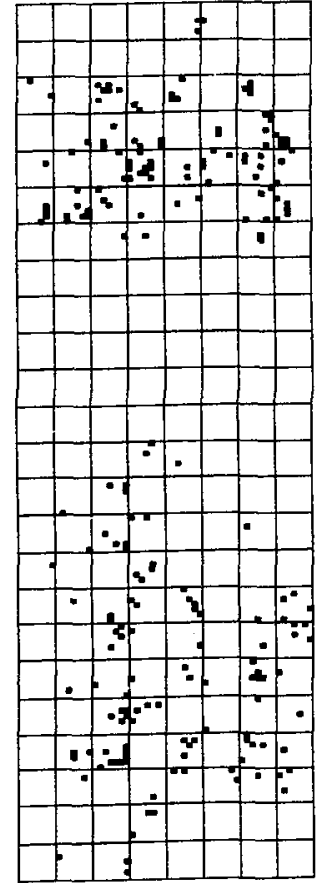

Grass-Chrysothamnus

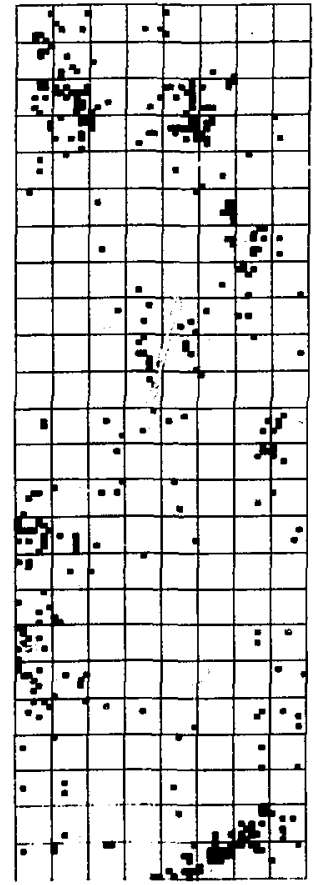

Forbs-Chrysothamnus

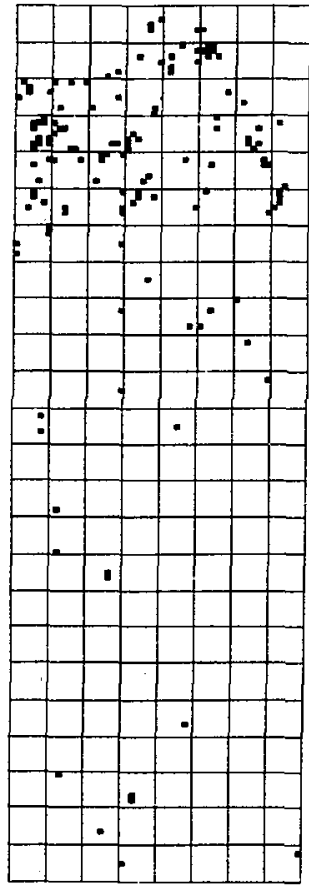

Grass-Forbs

Fig. 14. Computerized vegetation map for waste disposal site $G_{1}$. 


\section{Area $\mathrm{G}_{3}$}

a. Description. The area designated as $G_{3}$ is approximately $1 \times 10^{4} \mathrm{~m}^{2}$ (1 ha) and lies west of $G_{1}$. It slopes to the south about $15^{\circ}$ and is composed of an upper and lower unit separated by a drainage ditch. The first pit in the area was dug in 1969, and the site was closed in 1974. At that time, only crushed tuff was on the surface. The area lay fallow in this state until about 1977 when a decision was made to revegetate to hold down the dust. At that time, 10 to $15 \mathrm{~cm}$ (4 to $6 \mathrm{in}$.) of top soil were spread over the crushed tuff, and the area was seeded with a mixture of eight grasses and forbs (Table VI). Seed and fertilizer were spread by hand, covered with straw, and crimped in by the disc unit on a tractor. Where germination was poor, the area was reseeded the following year. Seed mixtures may have varied from the list given (Table VI) depending upon availability. There is no apparent record of the exact seed mixtures.*

*Personal communication, Oct. 1980, John L. Warren, Staff Member, H-7, Los Alamos National Laboratory.

\section{TABLE V}

\section{IMPORTANCE VALUES OF SELECTED SPECIES ON WASTE DISPOSAL SITES $G_{1}$ AND $G_{3}$}

\begin{tabular}{|c|c|c|}
\hline Species & Common Name & $\begin{array}{c}\text { Importance } \\
\text { Value }\end{array}$ \\
\hline \multicolumn{3}{|l|}{$\mathbf{G}_{\mathbf{1}}$} \\
\hline Chrysothamnus nauseosus & chamisa & 61 \\
\hline Eriogonum cernuum & nodding buckwheat & 12 \\
\hline Aster bigelovii & Bigelow aster & 7 \\
\hline Mentzelia pumila & white stem blazing star & 7 \\
\hline Buchloe dactyloides & buffalo grass & 6 \\
\hline Chrysopsis villosa & leafy golden aster & 3 \\
\hline Oryzopsis hymenoides & rice grass & 3 \\
\hline Bahia dissecta & bahia & 2 \\
\hline Salsola kali & Russian thistle & 2 \\
\hline Kochia scoparia & summer cypress & 0.9 \\
\hline Senecio multicapitatus & groundsel & 0.4 \\
\hline \multicolumn{3}{|l|}{$G_{3}$} \\
\hline Sporobolus cryptandrus & sand dropseed & 19 \\
\hline Melilotus spp. & sweet clover & 19 \\
\hline Festuca spp. & fescue & 18 \\
\hline Aster bigelovii & Bigelow aster & 16 \\
\hline Grindelia aphanactis & gum weed & 7 \\
\hline Ambrosia spp. & ragweed & 7 \\
\hline Artemisia dracunculus & false terragon & 3 \\
\hline Bouteloua gracilis & blue grama & 3 \\
\hline Kochia scoparla & summer cypress & 3 \\
\hline Salsola kali & Russia thistle & 1 \\
\hline Gutierrezia microcephala & sriakeweed & 0.5 \\
\hline Agropyron spp. & wheat grass & 0.3 \\
\hline
\end{tabular}




\section{TABLE VI}

\section{REVEGETATION SEED MIXTURE FOR G3 WASTE DISPOSAL SITE}

\begin{tabular}{l}
\multicolumn{1}{c}{ Species } \\
\hline Oryzopsis hymenoldes \\
Andropogon scoparius \\
Agropyron smithil \\
Bouteloun curtipendula \\
Mellotus officinalis \\
Buchloë dactyliodes \\
Lelium perenne
\end{tabular}

\begin{tabular}{l} 
Common Name \\
\hline Indian rice \\
little blue-stem \\
western wheatgrass \\
side oats grama \\
yellow blossom clover \\
buffalo grass \\
perennial rye
\end{tabular}

b. Procedures. The area was divided into $7.5-\mathrm{m}(24.6-\mathrm{ft})$ grids for the convenience of small animal studies carrie J out by T. E. Hakonson. These grids were used to map the site on a $1.07-\mathrm{m}$ (3.5-ft) quadrat, indicating the presence of sweet clover, forbs, grass, or a combination of these. The map was then coded to be submitted to "MAPPER" for final mapping and correlation with animal studies (Fig. 15).

The site was dissected by two $100-\mathrm{m}(328-\mathrm{ft})$ transects. These transects were used to determine species composition density and dominance. A total of 20 meter-by-meter (3.2- $\times 3.2-\mathrm{ft})$ quadrats were used to determine frequency and per cent foliage cover.

c. Results. A total of 25 species were recorded along the transects or within the plots. Of these 25 species, $40 \%$ were annuals, $40 \%$ perennials, $16 \%$ biennials, and $4 \%$ shrubs. No trees were found on the site. Introduced species represented $16 \%$ of the total species on the site. Grasses made up $24 \%$, forbs $72 \%$, and shrubs $4 \%$. The sunflower (Compositae) family had the largest representation with $40 \%$ of the total species. Grasses were $24 \%$ of the total.

The site was dominated by artifically seeded species, including sand dropseed and sweet clover. Bigelow aster (Aster bigelovii) also made up an important portion of the vegetation. Calculated importance values for these and other species in the plots are found in Table $V$. Total vegetative cover was $22.7 \%$, with the greatest foliage cover represented by sand dropseed, sweet clover, and fescue.

d. Discussion. This site is in an early seral stage. The revegetation procedures have reduced the time necessary for the area to go from primary succession to secondary succession. $G_{3}$ has the greatest number of annuals and biennials of any of the sites examined and the greatest percentages of introduced species. This is probably because of the disturbance and successional stage, and the revegetation with introdiced species, such as sweet clover.

The foliage cover was difficult to estimate on this site because of the infestation of grasshoppers and their grazing on forbs, such as sweet clover. The lateness of the season precluded good estimates for some of the grasses. Foliage cover estimates should be repeated sometime in the early summer. 


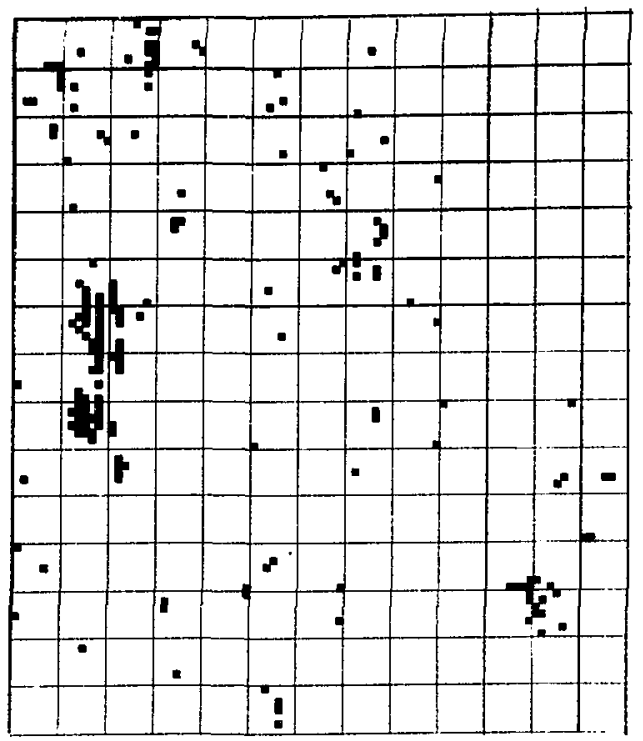

Bare Ground

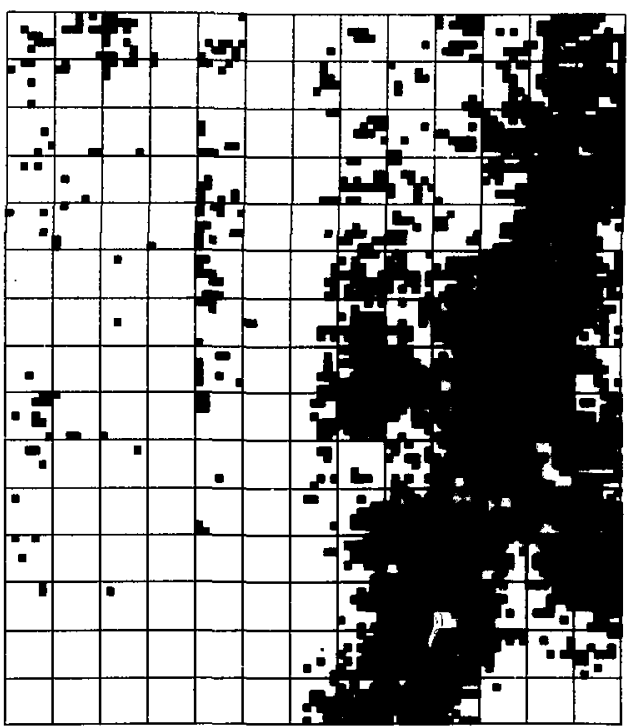

Melilotus-Grass

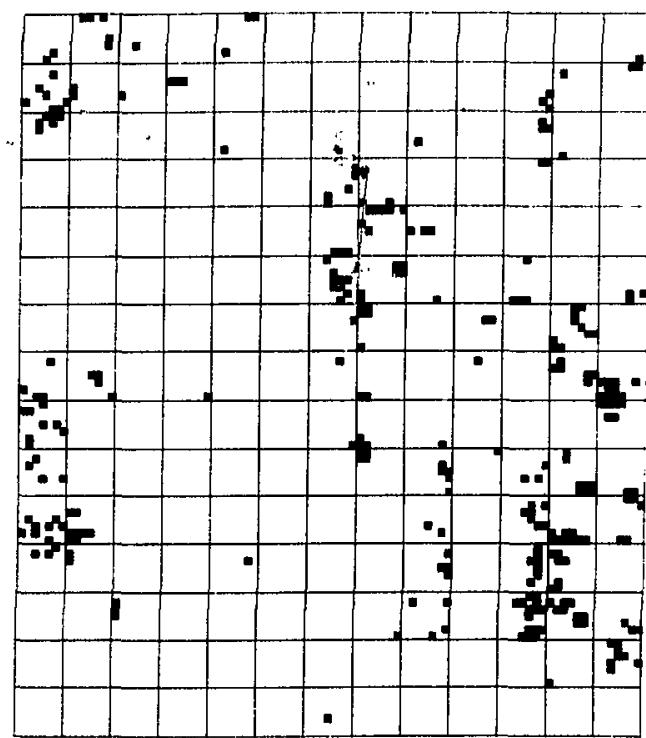

Melilotus

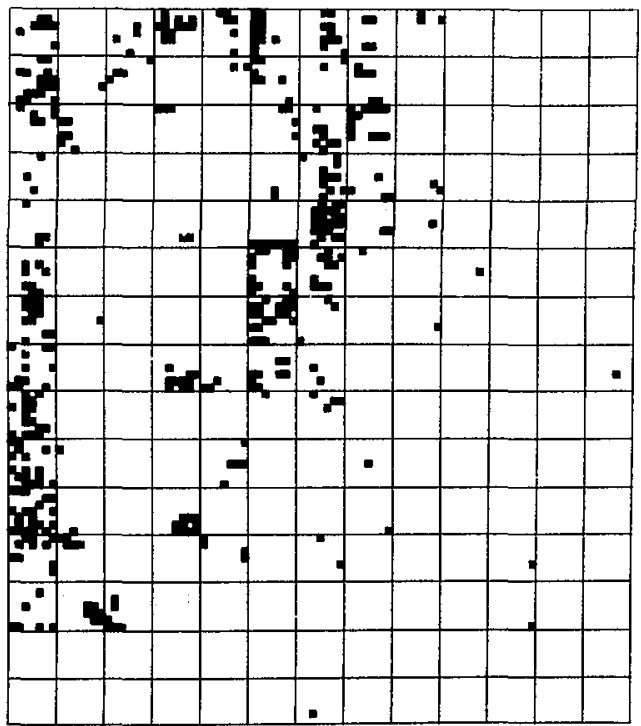

Melllotus-Forbs

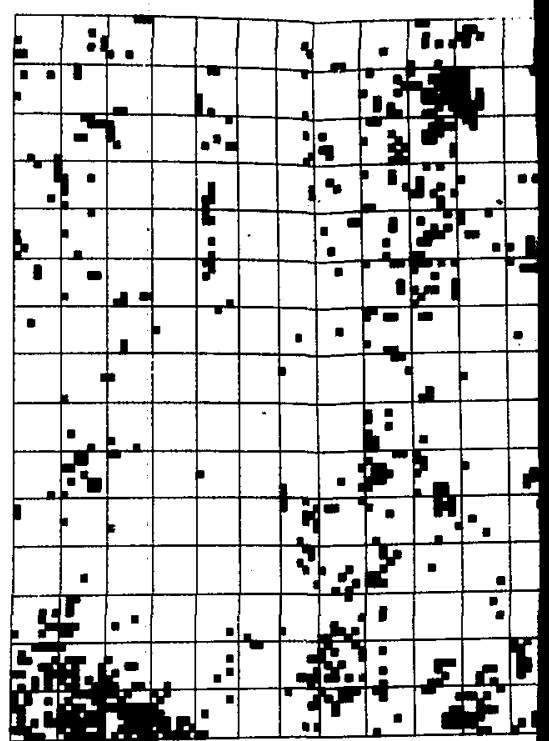

Grass

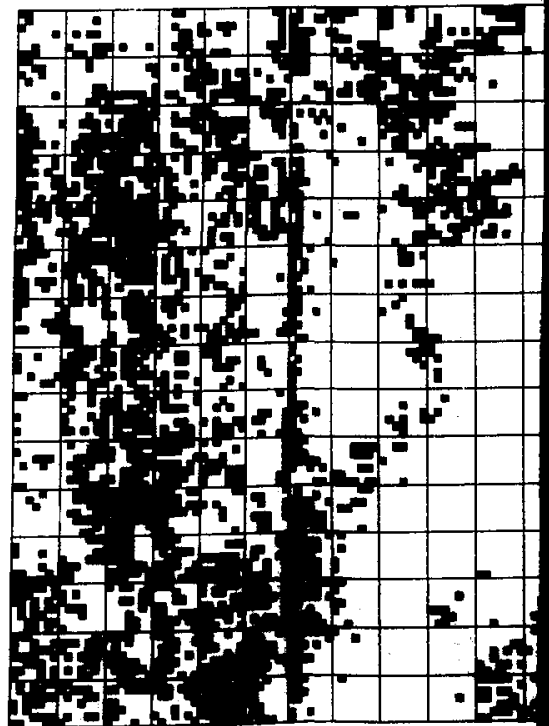

Grass-Forbs

Fig. 15. Computerized vegetation map for waste disposal sile $G_{3}$ 


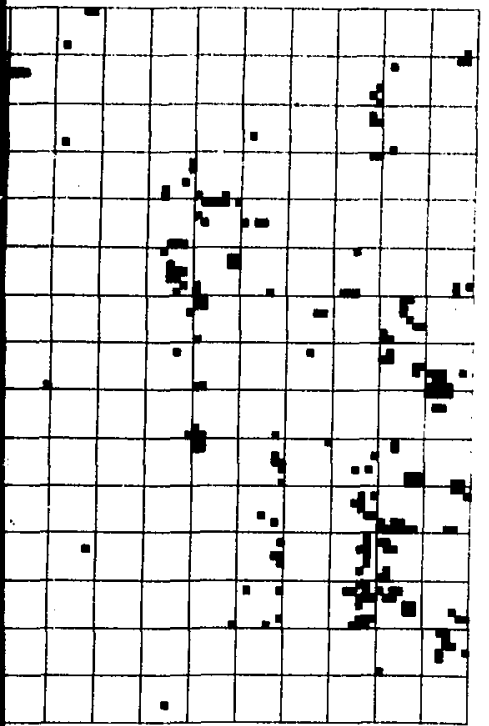

Melilotus

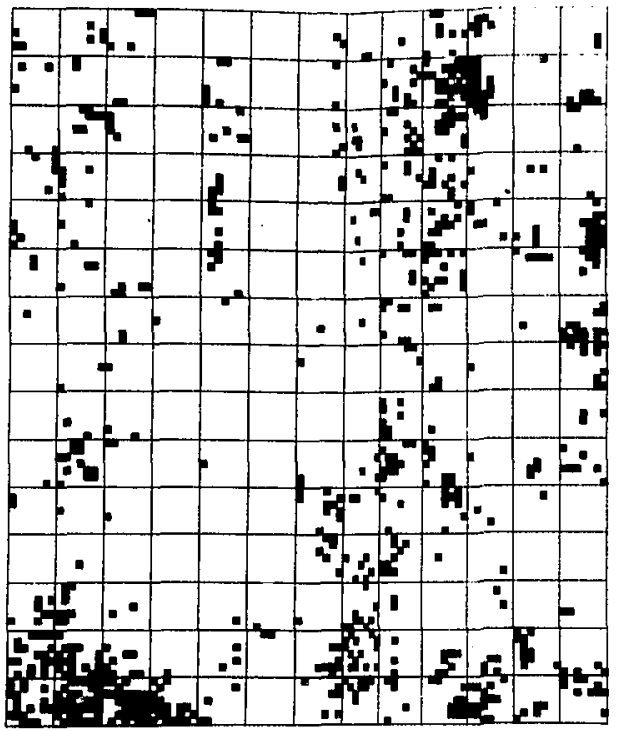

Grass

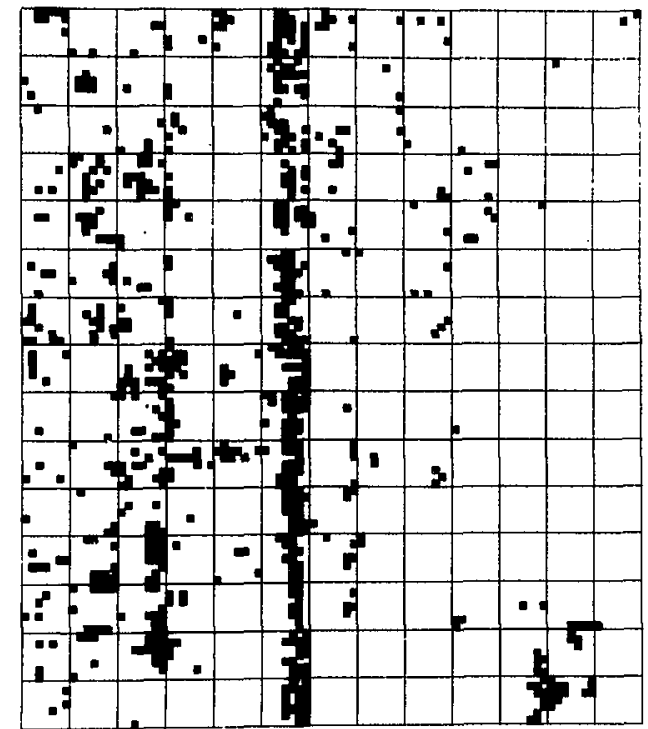

Forbs

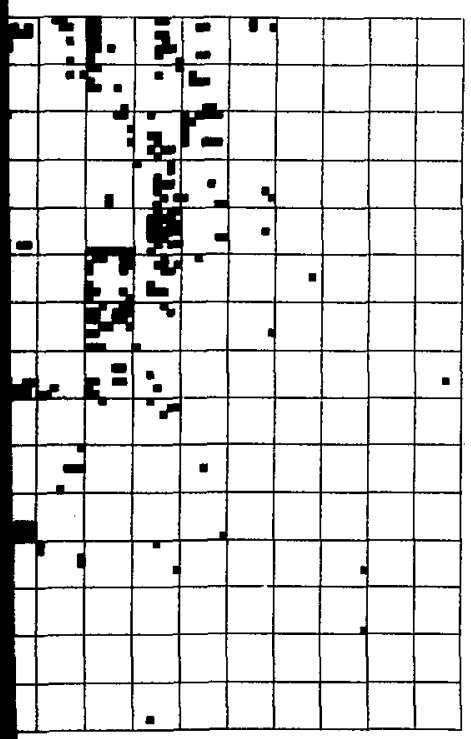

Melllotus-Forbs

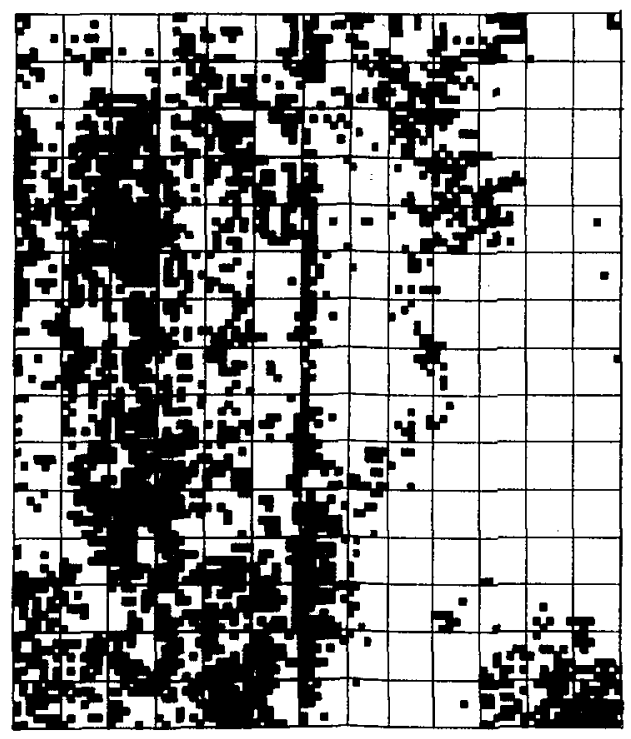

Grass-Forbs

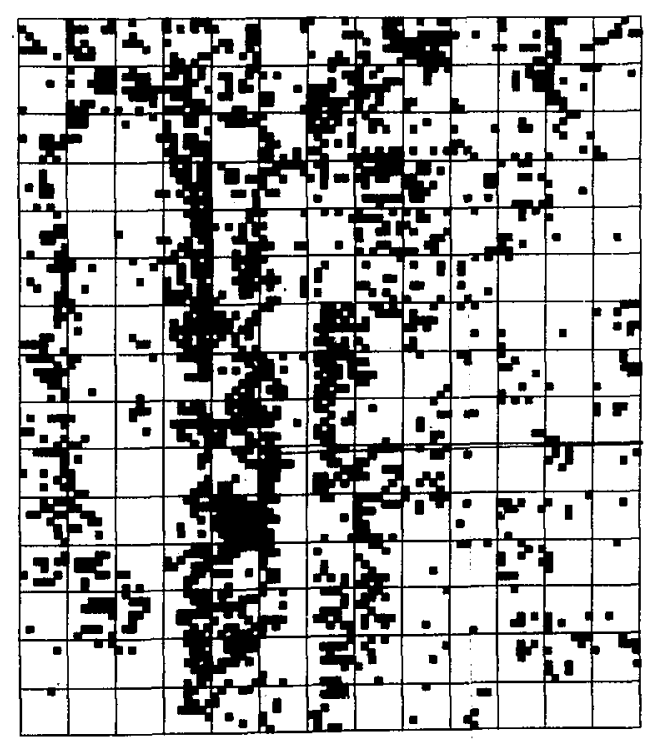

Melilotus-Grass-Forbs

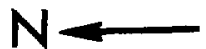

Fig. 15. Computerized vegetation map for waste disposal site $G_{3}$. 


\section{LOS ALAMOS EXPERIMENTAL ENGINEERED WASTE BURIAL FACILITY}

At the request of Gerald DePoorter, ${ }^{*}$ this area was surveyed on October 28,1980 , for the presence of rare, endangered, or threatened species. $A$ list of species found in the area was tabulated and a qualitative ranking given. A letter report describing the vegetation at this site is given in Appendix $\mathbf{C}$.

The site is located off Pajarito Road to the north. It is west of the access road to $G$ site and encompasses approximately $8 \times 10^{4} \mathrm{~m}^{2}(8 \mathrm{ha})$.

\section{SUMMARY}

\section{A. Discussion of Successional Trends}

After disruption of existing vegetation, the invasion, colonization, and re-establishment of vegetation usually follows a general pattern, whether in abandoned fields, along roadsides, on waste sites, or on mine spoils. Where woody plants are dominant, ${ }^{20-23}$ succession proceeds from early stages dominated by annuals and progresses towards later stages. Costello ${ }^{24}$ reported the following general tendencies when observing succession in abandoned fields: (1) replacement of annuals by perennials, (2) gradual reduction in per cent composition dominated by forbs, (3) increasing abundances of grasses, and (4) increased density of ground cover as climax association is approached. Finally, he found succession is accompanied by an increase in floristic diversity. The rate of recovery and species composition of the vegetation is dependent on a number of factors that may include: size of disturbed area, proximity to seed source, soil type, and climate.

The initial invasion into a disturbed site is generally of hardy annual species that are capable of surviving under extreme conditions. Such species are generally xerophytic, have prodigous seed production, a short life cycle, and advantageous means of dispersal. Once these annuals are established, they may continue to persist but decline in importance in the community.

After the initial invasion, each subsequent stage modifies the microclimate with improvement in soil structure, water retention, release of nutrients, and increased shading. Subsequent stages are generally more deeply rooted species such as perennial forbs and woody plants. Eventually, the site will be restored to the elements of the pre-existing vegetation, but this may take many years.

\section{B. Results and Discussion}

1. Succescion as Related to Life Form. The data were analyzed to see if there was any correlation between length of time since closure of the sites and life forms. Figure 16 shows the percentage of species on each site: annuals, perennials, biennials, shrubs, and trees. Data show the more recent the site, the more pronounced the downward trend in the number of perennisal species and upward trend in number of annual species. There is, however, no clear cut successional trend. The reason for this lack of trend is because parts of most of the sites are continuously disturbed by erosion, and, therefore, annuals and biennials dominate these areas.

Although these trends are not decisive, there is an inverse relationship between shrubs and biennials. Where shrub species are high in numbers, biennial species are bw in numbers. This may be because of increased competition, microclimate, etc. As the successional stages proceed toward woody plants, factors such as shading, allelochemics, and water needs may affect the ratio. 2

*Gerald DePoorter, reference letter and brief report, Dec, 1, 1980, Appendix V. 


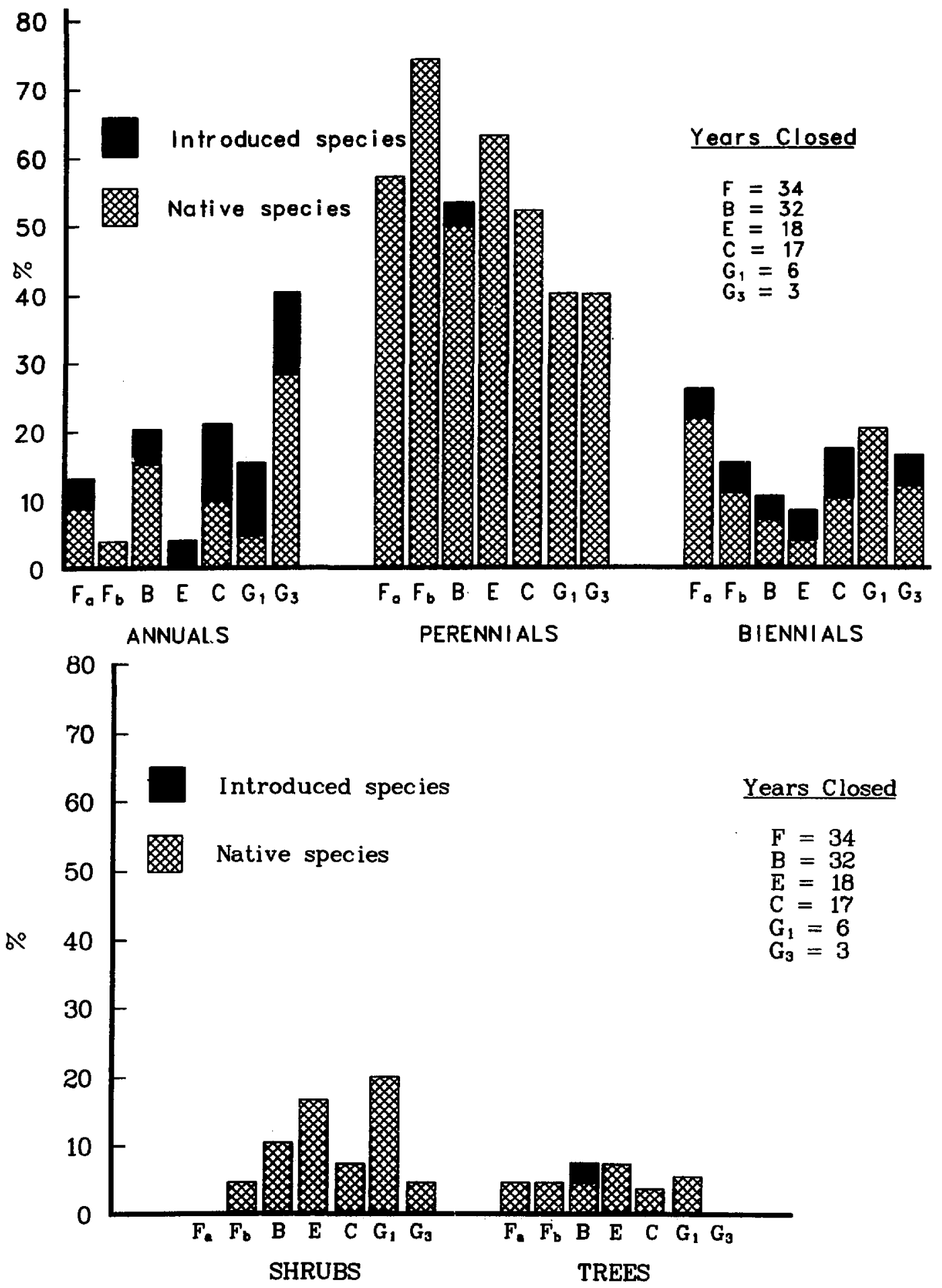

Fig. 16. Percentage of specles in lifeform categories for six waste disposal sites. 
If successional trends are present, the number of grass species can be expected to increase in numbers with time since closure and the number of forb species can be expected to decrease. Figure 17 shows the relationship of the grass, forb, shrub, and tree species as related to time since closure. Again, no clear-cut trends can be seen, and in fact, the opposite of what might be expected is found. Neither is there any relationship between the length of time since closure and the per cent composition of the dominate families, such as the sunflower family or grass family (Fig. 18). Again, this is probably because of sitespecific conditions.

2. Summary of Foliage Cover Data. When the per cent foliage cover is analyzed, the oldest sites, other than B, do not have any significant differences in per cent foliage cover (Table VII). The most recent site $\left(G_{3}\right)$ has been artifically revegetated and, therefore, cannot be considered in successional trends. Certainly the site with the lowest per cent foliage cover $\left(G_{1}\right)$ is closest to primary succession, and the site that has the highest per cent foliage cover (B) is closest to climax.

3. Species Composition. When species composition for all six sites is examined, with the exception of $B$ and $G_{1}$, nearly all have the same number of species (Table VIII). From a floristic composition or species diversity point of view, $B$ is the greatest with 58 species and $G_{1}$ the least with 20 . B is the closest to climax and $G_{1}$ the closest to primary succession.

Importance values vary considerably from site to site, with different species being most important on each site. Area B is the only site that has many plants characteristic of climax (perennial grasses, shrubs, and trees). For all other sites, plants with the highest importance value are generally invader species into disturbed soils. Table IX summarizes the importance values for the dominant species for all sites. Species that are characteristically found as initial invaders on disturbed sites are marked with an asterisk (*); those that are generally subsequential invaders are marked with a dagger $(t)$. Sites that have lain fallow the longest have more species that are secondary invaders (seral stage vegetation) than do sites $G_{1}$ or $G_{3}$.

4. General Comments. Successional trends on the six waste disposal sites are not well defined. The two oldest sites have the largest percentages of tree species. One of the better indicators of the successional trend is the size of the trees on these sites. Observations show that trees on the older sites (F and B) are large and may produce seed, whereas those on the more recent sites E, C, and $G_{1}$ are small, indicating more recent invasion and earlier stages in succession. Larger trees on B and F were 27 yr or younger.

Successional trends show a long-term return of the site to the surrounding vegetational state. Present revegetation procedures are not geared to re-establishment of the native flora but merely soil stabilization.

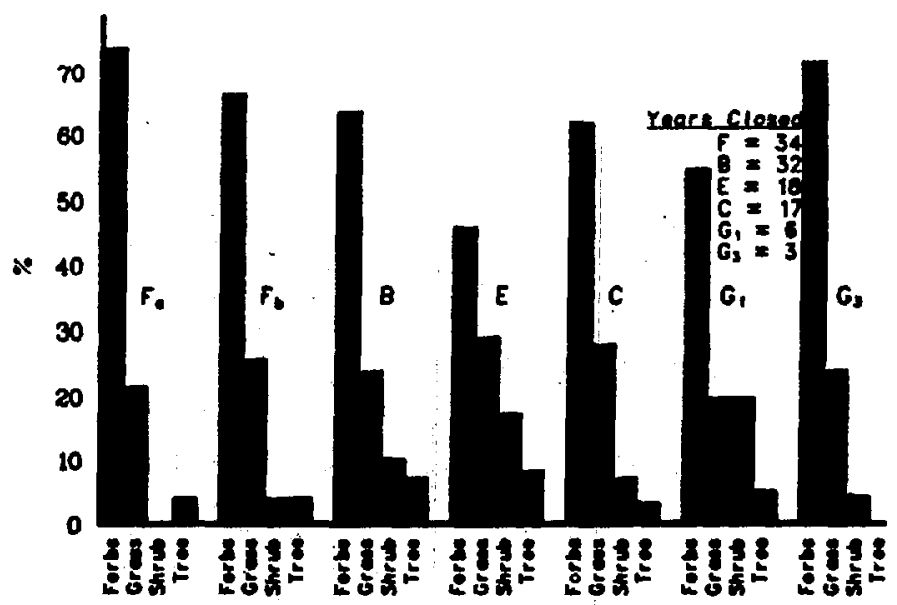

Fig. 17. Per cent of species in growth classes for six sites. 


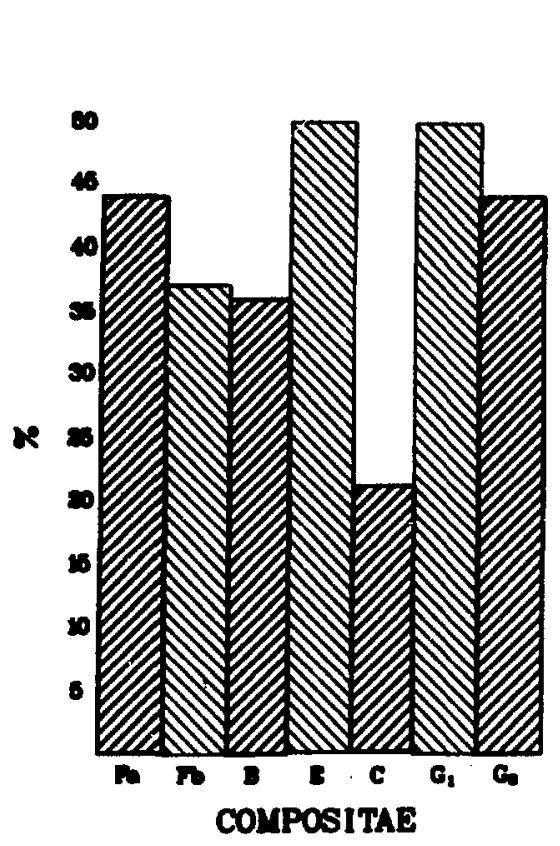

Time site clond (rmon)

$P=34$

$\mathrm{B}_{\mathrm{x}=18}$

C=17

$\mathrm{Gr}_{\mathrm{g}}=\mathbf{3}$

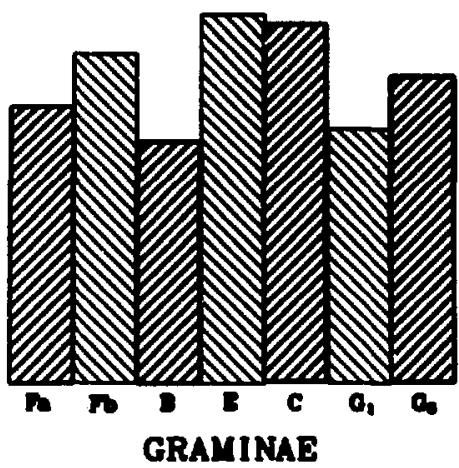

Fig. 18. Percentage of species in two floristic families in six plots (waste disposal sites).

TABLE VII

TOTAL PER CENT FOLIAGE COVER PER $\mathrm{m}^{2}$ OF ALL SIX SITES IN ORDER OF SITE CLOSURES

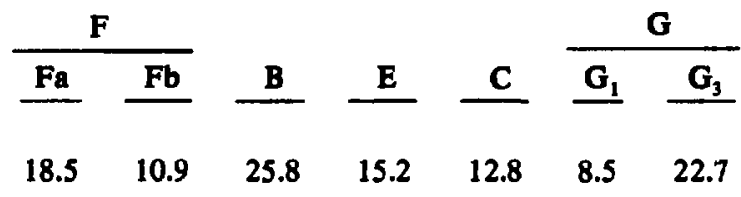

TABLE VIII

NUMBERS OF PLANT SPECIES FOUND ON SIX WASTE DISPOSAL SITES

$\underline{F a} \quad \underline{F b} \quad \underline{B} \quad \underline{E} \quad \underline{C} \underline{G_{1}} \underline{G_{3}}$

$\begin{array}{llllllll}23 & 27 & 59 & 24 & 29 & 20 & 25\end{array}$ 
TABLE IX

\section{COMPARISON OF IMPORTANCE VALUE* OF DOMINANT PLANT SPECIES ON SIX WASTE DISPOSAL SITES}

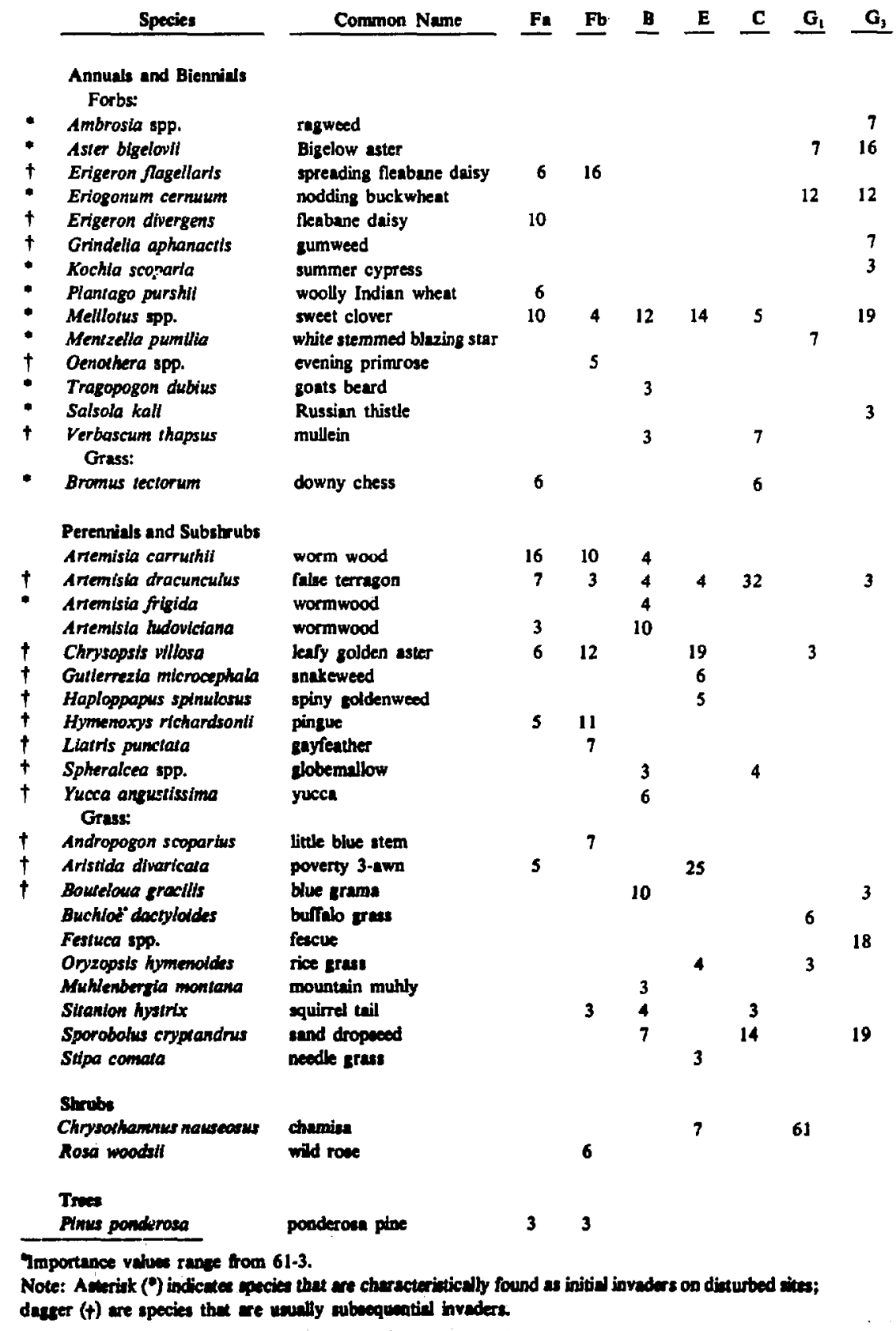




\section{ACKNOWLEDGMENTS}

We would like to thank Wayne Hansen, Group Leader, $\mathrm{H}-8$, for his support and guidance in this project; Tom Hakonson, LS-6, for his suggestions improving the design of the project to make it more applicable to biointrusion studies; Gary White, LS-6, for the superb MAPPER computer graphics; Joel Williams, LS-6, for much help with the other computer graphies; Roger Ferenbaugh, H-8, for his perceptive editing; and Kathy Derouin for her patience and talent in the typesetting, layout, and general production of this report.

\section{REFERENCES}

1. Environmental Protection Agency Federal Register 46, (January 9, 1981), 2556-2563.

2. Nuclear Regulatory Commission Federal Register 45, (October 3, 1980), 65533-65536.

3. W. L. Wagner, W. C. Martin, and E. F. Aldon, 1978, "Natural Succession on Strip-Mined Lands in Northwestern New Mexico," in Reclamation Review, Vol. I (Pergamon Press, Inc., Elmsford, New York).

4. T. E. Hakonson, "Evaluation of Erosion and Intrusion Control Barriers for Low-Level Waste," Proposal to the Department of Energy, Division of Waste Management, Los Alamos Scientific Laboratory, Los Alamos, New Mexico (1980).

5. M. A. Rogers, "History and Environmental Setting of LASL Near-Surface Land Disposal Facilities for Radioactive Wastes (Areas A, B, C, D, E, F, G, and T), A Source Document," Los Alamos Scientific Laboratory report LA-6848-MS, Vol. I, Los Alamos, New Mexico(June 1977).

6. T. S. Foxx and G. D. Tiernev, "Status of the Flora of the Los Alamos National Environmental Research Park," Los Alamos Scientific Laboratory report LA-8050-NERP, Vol. I (May 1980) (Vol. II in preparation).

7. T. S. Foxx and G. D. Tierney, "Status of the Flora of the Los Alamos National Environmental Research Park," Los Alamos National Laboratory (Vol. III in preparation, 1981).

8. Environmental Surveillance (H-8), "The Los Alamos National Environmental Research Park," Los Alamos National Laboratory, Contract W-7405-Eng. 36.

9. A. W. Kuchler, Vegetation Mapping (The Ronald Press Co., New York, 1967).

10. E. A. Phillips, Methods of Vegetation Study (Holt, Rinehart \& Winston, Inc., New York 1959).

11. K. Kershaw, Quantitative and Dynamic Plant Ecology (American Elsevier Publishing Co., New York (1973).

12. W. B. MacDougall, Seed Plants of Northern Arizona, Museum of Northern Arizona, Flagstaff (1973).

13. W. C. Martin, C. R. Hutchins, and R. L. Woodmanse, A Flora of the Sandia Mountains, Department of Biology, The University of New Mexico (1970). 
14. N. D. Harrington, Manual of the Plants of Colorado (Swallow Press, Inc., Chicago, 1964).

15. T. H. Kearney and R. H. Peebles, Arizona Flora, 2nd ed., (University of California Press, Berkeley, 1964).

16. U.S. Department of Agriculture, Range Plant Handbook, U.S. Department of Agriculture, Forest Service, Washington, D.C. (1937).

17. T. S. Foxx and L. D. Potter, "Fire Ecology at Bandelier National Monument," Final Report, National Park Service, Santa Fe, New Mexico (1978).

18. J, H. Abrahams, Jr., "Geologic and Hydrolic Environment of Radioactive Waste-Disposal Sites at Los Alamos, New Mexico," U.S. Geol. Survey Administrative Release (1963).

19. W. Crocker, "Life-Spar of Seeds," in The Botanical Review, Vol. 4 (1938).

20. R. H. Whittaker, Communities and Ecosystems, 2nd ed. (Macmillan Publishing Co., Inc., New York, 1975).

21. F. E. Clements, Plant Succession, an Analysis of the Development of Vegetation, Carnegie Inst. Wash. Publ. 242 (1916).

22. I. B. Judd, "Plant Succession on Old Fields in the Dust Bowl," Southwestern Naturalist, Vol. 19, No. 3 (September 23, 1974).

23. J. L. Launchbaugh, "Vegetational Changes in the San Antonio Prairie Associated with Grazing and AbandJninent from Cultivation," Ecological Monographs, Vol. 25, No. 1 (January 1955).

24. D. F. Costello, "Natural Revegetation of Abandoned Plowed Land in the Mixed Prairie Association of Northeastern Colorado," Ecology, Vol. 25, No. 3 (July 1944).

25. N. E. West and P. T. Tueller, "Special Approaches to Studies of Competition and Succession in Shrub Communities," in Willand Shrub-Their Biology and Utilization, USDA Forest Service General Technical report INT-1, Intermountain Forest and Range Experiment Station, Ogden, Utah (1972). 
APPENDIX A

ROOT DEPTHS OF THREE SPECIES FOUND ON WASTE DISPOSAL SITES

\begin{tabular}{|c|c|}
\hline Species & $\begin{array}{c}\text { Root Depths } \\
\text { (mm) }\end{array}$ \\
\hline \multirow[t]{4}{*}{ Artemisia carruthii } & 105 \\
\hline & 80 \\
\hline & 150 \\
\hline & 120 \\
\hline \multirow[t]{2}{*}{ Chrysopsis villosa } & 210 \\
\hline & 240 \\
\hline \multirow[t]{5}{*}{ Hymenoxys richardsonii } & 225 \\
\hline & 140 \\
\hline & 205 \\
\hline & 300 \\
\hline & 215 \\
\hline
\end{tabular}


APPENDIX B

ANNOTATED CHECKLIST OF PLANTS ON WASTE DISPOSAL SITES

\begin{tabular}{|c|c|c|c|c|c|c|c|c|c|c|c|}
\hline Species & Common Name & Habit & Origin & $\underline{\mathbf{B}}$ & $\underline{\mathbf{C}}$ & $\underline{\mathbf{E}}$ & $\underline{\mathbf{F a}}$ & $\mathbf{F b}$ & $\underline{\mathbf{G}_{1}}$ & $\underline{\mathbf{G}_{3}}$ & $\begin{array}{c}\text { Experimental } \\
\text { Waste } \\
\text { Site } \\
\end{array}$ \\
\hline $\begin{array}{l}\text { AMARANTHACEAE } \\
\text { Amaranthus spp. }\end{array}$ & $\begin{array}{l}\text { amaranth family } \\
\text { amaranth }\end{array}$ & $\mathbf{A}$ & $\mathbf{N}$ & & & & & & & $\mathbf{x}$ & \\
\hline $\begin{array}{l}\text { ANACARDIACEAE } \\
\text { Rhus trilobata }\end{array}$ & squaw bush & & & $\mathbf{x}$ & & & & & & & \\
\hline BORAGINACEAE & borage family & & & & & & & & & & \\
\hline Cryptantha jamesii & hidden flower & $\mathbf{P}$ & $\mathbf{N}$ & $\mathbf{x}$ & $x$ & & & & & & $\mathbf{x}$ \\
\hline Lappula spp. & stickseed & $\mathbf{A}$ & I & $\mathbf{x}$ & $x$ & & & & & & \\
\hline $\begin{array}{l}\text { Lithospermum } \\
\text { mulifforum }\end{array}$ & puccoon & $\mathbf{P}$ & $\mathbf{N}$ & $\mathbf{x}$ & & & & $\mathbf{x}$ & & & \\
\hline CACTACEAE & csctus family & & & & & & & & & & \\
\hline Opuntla spp. & prickly pear & $\mathbf{P}$ & $\mathbf{N}$ & $\mathbf{x}$ & & & & & & & $\mathbf{x}$ \\
\hline Opuntia imbricata & walking stick cactus & $\mathbf{P}$ & $\mathbf{N}$ & & & & & & & & $\mathbf{x}$ \\
\hline Corypanthe vivipara & pincushion cactus & $\mathbf{P}$ & $\mathbf{N}$ & $\mathbf{x}$ & & & & & & & $\mathbf{x}$ \\
\hline CHENOPODIACEAE & goose foot family & & & & & & & & & & \\
\hline Atriplex canescens & four-wing saltbush & $\mathbf{S}$ & $\mathbf{N}$ & & & $\mathbf{x}$ & & & & & \\
\hline Kochia scoparia & summer cypress & $\mathbf{A}$ & I & $\mathbf{x}$ & $\mathbf{x}$ & & & $\mathbf{x}$ & & $\mathbf{x}$ & \\
\hline Salsola kali & Russian thistle & $\mathbf{A}$ & I & $\mathbf{x}$ & $\mathbf{x}$ & & & & $\mathbf{x}$ & & \\
\hline Chenopodium spp. & lamb's quarters & $\mathbf{A}$ & $\mathbf{N}$ & & $x$ & & & & & $\mathbf{x}$ & \\
\hline COMPOSITAE & sunflower family & & & & & & & & & & \\
\hline Ambrosia spp. & ragweed & $\mathbf{A}$ & $\mathbf{N}$ & & & & & & & $\mathbf{x}$ & \\
\hline Artemisla carruthii & wormwood & $\mathbf{P}$ & $\mathbf{N}$ & $\mathbf{x}$ & $\mathbf{x}$ & & $\mathbf{x}$ & $\mathbf{x}$ & & & $\mathbf{x}$ \\
\hline Artemisia dracunculoides & false terragon & $\mathbf{P}$ & $\mathbf{N}$ & $\mathbf{x}$ & $\mathbf{x}$ & $x$ & $\mathbf{x}$ & $\mathrm{x}$ & $\mathbf{x}$ & $\mathbf{x}$ & \\
\hline $\begin{array}{l}\mathbf{A}=\text { annual } \\
\mathbf{B}=\text { Biennial }\end{array}$ & & $\begin{array}{l}\mathbf{S}=\text { Shru } \\
\mathbf{T}=\text { Tree }\end{array}$ & & & & & & & $\begin{array}{l}=\mathbf{N} \\
=\mathbf{I n}\end{array}$ & $\begin{array}{l}\text { ive } \\
\text { duced }\end{array}$ & \\
\hline
\end{tabular}


APPENDIX B (cont)

\begin{tabular}{|c|c|c|c|c|c|c|c|c|c|c|c|}
\hline Species & Common Name & Habit & Origin & $\underline{\mathbf{B}}$ & c & $\underline{\mathbf{E}}$ & Fa & $\mathbf{F b}$ & $\underline{G_{1}}$ & $\mathbf{G}_{3}$ & $\begin{array}{c}\text { Experimentel } \\
\text { Watte } \\
\text { Site } \\
\end{array}$ \\
\hline Artemisia frigida & estafiata & $\mathbf{P}$ & $\mathbf{N}$ & $\mathbf{x}$ & & & & & & & $\mathrm{x}$ \\
\hline Artemisia ludoviciana & wormwood & $\mathbf{P}$ & $\mathbf{N}$ & $\mathbf{x}$ & & $\mathbf{x}$ & $\mathrm{x}$ & $\mathbf{x}$ & & & $\mathrm{x}$ \\
\hline Aster bigelovii & Bigelow Aster & B & $\mathbf{N}$ & $\mathbf{x}$ & & & & & $\mathrm{x}$ & $x$ & \\
\hline Bahia dissecta & bahia & B & $\mathbf{N}$ & $\mathrm{x}$ & & $\mathrm{x}$ & $\mathbf{x}$ & $\mathbf{x}$ & $\mathrm{x}$ & $\mathbf{x}$ & $\mathrm{x}$ \\
\hline Chrysopsis villosa & leafy golden aster & $\mathbf{P}$ & $\mathbf{N}$ & $\mathbf{x}$ & $\mathbf{x}$ & $\mathbf{x}$ & $\mathbf{x}$ & $\mathbf{x}$ & $\mathbf{x}$ & $\mathbf{x}$ & \\
\hline Chrysothamnus nauseosus & chamisa & $s$ & N & $\mathbf{x}$ & & $\mathbf{x}$ & & & $\mathbf{x}$ & $\mathbf{x}$ & $\mathbf{x}$ \\
\hline $\begin{array}{l}\text { Chrysothamnus nauseosus } \\
\text { var. latisquameus }\end{array}$ & chamisa & $s$ & $\mathbf{N}$ & $\mathbf{x}$ & & & & & $\mathbf{x}$ & & \\
\hline $\begin{array}{l}\text { Chrysothamnus nauseosus } \\
\text { var, viscidiflorus }\end{array}$ & chamisa & $s$ & $\mathbf{N}$ & & & & & & $\mathbf{x}$ & & \\
\hline Circium spp. & thistle & $\mathbf{A}$ & $\mathbf{N}$ & $\mathbf{x}$ & & & & & $\mathbf{x}$ & & \\
\hline Conyza canadensis & horseweed & $\mathbf{A}$ & $\mathbf{N}$ & & & & $\mathbf{x}$ & & & $\mathbf{x}$ & \\
\hline Erigeron divergens & fleabane daisy & B & $\mathbf{N}$ & $\mathbf{x}$ & & & $\mathbf{x}$ & $\mathbf{x}$ & & & $\mathbf{x}$ \\
\hline Erigeron Jlagellaris & $\begin{array}{l}\text { trailing flea } \\
\text { bane daisy }\end{array}$ & B & $\mathbf{N}$ & & & & $\mathbf{x}$ & $\mathbf{x}$ & & & $\mathbf{x}$ \\
\hline Franseria spp. & bursage & $\mathbf{A}$ & $\mathbf{N}$ & & & & & & $\mathbf{x}$ & & \\
\hline Grindelia aphanactis & gumweed & B & $\mathbf{N}$ & $\mathbf{x}$ & $\mathrm{x}$ & & $\mathbf{x}$ & $\mathbf{x}$ & & $\mathbf{x}$ & \\
\hline Gutterrezia microcephala & snakeweed & $\mathbf{P}$ & $\mathbf{N}$ & $\mathbf{x}$ & $\mathbf{x}$ & $\mathbf{x}$ & & & $\mathbf{x}$ & $\mathbf{x}$ & $\mathbf{x}$ \\
\hline Haplopappus spinulosus & spiny goldenweed & $\mathbf{P}$ & $\mathbf{N}$ & & & $\mathbf{x}$ & & & & & \\
\hline Helianthus petiolaris & prairie sunflower & $\mathbf{A}$ & $\mathbf{N}$ & & & & & & & $\mathbf{x}$ & \\
\hline Hymenopappus fllfolius & yellow ragweed & $\mathbf{P}$ & $\mathbf{N}$ & $\mathrm{x}$ & & $x$ & & & & & \\
\hline Hymenoxys argentea & bitterweed & $\mathbf{P}$ & $\mathbf{N}$ & $\mathbf{x}$ & & & & & & & \\
\hline Hymenoxys richardsonii & pingue & $\mathbf{P}$ & $\mathbf{N}$ & $\mathbf{x}$ & & & $\mathbf{x}$ & $\mathbf{x}$ & & & $\mathrm{x}$ \\
\hline Gaillardia pulchella & gaillardia & $\mathbf{P}$ & $\mathbf{N}$ & & & & & & $\mathbf{x}$ & $\mathbf{x}$ & \\
\hline Kuhnia chlorolepis & false bonset & $\mathbf{P}$ & $\mathbf{N}$ & & $\mathbf{x}$ & $\mathbf{x}$ & & & & & \\
\hline Lactuca serriola & prickly lettuce & A & I & $\mathbf{x}$ & $x$ & & & & & & \\
\hline Liatris punctata & gayfeather & $\mathbf{P}$ & $\mathbf{N}$ & & & & & $\mathbf{x}$ & & & \\
\hline Senecio fendleri & Fendler's groundsel & $\mathbf{P}$ & $\mathbf{N}$ & $\mathbf{x}$ & & & & $\mathbf{x}$ & & & \\
\hline Senecio multicapitatus & groundsel & $\dot{\mathbf{P}}$ & $\mathbf{N}$ & & & & & & $\mathbf{x}$ & & \\
\hline Solidago spp. & goldenrod & $\mathbf{P}$ & $\mathbf{N}$ & & & & & $\mathbf{x}$ & & & \\
\hline
\end{tabular}




\begin{tabular}{|c|c|c|c|c|c|c|c|c|c|c|c|}
\hline Species & Common Name & Habit & Origin & $\underline{\mathbf{B}}$ & $\underline{\mathbf{C}}$ & $\underline{\mathbf{E}}$ & $\mathbf{F a}$ & $\underline{F b}$ & $\underline{\mathbf{G}_{1}}$ & $\underline{\mathbf{G}_{3}}$ & $\begin{array}{c}\text { Experimental } \\
\text { Wate } \\
\text { Site } \\
\end{array}$ \\
\hline Tetradymia canescens & horsebush & $\mathbf{s}$ & $\mathbf{N}$ & & & $\mathbf{x}$ & & & & & \\
\hline Townsendia escapa & Easter daisy & $\mathbf{P}$ & $\mathbf{N}$ & $\mathbf{x}$ & & & & & & & \\
\hline Tragopogon dubius & goats beard & $\mathbf{A}$ & 1 & $\mathbf{x}$ & & $\mathbf{x}$ & $\mathbf{x}$ & & & & \\
\hline Taraxacum officinale & dandelion & $\mathbf{P}$ & 1 & $\mathbf{x}$ & & & & $\mathbf{x}$ & & & \\
\hline Thelesperma trifidum & greenthread & $\mathbf{P}$ & $\mathbf{N}$ & $\mathbf{x}$ & & $\mathbf{x}$ & $\mathbf{x}$ & & & & $\mathbf{x}$ \\
\hline CRUCIFERAE & mustard family & & & & & & & & & & \\
\hline Descurainia richardsonii & tansy mustard & & & $\mathbf{x}$ & & & $\mathbf{x}$ & & & & \\
\hline Sisymbrtum. spp. & tumble mustard & $\mathbf{A}$ & $\mathbf{N}$ & $\mathbf{x}$ & & & & & & & \\
\hline CUPRESSACEAE & juniper family & & & & & & & & & & \\
\hline Juniperus monosperma & one-seed juniper & $\mathbf{T}$ & $\mathbf{N}$ & $\mathbf{x}$ & $\mathbf{x}$ & $\mathbf{x}$ & $\mathbf{x}$ & $\mathbf{x}$ & & & \\
\hline EUPHORBIACEAE & spurge family & & & & & & & & & & \\
\hline Euphorbia spp. & spurge & & & & & & & & & $\mathbf{x}$ & \\
\hline FAGACEAE & beech family & & & & & & & & & & \\
\hline Quercus gambelii & Gambel's oak & $\mathbf{S}$ & $\mathbf{N}$ & $\mathbf{x}$ & & & & & & & $\mathbf{x}$ \\
\hline GERANIACEAE & Beranium family & & & & & & & & & & \\
\hline Geranium caespitosum & James' geranium & $\mathbf{P}$ & $\mathbf{N}$ & $x$ & $\mathbf{x}$ & & & & & & \\
\hline Erodium cicutarium & Crane's bill & $\mathbf{A}$ & I & $\mathbf{x}$ & & & & & & $\mathbf{x}$ & \\
\hline GRAMINAE & grass family & & & & & & & & & & \\
\hline Agropyron spp. & wheatgrass & $\mathbf{P}$ & $\mathbf{N}$ & & & & & & & $\mathbf{x}$ & \\
\hline Andropogon scoparius & little blue stem & $\mathbf{P}$ & $\mathbf{N}$ & $\mathbf{x}$ & $\mathbf{x}$ & & $x$ & $\mathbf{x}$ & & & \\
\hline Aristida dlvaricata & poverty 3-awil & $\mathbf{P}$ & $\mathbf{N}$ & $\mathbf{x}$ & $\mathbf{x}$ & $\mathbf{x}$ & $\mathbf{x}$ & $\mathbf{x}$ & $x$ & & \\
\hline Blepharoneuron tricholepis & pine dropseed & $\mathbf{P}$ & $\mathbf{N}$ & $\mathbf{x}$ & & & & $\mathbf{x}$ & & & \\
\hline Boutelova curtipendula & sideoats grama & $\mathbf{P}$ & $\mathbf{N}$ & & & & & & & $\mathbf{x}$ & \\
\hline
\end{tabular}




\begin{tabular}{|c|c|c|c|c|c|c|c|c|c|c|c|}
\hline Species & Common Name & Habit & Origin & $\underline{\mathbf{B}}$ & $\underline{\mathbf{C}}$ & $\underline{\mathbf{E}}$ & $\underline{\mathbf{F} \mathbf{a}}$ & Fb & $\underline{\mathbf{G}_{1}}$ & $\underline{\mathbf{G}_{3}}$ & $\begin{array}{c}\text { Experimentul } \\
\text { Waste } \\
\text { Site } \\
\end{array}$ \\
\hline Bouteloua gracilis & blue grama & $\mathbf{P}$ & $\mathbf{N}$ & $\mathbf{x}$ & $\mathbf{x}$ & $\mathbf{x}$ & & $\mathrm{x}$ & & $\mathbf{x}$ & $\mathbf{x}$ \\
\hline Bromus spp. & brome & $\mathbf{A}$ & I & $\mathbf{x}$ & & & & & & & \\
\hline Bromus tectorum & downy chess & $\mathbf{A}$ & $\mathbf{I}$ & $\mathbf{x}$ & $\mathbf{x}$ & & $\mathrm{x}$ & & & $\mathbf{x}$ & \\
\hline Buchloe dactyloides & buffalo grass & & & & & & & & $\mathbf{x}$ & & \\
\hline Festuca spp. & Pescue & $\mathbf{P}$ & $\mathbf{N}$ & $\mathbf{x}$ & & & & & & $\mathbf{x}$ & \\
\hline Hilaria jamesii & galleta & $\mathbf{P}$ & $\mathbf{N}$ & & & $\mathbf{x}$ & & & & & \\
\hline Koelaria cristata & June grass & $\mathbf{P}$ & $\mathbf{N}$ & & & & & & & & $\mathbf{x}$ \\
\hline Muhlenbergia montana & mountain muhly & $\mathbf{P}$ & $\mathbf{N}$ & $\mathbf{x}$ & $\mathbf{x}$ & & $\mathbf{x}$ & $\mathbf{x}$ & & $\mathbf{x}$ & \\
\hline Oryzopsis hymenoides & rice grass & $\mathbf{P}$ & $\mathbf{N}$ & $\mathbf{x}$ & & $\mathbf{x}$ & & $x$ & $\mathbf{x}$ & & \\
\hline Poa spp. & blue grass & $\mathbf{P}$ & $\mathbf{N}$ & $\mathbf{x}$ & $\mathbf{x}$ & & & & & & \\
\hline Sitanion hystrix & squirrel tail & $\mathbf{P}$ & $\mathbf{N}$ & $\mathbf{x}$ & $\mathbf{x}$ & $\mathbf{x}$ & $\mathbf{x}$ & $\mathbf{x}$ & & $\mathbf{x}$ & $\mathbf{x}$ \\
\hline Sporobolus cryptandrus & sand dropseed & $\mathbf{P}$ & $\mathbf{N}$ & $\mathbf{x}$ & $\mathbf{x}$ & $\mathbf{x}$ & & $\mathbf{x}$ & & $\mathbf{x}$ & \\
\hline Stipa comata & needlegrass & $\mathbf{P}$ & $\mathbf{N}$ & $\mathbf{x}$ & & $x$ & & & $\mathrm{x}$ & & \\
\hline LEGUMINOSAE & pea family & & & & & & & & & & \\
\hline Medicago sativa & alfalfa & $\mathbf{P}$ & I & $\mathbf{x}$ & & & & $x$ & & $\mathbf{x}$ & \\
\hline Melilotus spp. & sweet clover & B & I & $\mathbf{x}$ & $\mathbf{x}$ & $\mathbf{x}$ & $\mathbf{x}$ & $\mathrm{x}$ & & $x$ & $\mathbf{x}$ \\
\hline Petalostemum candidum & prairie clover & $\mathbf{P}$ & $\mathbf{N}$ & & & & $\mathbf{x}$ & $x$ & & & \\
\hline Robinia neomexicana & New Mexico locust & $\mathbf{s}$ & $\mathbf{N}$ & & $\mathbf{x}$ & & & & & & \\
\hline Vicia americana & American vetch & $\mathbf{P}$ & $\mathbf{N}$ & & & & & $\mathbf{x}$ & & & \\
\hline Lotus wrightii & deer vetch & $\mathbf{P}$ & $\mathbf{N}$ & & & & $x$ & & & & \\
\hline LILIACEAE & lily family & & & & & & & & & & \\
\hline Yucca angustissima & yucca & $\mathbf{P}$ & $\mathbf{N}$ & $\mathbf{x}$ & & & & & & & $\mathbf{x}$ \\
\hline LNACEAE & flax family & & & & & & & & & & \\
\hline Limum neomexicanum & New Mexico flax & $\mathrm{A} / \mathrm{B}$ & $\mathbf{N}$ & & & & $\mathbf{x}$ & $\mathbf{x}$ & & & \\
\hline LOACEAE & bløing star family & & & & & & & & & & \\
\hline Mentzelia pumila & blazing star & B & $\mathbf{N}$ & & $\mathbf{x}$ & & & & $\mathbf{x}$ & & \\
\hline
\end{tabular}




\begin{tabular}{|c|c|c|c|c|c|c|c|c|c|c|c|}
\hline Species & Common Name & Habit & Origin & $\underline{\mathbf{B}}$ & C & $\underline{E}$ & $\mathbf{F a}$ & Fb & $\mathbf{G}_{1}$ & $\mathbf{G}_{3}$ & $\begin{array}{c}\text { Buperimentel } \\
\text { Wente } \\
\text { Site }\end{array}$ \\
\hline $\begin{array}{l}\text { MALVACEAE } \\
\text { Sphaeralcea spp. }\end{array}$ & $\begin{array}{l}\text { mallow family } \\
\text { globe mallow }\end{array}$ & $\mathbf{P}$ & $\mathbf{N}$ & & $\mathbf{x}$ & & & & & & \\
\hline $\begin{array}{l}\text { ONAGRACEAE } \\
\text { Oenothera spp. } \\
\text { Goura coccinea }\end{array}$ & $\begin{array}{l}\text { esening primrose family } \\
\text { evening primrose } \\
\text { scarlet guara }\end{array}$ & B & $\mathbf{N}$ & $\begin{array}{l}\mathbf{x} \\
\mathbf{x}\end{array}$ & $\mathbf{x}$ & & $\mathbf{x}$ & $\mathbf{x}$ & & & \\
\hline $\begin{array}{l}\text { PINACEAE } \\
\text { Pinus edulis } \\
\text { Pinus ponderosa }\end{array}$ & $\begin{array}{l}\text { pine family } \\
\text { piñon pine } \\
\text { ponderosa pine }\end{array}$ & $\begin{array}{l}\mathbf{T} \\
\mathbf{T}\end{array}$ & $\begin{array}{l}\mathbf{N} \\
\mathbf{N}\end{array}$ & $\mathbf{x}$ & & $\mathbf{x}$ & $\mathbf{x}$ & $\mathbf{x}$ & $\mathbf{x}$ & & $\mathbf{x}$ \\
\hline $\begin{array}{l}\text { PLANTAGINACEAE } \\
\text { Plantago purshti }\end{array}$ & $\begin{array}{l}\text { phantago family } \\
\text { woolly Indian wheat }\end{array}$ & $\mathbf{A}$ & $\mathbf{N}$ & $x$ & $\mathbf{x}$ & & $\mathbf{x}$ & $\mathbf{x}$ & & & \\
\hline $\begin{array}{l}\text { POLEMONIACEAE } \\
\text { Ipomopsis longiflora }\end{array}$ & $\begin{array}{l}\text { phlox family } \\
\text { blue gilia }\end{array}$ & $\mathbf{A}$ & $\mathbf{N}$ & & & & & & & $\mathbf{x}$ & \\
\hline $\begin{array}{l}\text { POLYGONACEAE } \\
\text { Eriogonum spp. } \\
\text { Eriogonum cernuum }\end{array}$ & $\begin{array}{l}\text { buckwheat family } \\
\text { buckwheat } \\
\text { nodding buckwheat }\end{array}$ & $\begin{array}{l}\mathbf{P} \\
\mathbf{A}\end{array}$ & $\begin{array}{l}\mathbf{N} \\
\mathbf{N}\end{array}$ & $\mathbf{x}$ & & & & & $\mathbf{x}$ & & $\mathbf{x}$ \\
\hline $\begin{array}{l}\text { ROSACEAE } \\
\text { Cercocarpus montanus } \\
\text { Fallugia paradoxa }\end{array}$ & $\begin{array}{l}\text { rose farnily } \\
\text { mountain mahogany } \\
\text { Apache plume }\end{array}$ & $\begin{array}{l}\mathbf{S} \\
\mathbf{S}\end{array}$ & $\begin{array}{l}\mathbf{P} \\
\mathbf{P}\end{array}$ & $\begin{array}{l}\mathbf{x} \\
\mathbf{x}\end{array}$ & & & & & & & $\begin{array}{l}x \\
x\end{array}$ \\
\hline Potentilla spp. & $\begin{array}{l}\text { Apacne plume } \\
\text { cinquefoil }\end{array}$ & $\mathbf{P}$ & $\mathbf{N}$ & $\mathbf{x}$ & & $\mathbf{x}$ & & $\mathbf{x}$ & $\mathbf{x}$ & & \\
\hline $\begin{array}{l}\text { Rosa woodsil } \\
\text { Prumus persica }\end{array}$ & $\begin{array}{l}\text { wild rose } \\
\text { peach }\end{array}$ & $\begin{array}{l}\mathbf{S} \\
\mathbf{T}\end{array}$ & $\begin{array}{c}\mathbf{N} \\
\mathbf{I}\end{array}$ & $\mathbf{x}$ & $x$ & & & $\mathbf{x}$ & & & . \\
\hline $\begin{array}{l}\text { SAXIFRAGACEAE } \\
\text { Rlbes cereum }\end{array}$ & $\begin{array}{l}\text { saxifrage family } \\
\text { gooseberry }\end{array}$ & $\mathbf{s}$ & $\mathbf{N}$ & & & & & & & & $\mathbf{x}$ \\
\hline
\end{tabular}


APPENDIX B (cont)

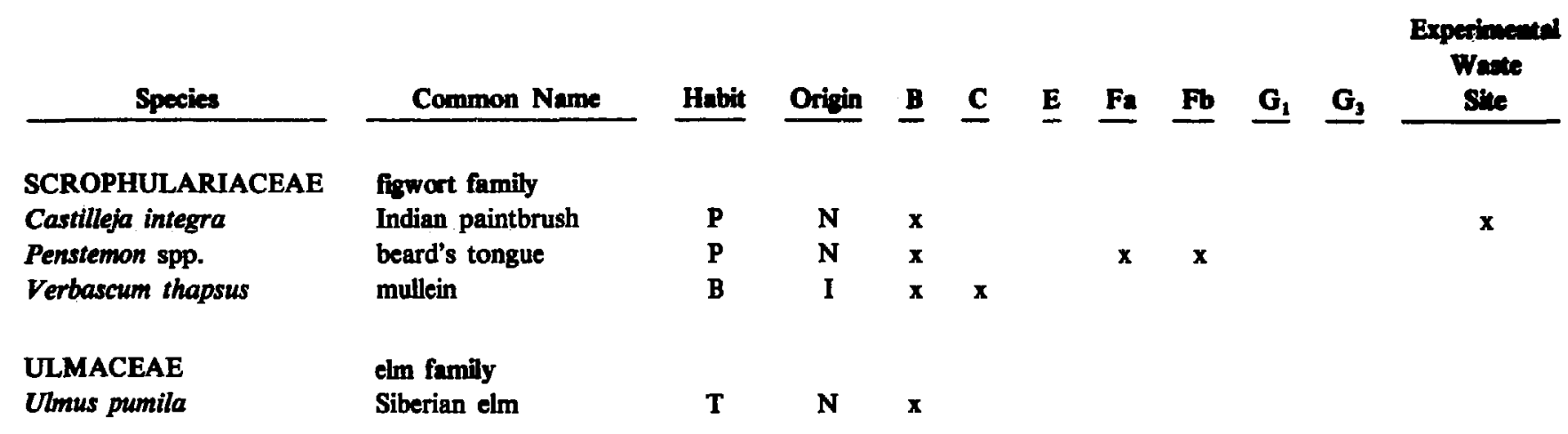




\section{APPENDIX C \\ LETTER AND LISTING OF PLANTS FOUND ON EXPERMMENTAL ENGINEERED WASTE DISPOSAL SITE}

412 Rover

Los Alamos, N. M. 87544

December 1, 1980

Gerald DePoorter

LS-6

Los Alamos Scientific Laboratory

Los Alamos, New Mexico 87544

Dear Jerry,

On October 28, 1980, I surveyed areas which you have designated for waste disposal experiments. At your request I paid particular attention to any endangered plant species which might be found in the area. The only species of concern was Pediocactus papyracanthus (grama grass cactus) as discussed in our report "Status of the Flora of the Los Alamos National Environmental Research Park." I did not find this species on your site or any other species which I deem as rare, endangered, or threatened.

I have enclosed a list of species which were noted on the site for your future reference. Cover percentages would best be done when vegetation is not dormant. If at a later date you would like further information as to cover percentages or mapping of specific sites, Gail and I would be glad to comply.

Sincerely,

Teralene S. Foxx

LASL consultant

Research Botanist 


\title{
VASCULAR PLANT SPECIES FOUND ON WASTE DISPOSAL RESEARCH SITE AS OF OCTOBER 28, 1980
}

\author{
Teralene S. Foxx.
}

This site is located off Pajarito Road and is within the piñon-juniper plant community. The area is dominated by piñon (Pinus edulis) and one-seed juniper (Juniperus monosperma). Understory vegetation is enumerated below. In most areas, blue grama (Boutelous gracilis) makes up 25 to $50 \%$ of the total cover. The most common forb species are snakeweed (Gutierrezia spp.), pinque (Hymenoxys richardsonii), and wormwood (Artemisia carruthii). The former two species are indicative of past overgrazing.

The area wp,s walked over October 28, 1980, and all species were recorded and noted as to dominance. In the following list, each plant is ranked as to dominance in occular cover estimates, " 5 " having the greatest cover percentages and " 1 " the least. This is a generalization for the entire area. Specific cover estimates would be better done when vegetation is not dormant.

Grasses or Grasslike Plants

\begin{tabular}{|c|c|c|c|}
\hline Common Name & Scientific Name & Ranking & Habit \\
\hline blue grama & $\begin{array}{c}\text { Bouteloua gracilis } \\
\text { (H.B.K.) Lag. }\end{array}$ & 5 & perennial \\
\hline june grass & $\begin{array}{l}\text { Koelaria cristata } \\
\text { (L.) (Pers.) }\end{array}$ & 1 & perennial \\
\hline squirreltail & $\begin{array}{l}\text { Sitanion hystrix } \\
\text { (Nutt.) J. G. Smith }\end{array}$ & 1 & perennial \\
\hline unknown grass & $\begin{array}{l}\text { There was one grass not } \\
\text { identifiable at this time } \\
\text { of year, probably Festuca } \\
\text { spp. }\end{array}$ & & \\
\hline \multicolumn{4}{|c|}{ Forbs } \\
\hline wormwood, & $\begin{array}{l}\text { Artemisia carruthti } \\
\text { Wood }\end{array}$ & 3 & perennial \\
\hline false terragon & $\begin{array}{l}\text { Artemisia dracunculus } \\
\text { Pursh }\end{array}$ & 1 & perennial \\
\hline wormwood & $\begin{array}{l}\text { Artemisia ludoviciana } \\
\text { Nutt. }\end{array}$ & 1 & perennial \\
\hline yellow ragweed & $\begin{array}{l}\text { Bahia dissecta } \\
\text { (Gray) Britt. }\end{array}$ & 1 & biennial \\
\hline Indian paintbrush & $\begin{array}{l}\text { Castilleja integra } \\
\text { Gray }\end{array}$ & 1 & perennial \\
\hline hiddenflower & $\begin{array}{l}\text { Cryptantha jamesil } \\
\text { (Torr.) Payson }\end{array}$ & 1 & perennial \\
\hline spreading fleabane & $\begin{array}{l}\text { Erigeron divergens } \\
\text { Torr. \& Gray }\end{array}$ & 2 & biennial \\
\hline
\end{tabular}




\section{Forbs (Cont)}

\begin{tabular}{|c|c|c|c|}
\hline Common Name & Scientific Name & Ranking & Habit \\
\hline trailing fleabane & $\begin{array}{l}\text { Erigeron flagellaris } \\
\text { Gray }\end{array}$ & $1-2$ & biennial \\
\hline winged wild buckwheat & $\begin{array}{l}\text { Eriogonum alatum } \\
\text { Torr. }\end{array}$ & 1 & porennial \\
\hline pinque, bitterweed & $\begin{array}{l}\text { Hymenoxys richardsonii } \\
\text { (Hook.) Cockll. }\end{array}$ & 3 & perennial \\
\hline deervetch & $\begin{array}{l}\text { Lotus wrightii } \\
\text { (Gray) Greene }\end{array}$ & 1 & perennial \\
\hline sweetclover & Melilotus spp. & 1 & annual \\
\hline prickly pear & Opuntia spp. & $1-2$ & perennial \\
\hline walking stick cactus & $\begin{array}{l}\text { Opuntia imbricata } \\
\text { (Haw.) DC. } \\
\text { (generally small and } \\
\text { immature) }\end{array}$ & 1 & perennial \\
\hline greenthread & $\begin{array}{l}\text { Thelesperma trifidum } \\
\text { (Poir.) Britt. }\end{array}$ & 1 & perennial \\
\hline \multirow[t]{2}{*}{ pincushion cactus } & $\begin{array}{l}\text { I am not sure of this } \\
\text { species but it is probably } \\
\text { Coryphantha pivipara. Need } \\
\text { to collect at blooming. }\end{array}$ & 1 & perennial \\
\hline & Shrubs or Subshrubs & & \\
\hline Estafiata & $\begin{array}{l}\text { Artemisia frigida } \\
\text { Willd. }\end{array}$ & 2 & subshrub \\
\hline mountain mahogany & $\begin{array}{l}\text { Cercocarpus montanus } \\
\text { Raf. }\end{array}$ & 1 & \\
\hline rabbitbrush/chamisa & Chrysothamnus nauseosus & 1 & \\
\hline Apache plume & Fallugia paradoxa & 1 & \\
\hline snakeweed & Gutierrezia spp. & 3 & \\
\hline Gambel oak & $\begin{array}{l}\text { Quercus gambellii } \\
\text { Nutt. }\end{array}$ & 1 & \\
\hline wax currant & $\begin{array}{l}\text { Ribes cereum } \\
\text { Doug. }\end{array}$ & 1 & \\
\hline yucca & $\begin{array}{l}\text { Yucca angustissima } \\
\text { Engel. }\end{array}$ & $1-2$ & \\
\hline
\end{tabular}

